\title{
Mountain Systems
}

Coordinating Lead Authors: Christian Körner, Masahiko Ohsawa

Lead Authors: Eva Spehn, Erling Berge, Harald Bugmann, Brian Groombridge, Lawrence Hamilton, Thomas

Hofer, Jack Ives, Narpat Jodha, Bruno Messerli, Jane Pratt, Martin Price, Mel Reasoner, Alan Rodgers,

Jillian Thonell, Masatoshi Yoshino

Contributing Authors: Jill Baron, Roger Barry, Jules Blais, Ray Bradley, Robert Hofstede, Valerie Kapos, Peter

Leavitt, Russell Monson, Laszlo Nagy, David Schindler, Rolf Vinebrooke, Teiji Watanabe

Review Editors: Blair Fitzharris, Kedar Shrestha

Main Messages . . . . . . . . . . . . . . . . . . . . . 683

24.1 Introduction and Scope of Global Mountain Systems $\ldots \ldots \ldots \ldots 683$

24.1.1 Definitions of Mountains and Altitude Belts

24.1.2 Aerial Extent and Main Mountain Ranges

24.1.3 Biota

24.1.4 Social and Economic Conditions

24.2 Mountain Ecosystem Services 688

24.3 Condition and Trends of Mountain Systems 688

24.3.1 Atmospheric Conditions

24.3.2 Mountain Biota

24.3.3 Mountain Watersheds

24.3.4 Socioeconomy in Mountains

24.4 Drivers of Change in Mountain Systems $\ldots \ldots \ldots \ldots \ldots \ldots \ldots \ldots$

24.4.1 Direct Drivers

24.4.2 Indirect Drivers

24.4.3 Property Rights to Mountains

24.4.4 Wars and Other Conflicts

24.4.5 Mountain Protected Areas

24.5 Trade-offs, Synergies, and Management Interventions in Mountain Systems ................................. 709 24.5.1 Highland-Lowland Interactions and Their Trade-offs

24.5.2 Management and Interventions

24.6 Mountain Systems and Human Well-being $\ldots \ldots \ldots \ldots \ldots \ldots 711$

24.6.1 Sustainability

24.6.2 Vulnerability 


\section{BOXES}

24.1

Defining Mountains by Topography Only

24.2

24.3

24.4

24.5

24.6

Overutilization of Water from Mountain Areas Leading to Desertification

\section{FIGURES}

Floods, Landslides, and Reservoirs

An Institutional Definition of Property Rights

24.1-24.4 Mountains of the World

24.5 Mountains of the World Based on Topography Alone*

24.6 Classic Humboldt Profile of the Latitudinal Position of Altitude Belts in Mountains across the Globe and

Compression of Thermal Zones on Mountains, Altitude for Latitude

24.7 Montane Rainforest, Kilimanjaro at 2,600 Meters

24.8 Alpine Grassland in the North Argentinian Andes at 4,100 Meters

24.9 Snow and Rock Fields in the Nival Zone, in the Swiss Alps at 2,700 Meters

24.10 Mean Net Balance and Cumulative Mean Net Balance Continuously Measured for 1980-99 on 30 Glaciers in Nine Mountain Ranges

24.11 Potential Forest Life Zone Model Overlaid on Mountain Profile of Southeast to East Asia

24.12 Mean Contribution (Importance) in Percent of Mountain Catchments to the Total Discharge per River System

24.13 Example of the Ewaso Ng'iro River Catchment, Originating from the Slopes of Mount Kenya
24.14-24.17 Mountain People

24.18 A Typology of Mountain Economies

\section{TABLES}

24.1 Estimated Global Mountain Area by Continent Based on Topography Alone

24.2 Global Mountain Area Based on Broad Biomes, Using Different Classification Schemes

24.3 Altitudinal Distribution of Land Area and Forest Cover for World's Mountains

24.4 Ecosystem Services in Mountains

$24.5 \quad$ Land Cover in Mountains

24.6 Areas of Different Forest Types Occurring in Each Mountain Class

24.7 Main Mountain Farming Systems in Developing and Transition Countries: Location, Characteristics, Area, and Rural Population

24.8 Global Mountain Population Estimate and Share That Is Urban

24.9 Mountain Population by Region and Average Mountain Population Density

24.10 Global Mountain Population, Share That Is Urban, Population Density, Population Growth, and Infant Mortality Rate by Biogeographical Zone

24.11 The Six IUCN Management Categories of Protected Areas

24.12 Mountain Parks (High Mountains)

24.13 Vulnerable Rural Mountain People in Developing and Transition Countries by Mountain Area Class

^This appears in Appendix A at the end of this volume. 


\section{Main Messages}

Half of the human population depends on mountains. Defined by elevation above sea level (minimum between 300 and 1000 meters, depending on latitude), steepness of slope (at least $2^{\circ}$ over 25 kilometers, on the 30 arc-second grid), and excluding large plateaus, mountains occupy about one fifth of the terrestrial surface. Twenty percent (1.2 billion) of the world's human population lives in mountains or at their edges, and half of humankind depends in one way or the other on mountain resources (largely water).

Mountains are characterized by high biodiversity. Because of the compression of climatic life zones with altitude and small-scale habitat diversity caused by different topoclimates, mountain regions are commonly more diverse than lowlands and are thus of prime conservation value. They support about one quarter of terrestrial biodiversity, with nearly half of the world's biodiversity hot spots concentrated in mountains. Geographically fragmented mountains support a high ethnocultural diversity. For many societies, mountains have spiritual significance, and scenic landscapes and clean air make mountains target regions for recreation and tourism. Thirty-two percent of protected areas are in mountains $(9,345$ mountain protected areas covering about 1.7 million square kilometers).

Mountain ecosystems are exceptionally fragile. Mountains are subject to both natural and anthropogenic drivers of change. These range from volcanic and seismic events and flooding to global climate change and the loss of vegetation and soils because of inappropriate agricultural and forestry practices and extractive industries. Mountain biota are adapted to relatively narrow ranges of temperature (and hence altitude) and precipitation. Because of the sloping terrain and the relatively thin soils, the recovery of mountain ecosystems from disturbances is typically slow or does not occur.

Human well-being depends on mountain resources. These ecosystems are particularly important for the provision of clean water, and their ecological integrity is key to the safety of settlements and transport routes. They harbor rich biodiversity and contribute substantially to global plant and animal production. All these services depend on slope stability and erosion control provided by a healthy vegetative cover. As "water towers," mountains supply water to nearly half the human population, including some regions far from mountains, and mountain agriculture provides subsistence for about half a billion people. Key mountain resources and services include water for hydroelectricity, flood control, mineral resources, timber, and medicinal plants. Mountain populations have evolved a high diversity of cultures, including languages, and traditional agricultural knowledge commonly promotes sustainable production systems. In many mountain areas, tourism is a special form of highland-lowland interaction and forms the backbone of regional as well as national economies.

In general, both poverty and ethnic diversity are higher in mountain regions, and people are often more vulnerable than people elsewhere. Ninety percent of the global mountain population of about 1.2 billion people lives in developing countries and countries in transition-with one third of these in China and half in the Asia-Pacific region. Some 90 million mountain people-and almost everyone living above 2500 meters-live in poverty and are considered especially vulnerable to food insecurity. Land use pressure puts mountain ecosystem integrity at risk in many parts of the world. Industrial use, forest destruction, overgrazing, and inappropriate cropping practices lead to irreversible losses of soil and ecosystem function, with increased environmental risks in both mountains and adjacent lowland areas.

Mountains often represent political borders, restrict transport to narrow corridors, and are refuges for minorities and political opposition. As such they are often focal areas of armed conflicts. Further conflicts arise from the commercial exploitation of natural resources, usually by outside interests, and from ambiguity regarding traditional land use rights. Profits from extractive industries in mountains are not systematically reinvested either in the management of upland resources or the provision of benefits to mountain communities. Both poverty and remoteness are responsible for poor medical care and education systems in many mountain regions.

Strengthened highland-lowland linkages improve sustainability for both upstream and downstream populations. Lowland-highland relationships, whether formal or informal, have the potential to pay for investments in protection and sustainable use of mountain resources. When full costs are taken into account, stewardship of upland resources generally yields greater and more sustainable economic returns both to the people living in the mountain areas and to the immediate downstream economies when compared with extractive activities. In many cases, the focal point of such interactions has been based on providing a sustainable and clean supply of water, the most important and increasingly limiting mountain resource. In steep terrain, more than anywhere else, catchment quality is intimately linked to ecosystem integrity and functioning. Thus environmental conservation and sustainable land use in the world's mountains are not only a necessary condition for sustainable local livelihoods, they are also key to human well-being for nearly half the world's population who live downstream and depend on mountain resources.

\subsection{Introduction and Scope of Global Mountain Systems}

Since its existence, the surface of Earth has always been subject to tectonic forces that with the action of gravity and the erosive power of water have shaped landscapes into mountains, hills, lowland forelands, and old tableland. (See Figures 24.1-24.4.) Mountains are very attractive to outsiders, but the physical conditions challenge those living in these regions. Of the approximately 1.2 billion mountain people worldwide (20\% of world population), only $8 \%$ inhabit places above 2,500 meters elevation. The key functions of mountains for humanity are frequently overlooked, such as the headwaters of river systems that supply nearly half of humanity with water. This chapter assesses the available knowledge on physical, biological, economic, and social conditions in the world's mountain areas and describes their likely future.

\subsubsection{Definitions of Mountains and Altitude Belts}

Since the transition from lowland plains to mountain terrain is usually gradual, the definition of mountains is based on convention. For the purpose of this assessment, inclusive rather than selective criteria were adopted to define the mountain system. The three major problems that needed to be resolved were latitudinal differences in climate from the equator to the poles and thus the variable altitude of different life zones (hill, montane, alpine, nival); the relative importance of elevation versus slope (high altitude plains versus steep slopes of lowland hills, for example); and, tied to both these, the definition of the lower limit for mountain terrain. For practical reasons, local climatic and topographic peculiarities could not be accommodated.

One common definition (and the one adopted by the United Nations Environment Programme World Conservation Monitoring Centre) is a lower limit of 300 meters (Kapos et al. 2000). (See Box 24.1 here and Figure 24.5 in Appendix A.) Alternatively, the lower limit has been set at 1,000 meters at the equator (the upper limit of many tropical plant species including the coconut palm), gradually decreasing to about 300 meters at the $65^{\circ}$ northern and $55^{\circ}$ southern latitude, reaching sea level at a short distance beyond 

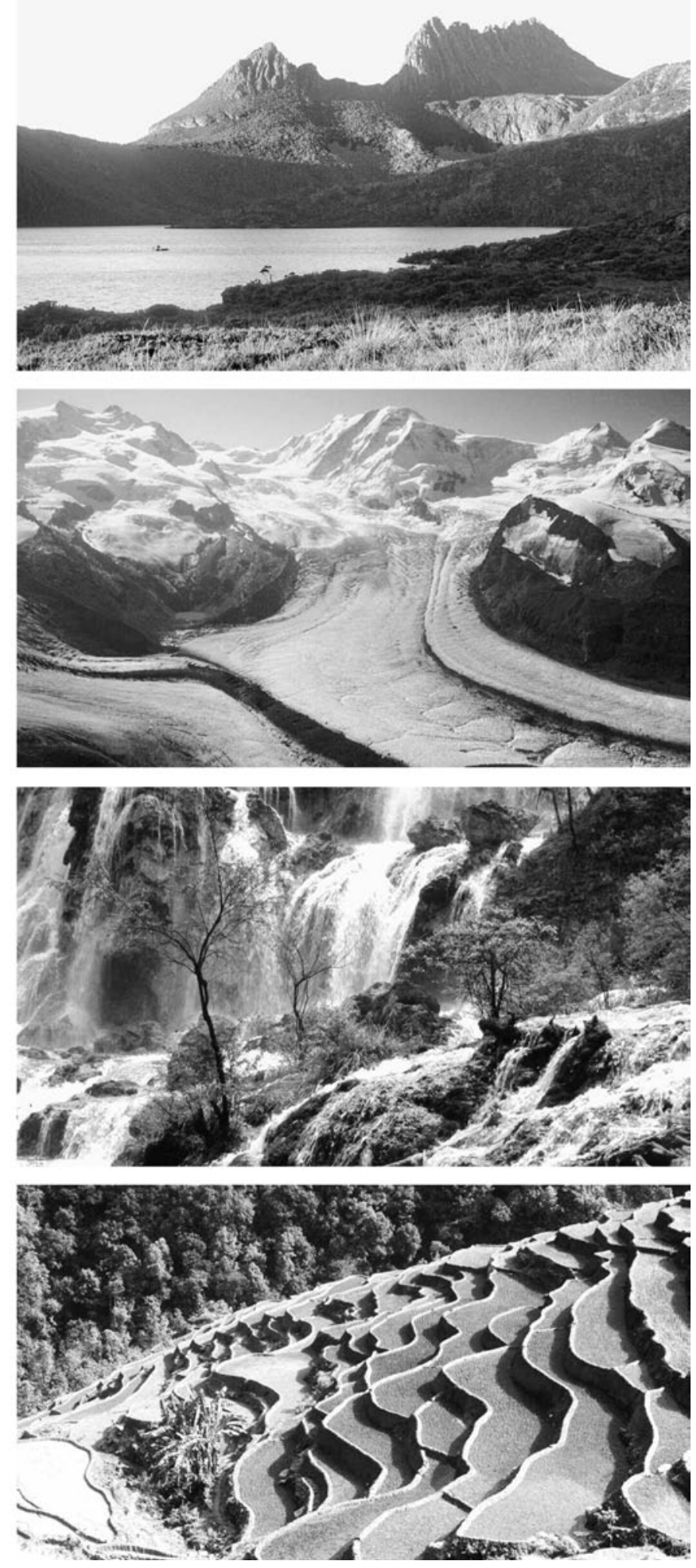

Figures 24.1-4. Mountains of the World. From top to bottom: Cradle Mountains, Tasmania, at 1,100 meters; Monte Rosa Glacier near Matterhorn, Switzerland, in the Central Alps at 3,000 meters; World Heritage Site Sichuan, Northwest China; Paddy field slope agriculture and deciduous montane forest (background) near Kathmandu, Nepal, at 1,200 meters.

\section{BOX 24.1 \\ Defining Mountains by Topography Only}

Kapos et al. (2000) used criteria based on altitude and slope in combination to represent the world's mountain environments. Topographical data from the GTOPO30 global digital elevation model (USGS EROS Data Centre 1996) were used to generate slope and local elevation range on a 30 arc-second (about 1 kilometer) grid of the world. These parameters were combined with elevation to arrive at empirically derived definitions of six elevation classes. To reduce projection distortion in the original data set, analysis was based on continental subsets in equidistant conic projection. The global mountain area thus defined is almost 40 million square kilometers, or $27 \%$ of Earth's surface. Assuming a lower mountain boundary of 1,000 meters at the equator and a linear reduction of this boundary to 300 meters at $67^{\circ} \mathrm{N}$ and $55^{\circ} \mathrm{S}$ reduced the total "mountain" land area by 5.4 million square kilometers or $3.7 \%$ of the global land.

Class 1, elevation $>4,500$ meters

Class 2, elevation 3,500-4,500 meters

Class 3 , elevation 2,500-3,500 meters

Class 4, elevation 1,500-2,500 meters and slope $\geqq 2$

Class 5 , elevation $1,000-1,500$ meters and slope $\geqq 5$ or local elevation range ( 7 kilometer radius) $>300$ meters

Class 6 , elevation $300-1,000$ meters and local elevation range (7 kilometer radius) $>300$ meters outside $23^{\circ} \mathrm{N}-19^{\circ} \mathrm{S}$

Class 7 , isolated inner basins and plateaus less than 25 square kilometers in extent that are surrounded by mountains but do not themselves meet criteria 1-6 (this seventh class was introduced in the 2002 revision of the original 2000 system)

these latitudes, where the alpine merges with the polar life zones. Ideally, however, the lower mountain limit should be defined climatically, irrespective of latitude. But this would require a world topoclimate map, which is currently not available.

The choice of convention is important because it has a large influence on the global mountain area. The UNEP-WCMC definition gives the global mountain area at about $23 \%$, whereas under the second definition it accounts for about 19\% of the global land area. For this review, flat terrain (basins or plateaus) below 2,500 meters elevation was excluded if the aerial extent of such plains exceeded 25 square kilometers. In essence, the definition used here followed that by Kapos et al. (2000).

In this global assessment, three belts were distinguished for mountain regions where precipitation regimes allow forest growth. In treeless arid or semiarid regions, analogues to these belts can be defined. (See Figure 24.6.)

- The montane belt (see Figure 24.7) extends from the lower mountain limit to the upper thermal limit of forest (irrespective of whether forest is present or not). This limit has a mean growing season temperature of $6.7+0.8^{\circ} \mathrm{C}$ globally, but is closer to $5.5^{\circ} \mathrm{C}$ near the equator and to $7.5^{\circ} \mathrm{C}$ at temperate latitudes. Between $40^{\circ} \mathrm{N}$ and $30^{\circ} \mathrm{S}$, this belt covers a range of 2,000-3,000 meters of elevation. Note the difference between mountain and montane.

- The alpine belt (see Figure 24.8) is the treeless region between the natural climatic forest limit and the snow line. The term "alpine" has many meanings, but here it refers strictly to a temperature-driven treeless high-altitude life zone that occurs worldwide and not solely in the European Alps (the term "alp" is of pre-Indo Germanic origin). Some synonyms such 


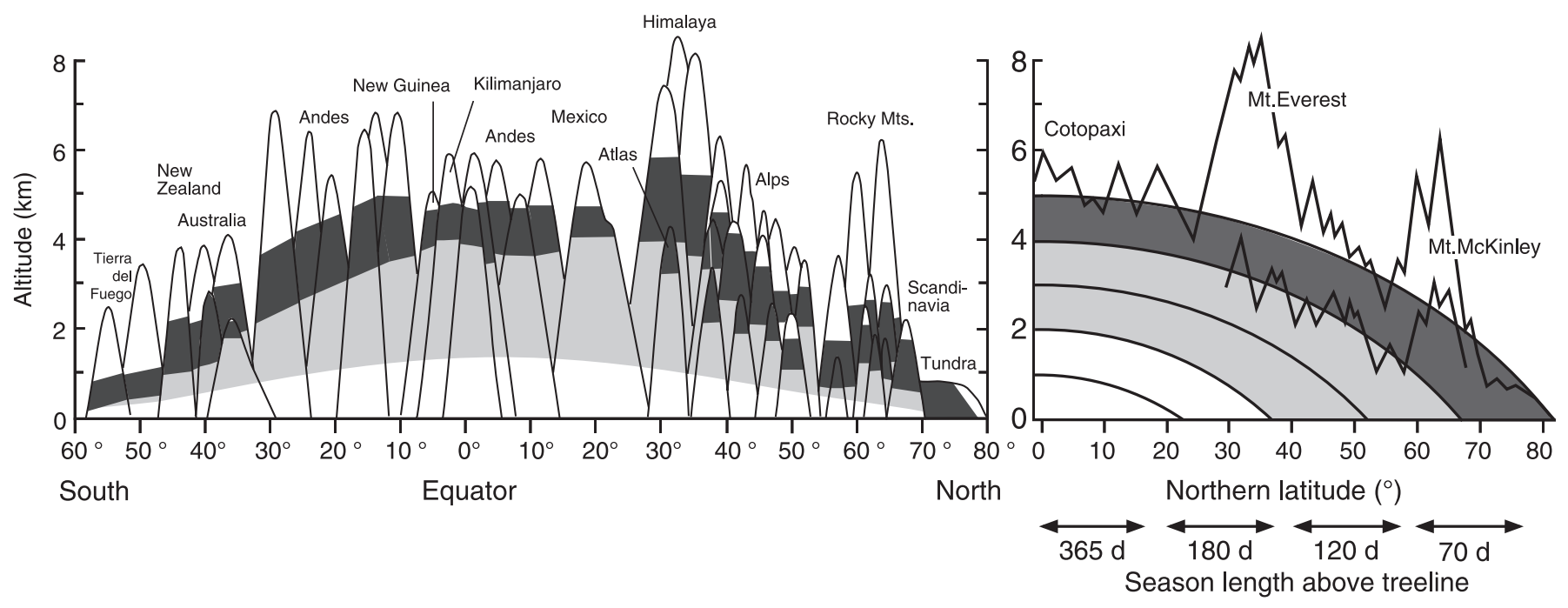

Figure 24.6. Classic Humboldt Profile of the Latitudinal Position of Altitude Belts in Mountains across the Globe and Compression of Thermal Zones on Mountains, Altitude for Latitude. Grey is montane; black is alpine; white is the nival belt. (Körner 2003)

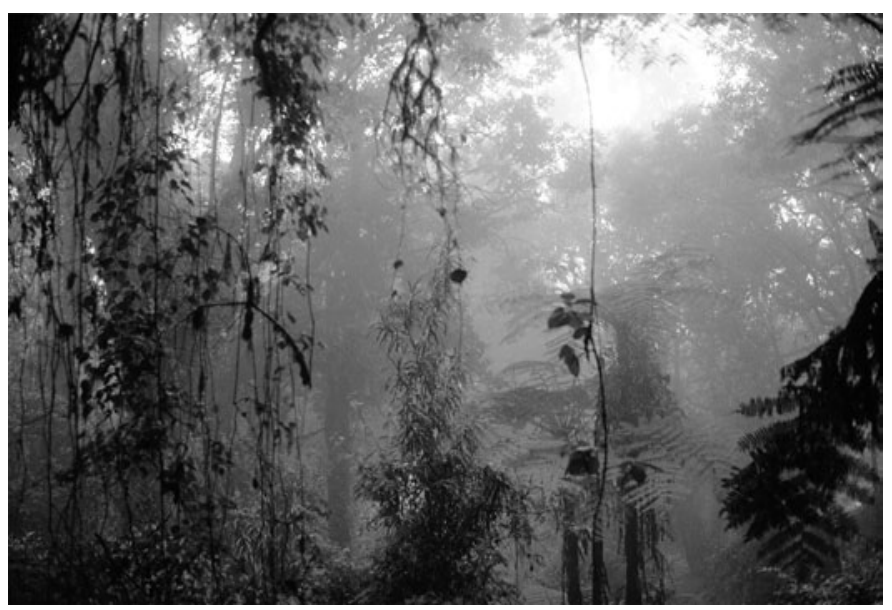

Figure 24.7. Montane Rainforest, Kilimanjaro, at 2,600 Meters

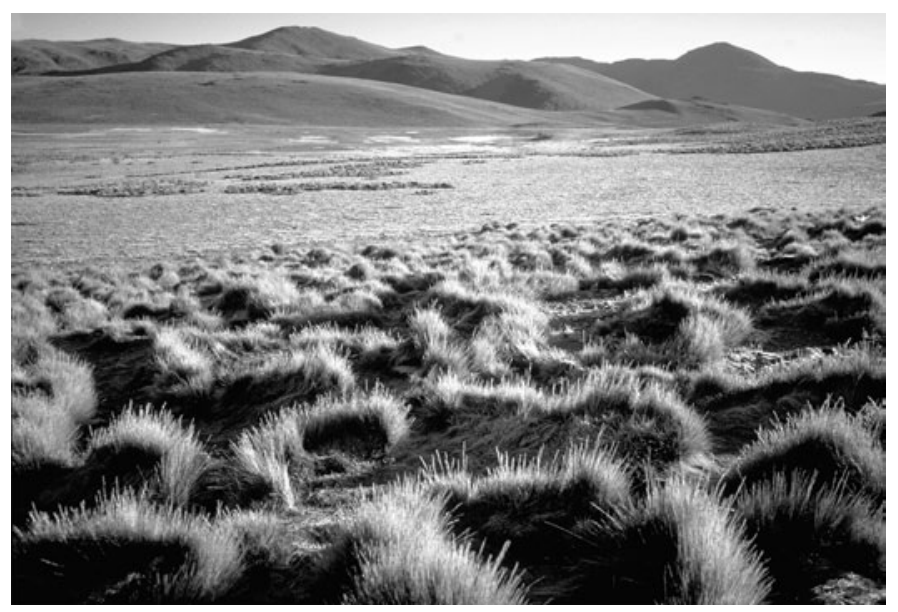

Figure 24.8. Alpine Grassland in the North Argentinean Andes at 4,100 Meters as "andean" and "afro-alpine" are in common scientific use. Land cover is dominated by grassland or low stature shrubland. Outside subpolar regions $\left(<60^{\circ} \mathrm{N},<50^{\circ} \mathrm{S}\right)$, the alpine belt extends over an elevation range of 800-1,200 meters, with its lower boundary varying from about 500-4,000 meters above sea level, depending on latitude.

- The nival belt (see Figure 24.9) is the terrain above the snowline, which is defined as the lowest elevation where snow is commonly present all year round (though not necessarily with full cover). While the lower part of the nival belt is still rich in living organisms, usually very little plant and animal life is found beyond 1,000-2,000 meters above the tree line, although animals and flowering plants can be found up to around 6,000 meters in some parts of the world.

The critical bioclimatic reference line that permits global comparison and "calibration" is the high elevation tree line. The thermal limit for forest growth is surprisingly consistent worldwide and holds as a reference for all mountains where moisture permits tree growth. It is important to note that this may not be a visible line in many mountains, because forests have been re-

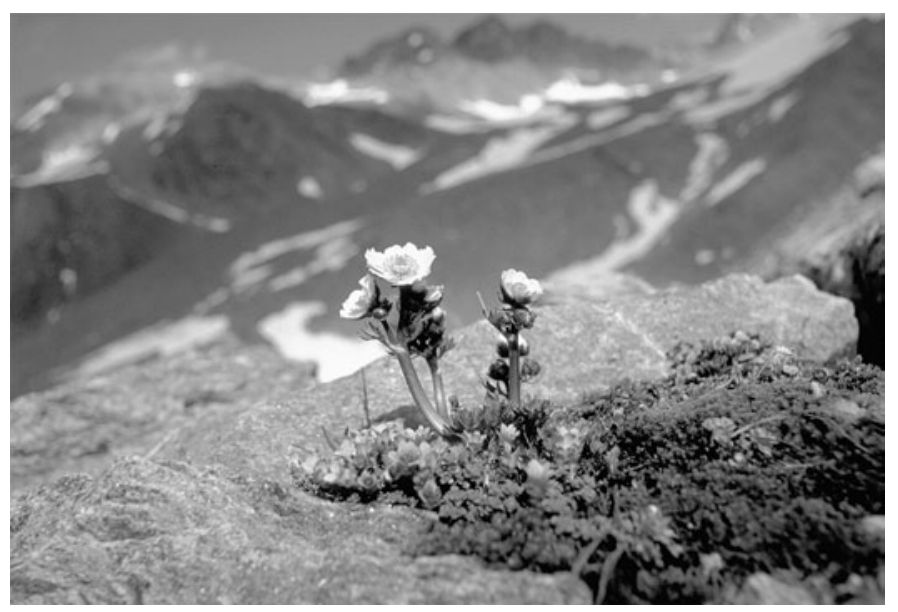

Figure 24.9. Snow and Rock Fields in the Nival Zone in the Swiss Alps at 2,700 Meters 
placed by pastures or cropland. These alternative land cover types are still categorized as "montane" when they occur below the thermal forest limit. Within the montane belt, different altitudespecific forest belts can be distinguished at lower latitudes, and the number of belts decreases toward higher latitudes. These belts are often referred to as lower-, mid-, and upper-montane.

\subsubsection{Aerial Extent and Main Mountain Ranges}

The Eurasian landmass has by far the largest mountain area of all continents; all of the world's mountains above 7,000 meters are in Asia, and all peaks above 8,000 meters are situated in the Greater Himalaya range. The Tibet (Qing Zang) Plateau is the most extensive inhabited land area above 2,500 meters elevation. Excluding Antarctica, South America has the second most extensive area of high elevation land, and the world's highest point outside Asia (Aconcagua, at 6,962 meters). Antarctica and Greenland also figure prominently, in part due to the extent and thickness of their icecaps.

Most of the world's mountain areas are found in the Northern Hemisphere and in temperate-sub-tropical latitudes (the Eurasian ranges and the North American cordilleras). (See Tables 24.1 and 24.2.) In addition, there are extensive mountain systems in the boreal (for example, Altai) and the subpolar (northeast Siberia, for instance) zones. In the Southern Hemisphere, the largest mountain systems are the Andes and the mountains of the Southeast Asian archipelago (such as New Guinea). Important but comparatively smaller mountain systems are also found in Africa, Australia, and New Zealand. More than a third of the montane belt is covered by forest, and perhaps as much as half could be potentially be covered by forest- that is, the cover is not limited by climate (see Table 24.3) - but has been converted to more open vegetation and agricultural lands by logging, fire, and grazing.
Slope, aspect, and altitude determine many of the fundamental characteristics of mountain environments. Gravity-driven topographic diversity adds significantly to the small-scale variation in life conditions. Geographic position such as latitude and distance from oceans affects climate and local weather patterns, making some mountains almost permanently wet, others dry, and some highly seasonal. Geological substratum adds a further dimension of geo-diversity and influences soil type and development, erosion processes, and vegetation cover.

Mountain climate shows a number of common features globally, but it can vary greatly regionally and locally. Several factors relevant to life processes change predictably with altitude and underlie the marked environmental gradients typical of high mountains. The most important common components are reduced pressure and reduced air temperature, with the associated reduction of water vapor pressure deficit. On average, temperature declines by $5.5 \mathrm{~K}$ per kilometer of elevation (but differs diurnally, seasonally, latitudinally, and from region to region), and air pressure (and with it, the partial pressures of oxygen and carbon dioxide) decreases by about $10 \%$ for every kilometer of elevation. Clear sky solar radiation increases with altitude, and higher maximum radiation and a greater short wave radiation (UV) are typical for higher elevations. However, clouds and fog may reverse altitudinal trends in solar radiation (Yoshino 1975; Barry 1992; Körner 2003).

Physical processes, in large part related to gravity, include erosion, landslides, mud flows, avalanches, and rockfall, and these determine life conditions in many parts of the world's mountains. At a more regional scale, volcanism and the associated sedimentation and slope processes affect biota and can have dramatic impact on people's life conditions. These physical phenomena of the mountain environment become enhanced when seismic activity comes into play, which is particularly the case in geologically

Table 24.1. Estimated Global Mountain Area by Continent Based on Topography Alone (Kapos et al. 2000)

\begin{tabular}{|c|c|c|c|c|c|c|c|}
\hline Region & $>4,500$ Meters & $\begin{array}{c}3,500-4,500 \\
\text { Meters }\end{array}$ & $\begin{array}{c}2,500-3,500 \\
\text { Meters }\end{array}$ & $\begin{array}{c}1,500-2,500 \\
\text { Meters and } \\
\text { Slope } \geq 2^{\circ}\end{array}$ & $\begin{array}{c}1,000-1,500 \\
\text { Meters and } \\
\text { Slope } \geq 5^{\circ} \text { or } \\
\text { Local Elevation } \\
\text { Range }>300 \\
\text { Meters }\end{array}$ & $\begin{array}{c}300-1,000 \\
\text { Meters and } \\
\text { Local } \\
\text { Elevation } \\
\text { Range }>300 \\
\text { Meters }\end{array}$ & $\begin{array}{c}\text { Total } \\
\text { Mountain } \\
\text { Area }\end{array}$ \\
\hline & \multicolumn{7}{|c|}{ (square kilometers) } \\
\hline North America & 197 & 11,417 & 200,830 & $1,092,881$ & $1,104,529$ & $1,840,140$ & $4,249,994$ \\
\hline Central America & 38 & 968 & 67,127 & 353,586 & 259,367 & 412,215 & $1,093,301$ \\
\hline Caribbean & & & 32 & 2,809 & 5,528 & 38,322 & 46,691 \\
\hline South America & 154,542 & 583,848 & 374,380 & 454,417 & 465,061 & 970,707 & $3,002,955$ \\
\hline Europe & & 225 & 497,886 & 145,838 & 345,255 & $1,222,104$ & $2,211,308$ \\
\hline Africa & 73 & 4,859 & 101,058 & 559,559 & 947,066 & $1,348,382$ & $2,960,997$ \\
\hline Middle East & 40,363 & 128,790 & 339,954 & 906,461 & 721,135 & 733,836 & $2,870,539$ \\
\hline Russian Federation & 31 & 1,122 & 31,360 & 360,503 & 947,368 & $2,961,976$ & $4,302,360$ \\
\hline Far East & $1,409,259$ & 741,876 & 627,342 & 895,837 & 683,221 & $1,329,942$ & $5,687,477$ \\
\hline Continental Southeast Asia & 170,445 & 107,974 & 97,754 & 211,425 & 330,574 & 931,217 & $1,849,389$ \\
\hline Insular Southeast Asia & 22 & 4,366 & 34,376 & 120,405 & 157,970 & 599,756 & 916,895 \\
\hline Australia & & & & 385 & 18,718 & 158,645 & 177,748 \\
\hline Oceania & & & 41 & 7,745 & 29,842 & 118,010 & 155,638 \\
\hline Antarctica & 17 & $1,119,112$ & $4,530,978$ & 165,674 & 144,524 & 327,840 & $6,288,145$ \\
\hline Total & $1,774,987$ & $2,704,557$ & $6,903,118$ & $5,277,525$ & $6,160,158$ & $12,993,092$ & $35,813,437$ \\
\hline
\end{tabular}


Table 24.2. Global Mountain Area Based on Broad Biomes in Mountains, Using Different Classification Schemes (FAO 2001; Holdridge 1967; Ramankutty and Foley 1999; Udvardy 1975; Olson et al. 2001)

\begin{tabular}{|c|c|c|c|c|c|c|c|c|c|c|}
\hline \multirow[b]{2}{*}{ Broad Mountain Biome } & \multicolumn{5}{|c|}{ Area } & \multicolumn{5}{|c|}{ Share of Total } \\
\hline & FAO & Holdridge & $\begin{array}{l}\text { Ramankutty } \\
\text { and Foley }\end{array}$ & Udvardy & Olson & FAO & Holdridge & $\begin{array}{l}\text { Ramankutty } \\
\text { and Foley }\end{array}$ & Udvardy & Olson \\
\hline & \multicolumn{5}{|c|}{ (thousand square kilometers) } & \multicolumn{5}{|c|}{ (percent) } \\
\hline Desert & 4,276 & 7,453 & 2,968 & 7,590 & 5,227 & 12.9 & 22.6 & 9.2 & 22.9 & 15.8 \\
\hline Forest and woodland & $8,159^{a}$ & 15,476 & 14,248 & 13,428 & 15,819 & 24.7 & 46.9 & 44.3 & 40.6 & 47.8 \\
\hline Grassland, savanna, steppe & 2,334 & 5,773 & 11,224 & 1,420 & 7,970 & 7.0 & 17.5 & 34.9 & 4.3 & 24.0 \\
\hline Mixed & 1,834 & 0 & 0 & 8,470 & 1,213 & 55.4 & 0.0 & 0.0 & 25.6 & 3.7 \\
\hline Treeless alpine & 0 & 4,291 & 3,729 & 2,206 & 2,899 & 0 & 13.0 & 11.6 & 6.7 & 8.8 \\
\hline Total & 33,104 & 32,993 & 32,168 & 33,113 & 33,128 & 100 & 100 & 100 & 100 & 100 \\
\hline
\end{tabular}

a The FAO mountain forest fraction is smaller because of a broadly defined "mixed land cover" category, which includes fragmented tree cover that is treated as forest in other statistics.

Table 24.3. Altitudinal Distribution of Land Area and Forest Cover for World's Mountains (Modified from Kapos et al. 2000)

\begin{tabular}{|c|c|c|c|c|c|}
\hline Elevation Class & $\begin{array}{c}\text { Global Land } \\
\text { Area }\end{array}$ & $\begin{array}{c}\text { Share of } \\
\text { Global Total }\end{array}$ & $\begin{array}{c}\text { Global Mountain } \\
\text { Area }\end{array}$ & $\begin{array}{c}\text { Share of } \\
\text { Global Land Area }\end{array}$ & $\begin{array}{l}\text { Mountain } \\
\text { Forest Area }\end{array}$ \\
\hline & (mill. sq. km) & (percent) & (mill. sq. km) & (percent) & (thousand sq. km) \\
\hline $3,500-4,500$ meters & 2.7 & 2.3 & 2.7 & 1.8 & 141.4 \\
\hline $2,500-3,500$ meters & 6.9 & 7.8 & 6.9 & 4.7 & 450.8 \\
\hline $300-1,000$ meters & 53.3 & 33.6 & 13.0 & 8.8 & $5,179.4$ \\
\hline 0-300 meters & 55.7 & 35.9 & 0.0 & 0.0 & 0 \\
\hline Total & 147.6 & 100.0 & 35.9 & 24.3 & $9,479.2$ \\
\hline
\end{tabular}

${ }^{a}$ In large fragmented elfin wood forests by Polylepis (Andes) and Juniperus (Himalayas).

young and thus steep mountains. Economic consequences and the death toll can be dramatic, as exemplified by catastrophic events in the recent history of Rwanda, the Philippines, Nepal, India, Italy, and the United States.

\subsubsection{Biota}

Vegetation on lower mountain slopes may be broadly similar to that of surrounding lowlands. However, environmental gradients linked with elevation typically lead to marked zonation. In less humid regions, the availability of moisture may at first increase with elevation. In drylands, this can allow tree growth on mountains that emerge from treeless semi-desert plains. In humid regions, epiphyte-rich evergreen cloud forest may occur above more seasonal forest. With further elevation, temperature decreases to a point where tree growth cannot be sustained. There is no common altitudinal trend of precipitation. In the temperate zone it commonly increases with altitude, but in the tropics it often decreases beyond a montane maximum, often leading to semi-deserts above 4,000 meters (such as in the altiplano in the Andes or the semiarid top of Kilimanjaro).

The altitudinal temperature gradient in mountains is about 600-1,000 times higher than the corresponding latitudinal gradient. Discernible vegetation belts on mountains may commonly span an elevation range of 1,000 meters. Over such a range, the temperature change is about $5-6 \mathrm{~K}$, enough to cause a full bioclimatic vegetation belt to be replaced by another (alpine by montane forest, for example). The latitudinal increase in seasonality and the annual temperature amplitude are mainly due to decreasing winter temperature, which limits the poleward extension of lower latitude species. Similarly, the colder climate of successive altitude belts restricts the growth of species from lower and warmer belts. One consequence of this is that ecosystems situated on mountain tops, with a species composition currently restricted by cold climate, are likely to disappear as a result of climate change.

Because of the compression of climatic zones along an elevation gradient, exposure effects, and large habitat diversity, species richness in mountains commonly exceeds that in the lowlands at small scales (such as hundred square meters). Within mountain regions, species richness decreases with increasing altitude, largely in proportion to the available land area (Körner 2000), but endemism often increases, due partly to topographic isolation (Gentry 1988; Peterson et al. 1993) and the often rapid formation and loss of links (corridors) in geological time.

Tree species diversity within a habitat commonly decreases with altitude; for example, in the tropical Andes there is an average decrease of nine species per 100 meters increase in altitude (Gentry 1988). Tropical mountain forests have 10 times higher species richness than temperate ones. Globally, there are some 
10,000 species of flowering plants in the alpine belt alonerepresenting about $4 \%$ of all known species and covering about $3 \%$ of the vegetated land area (Körner 1995). Some groups of organisms (amphibia, for example, and bryophytes) may reach their highest taxonomic diversity in the montane belt. Two types of endemism can be prominent in mountain areas: palaeo-endemism (the survival of evolutionary old taxa in isolated refugia, exemplified by Tertiary relics of primitive angiosperms of the genera $D a$ vidia, Tetracentron, Trochodendron in Southeast Asia) and neoendemism (more-recent speciation, for instance following the creation of new habitats due to volcanism or other major disturbances).

Thirty-two percent of all protected areas are located in mountainous regions, providing habitats for rare, relict, and endangered plants and animals (UNEP-WCMC 2002). Many species that survive in such refuges- pandas, tigers, takins, golden langurs, condors, and tapirs, for instance-are at risk from habitat fragmentation, however. Extended mountain ranges with continuous habitats provide a corridor for high altitude and cloud forest species, avoiding densely populated lowlands.

Ecological corridors that link isolated habitats are essential for many migrating species, which have extensive hunting or feeding territory requirements. Corridors can also facilitate species radiation, as shown for example in Espeletia, a giant rosette plant, in the Northern Cordilleras of the Andes (Cuatrecasas 1986). Connecting remote nature reserves, such corridors are effective tools to compensate for natural and human-induced fragmentation of habitats. Bhutan, for example, has nine protected areas covering $26 \%$ of the land (all in mountains), and all protected areas are linked by corridors, which cover another $9 \%$ of land area where land uses are compatible with conservation objectives (Dorji 2000).

\subsubsection{Social and Economic Conditions}

Twenty percent of the world's population-about 1.2 billion people-live in mountains. Most of them inhabit lower montane elevations, and almost half are concentrated in the Asia-Pacific region. Of the $8 \%$ living above 2,500 meters, almost all-about 90 million-live in poverty and are considered highly vulnerable to food insecurity. However, they have significant impact on larger populations living at lower elevations through their influence on catchments.

Low temperatures become prohibitive for people above 2,000 meters in temperate latitudes and above 3,500 meters in tropical latitudes (although there are exceptions up to $4,200 \mathrm{~m}$ ), and human activities rarely occur above 4,500 meters. Special efforts and techniques are required to sustain agricultural production at altitudes close to the upper tree line level.

There are many historical examples of flourishing mountain economies based on mountain ecosystem services (including Berbers, Afghan and Caucasian tribes, Tibetans, Mongolians, Highland Papuas, Incas, and Aztecs), and many of these cultures still survive and in some cases even thrive. Lowland economies have generally dominated, however, because of intensive sedentary agriculture, manufacturing based on larger scales, easier transportation and trade, urbanization and associated better education, and the broader reach of common language and culture.

In most parts of the world, mountain areas are perceived as economically backward and culturally inferior. But there are some exceptions. In industrial countries, mountain areas have been rapidly transformed economically with improved access and the proliferation of recreational activities. In Africa, for instance, highland areas that grow tea and other high-value crops are more prosperous than lowlands. More often, however, mountain resources are extracted without benefit to local communities in order to support lowland economies, thereby contributing to the further marginalization of mountain people. Where extractive industries have been developed, mountain communities have often become dependent on wages for their livelihoods, and asset values and rents are usually allocated elsewhere.

With notable exceptions, particularly in areas where tourism and amenities migration (the movement of people because of a perceived high incidence of attractive or cultural resources) have created pockets of wealth, mountain communities suffer disproportionately from poverty and often lack even basic social services such as education and health care facilities. This, in part, has caused a counter movement in several mountain areas (the Andes and Himalayas) that is strongly linked to control over mountain resources (such as the movement of water in Bolivia).

Mountain communities are also insufficiently recognized as rich reservoirs of traditional knowledge and cultural and spiritual resources.

\subsection{Mountain Ecosystem Services}

For the purposes of this assessment, three main types of mountain ecosystem services are addressed:

- Provisioning services: extractive resources that primarily benefit lowland populations (water for drinking and irrigation, timber, and so on) and ecosystem production (agricultural production for local subsistence and for export; pharmaceuticals and medicinal plants; and non-timber forest products);

- Regulating and supporting services, such as biodiversity, watershed and hazard prevention, climate modulation, migration (transport barriers/routes), soil fertility, soil as storage reservoir for water and carbon, and so on; and

- Cultural services: spiritual role of mountains, biodiversity, recreation, and cultural and ethnological diversity.

Each of these mountain ecosystem services makes specific contributions to lowland and highland economies. Mountains play a key role in the water cycle, with feedback to the regional climate and by modulating the runoff regime. Tropical cloud forests are particularly significant in the latter respect. Mountain vegetation and soils play a significant role in reducing or mitigating risks from natural hazards. Mountain forests, for instance, protect from avalanches and rockfall; their waterholding capacity reduces peak stream flow; they are an important carbon pool; and they provide timber for fuelwood and non-timber products, including game and medicinal plants. Mountains are also used for grazing and subsistence farming. Mountain ecosystems are significant for global biodiversity, as noted earlier, and in addition they have intrinsic spiritual and aesthetic value (Bernbaum 1998; Daniggelis 1997).

Table 24.4 rates ecosystem services per unit of specific type of land area. This definition avoids a rating by the abundance of certain land types.

\subsection{Condition and Trends of Mountain Systems}

\subsubsection{Atmospheric Conditions}

Mountains extract moisture from the atmosphere through the orographic uplift of air masses that pass over mountain ranges. In this sense, mountains act as "water pumps" by pulling moisture from the atmosphere. Mountains also act as "water towers" by 
Table 24.4. Ecosystem Services in Mountains

\begin{tabular}{|c|c|c|c|c|c|c|c|c|c|c|c|c|}
\hline \multirow{2}{*}{$\begin{array}{l}\text { Mountain } \\
\text { Type }\end{array}$} & & \multicolumn{2}{|c|}{$\begin{array}{c}\text { Downslope } \\
\text { Safety }\end{array}$} & \multicolumn{2}{|c|}{ Water } & \multicolumn{2}{|c|}{ Food } & \multicolumn{2}{|c|}{ Fiber } & \multicolumn{2}{|c|}{ Medicinal } & \multirow{2}{*}{$\frac{\text { Cultural }}{\text { (Recreational, etc.) }}$} \\
\hline & & Safety & Dams & Fresh water & Energy & Grazing & Crop & Fuel & Timber & Wild & Cultivars & \\
\hline \multirow[t]{2}{*}{ Alpine } & terrestrial & +++ & +++ & +++ & +++ & ++ & - & $\bullet$ & - & +++ & $\bullet$ & ++ \\
\hline & aquatic & $\bullet$ & + & +++ & +++ & - & - & - & - & - & - & + \\
\hline \multirow[t]{2}{*}{ Montane } & terrestrial & +++ & + & +++ & +++ & +++ & +++ & ++ & ++ & +++ & +++ & ++ \\
\hline & aquatic & $\bullet$ & + & +++ & +++ & $\bullet$ & + & $\bullet$ & $\bullet$ & $\bullet$ & $\bullet$ & ++ \\
\hline \multirow{2}{*}{$\begin{array}{l}\text { Hills and } \\
\text { plateaus }\end{array}$} & terrestrial & + & + & + & + & +++ & 0 & ++ & ++ & + & + & +++ \\
\hline & aquatic & $\bullet$ & $\bullet$ & + & + & $\bullet$ & ++ & $\bullet$ & $\bullet$ & $\bullet$ & $\bullet$ & + \\
\hline
\end{tabular}

Key: • not relevant; + relevant; ++ important; +++ very important

storing water in mountain glaciers, permafrost, snowpacks, soil, or groundwater.

There are conflicting predictions about the rate of tropospheric warming. General circulation models predict a warming in high northern latitudes and also in the mid to upper troposphere in the tropics and sub-tropics. Many tropical and subtropical mountain ranges reach the levels of the troposphere where the warming is predicted, and the retreat of many of the world's glaciers is consistent with warming at higher elevations. However, reliable assessments of the status of mountain atmospheric conditions are currently limited to relatively few highelevation meteorological stations. For example, a transect along the Cordilleras of the Americas shows that there are currently no meteorological stations positioned at elevations high enough to address the issue of potential warming in the mid-troposphere in the tropics and sub-tropics.

\subsubsection{Trends in Atmospheric Physics (Climate)}

\subsection{Temperature trends}

Temperature changes in 1951-89 between $30^{\circ}$ and $70^{\circ} \mathrm{N}$ show that mean maximum temperatures increased slightly between 500 and 1,500 meters, with minor changes at higher elevations, while mean minimum temperatures rose by about $0.2 \mathrm{~K}$ per decade from 500 meters to above 2,500 meters (Diaz and Bradley 1997). In the tropical and sub-tropical Andes, mean annual temperature trends for 268 stations between $1^{\circ} \mathrm{N}$ and $23^{\circ} \mathrm{S}$ during 1939-98 (Vuille and Bradley 2000) showed an overall warming of about $0.1 \mathrm{~K}$ per decade, but the rate has tripled over the last 25 years to $0.33 \mathrm{~K}$ per decade. The warming trend declined with elevation, especially on the Pacific slopes of the Andes, whereas in the central Himalaya the warming trend increased with altitude (Shrestha et al. 1999). In the Swiss Alps, temperatures increased by a total of $1 \mathrm{~K}$ during the twentieth century, and milder winters now occur (Beniston and Rebetez 1996). Temperature effects appear to be stronger at night than during the day.

In many locations for which high-elevation monitoring data are available, the rate at which the atmosphere cools with increasing altitude (lapse rates) has shown an increase because of faster warming at lower altitudes. However, there are exceptions. For example, in the Colorado Front Range of the Rocky Mountains there has been an overall cooling at 3,750 meters but warming between 2,500 and 3,100 meters since 1952 (Pepin 2000). Generally, the increase of air temperature lapse rate on mountains at the mid-latitudes is greater in winter than in summer (Yoshino 2002).

There have also been remarkable trends in permafrost temperatures. In the Swiss Alps, for example, permafrost warmed by about $1 \mathrm{~K}$ between 1880 and 1950, then stabilized, before warming accelerated between 1980 and 1994, followed by rapid cooling in 1994-96, which largely offset the previous warming (Vonder Mühll et al. 1998). Permafrost temperatures in the northern Tien Shan have risen by $0.2-0.3 \mathrm{~K}$ over the last 25 years (Gorbunov et al. 2000).

The position of the snow line has been similarly affected. The snowline in mountainous areas within $10^{\circ}$ of the equator retreated by 100-150 meters between 1970 and 1986, which has been correlated with a warming of the sea surface over the eastern tropical Pacific (Diaz and Graham 1996). On the Quelccaya Ice Cap in Peru $\left(14^{\circ} \mathrm{S}\right)$, meltwater penetration obliterated the uppermost part of an important climatic record provided by the ice core that Thompson et al. (1993) had collected only a few years earlier. Thus, some paleo records that are vital for our understanding of human-environment interactions are vanishing fast.

\subsection{Precipitation and snowpack trends}

Precipitation in mountain regions is best assessed through hydrological budgets of catchments. This is because precipitation is highly variable and strongly influenced by dominant wind direction (slope/aspect effects) and because precipitation analysis is complicated by seasonality and the occurrence of extreme events whose statistics are difficult. Records for the Alps (Gurtz et al. 2003; Beniston et al. 2003) suggest a future trend toward higher winter and lower summer precipitation and an increase in the altitude at which freezing occurs, with largest relative changes occurring in alpine catchments. Less summer precipitation in combination with higher evapotranspiration rates will lead to a reduction in soil moisture and groundwater recharge.

Trends in snowpack and snow duration reflect the interplay between temperature and precipitation. Snowpack has already diminished in montane altitudes and is likely to continue to do so, while there may even be an increase in snowpack at upper alpine/ nival elevations due to increased solid precipitations (Beniston 2003). On average, glaciers lost 6,000 to 7,000 millimeters of water from 1980 to 2000 (250-300 millimeters per year, based on the glacier area). (See Figure 24.10.) Unfortunately, few meteorological stations are situated at high altitudes that could address the extent to which the observed changes in mass balance represent increasing summer ablation of ice and snow or a decrease in the accumulation of solid precipitation.

\subsubsection{Trends in Atmospheric Chemistry}

\subsection{Atmospheric deposition of nutrients and pollutants}

Atmospheric processes control the deposition of long-distance pollutants in mountain environments (nutrient enrichment of 

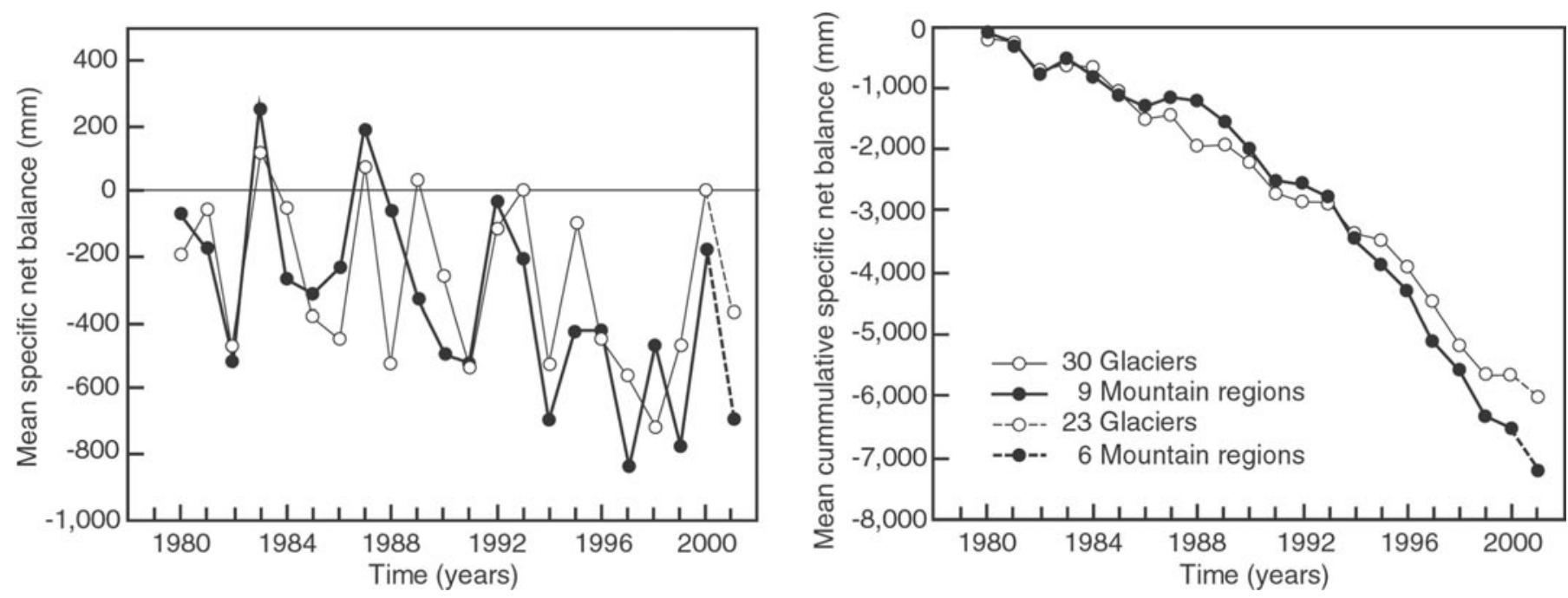

Figure 24.10. Mean Net Balance and Cumulative Mean Net Balance Continuously Measured for 1980-99 on 30 Glaciers in Nine Mountain Ranges. Data for 2000 are for 29 glaciers in eight mountain ranges and preliminary results for 2001 are for 23 glaciers in six mountain ranges. (World Glacier Monitoring Service, at http://www.geo.unizh.ch/wgms/)

mountain ecosystems and impacts on water quality). Atmospheric deposition of nitrogen and sulfur compounds, persistent organic pollutants, and metals such as mercury in mountainous areas is enhanced by proximity to anthropogenic sources and precipitation. For semi-volatile POPs, volatilization in warmer temperatures and condensation in colder temperatures results in increased deposition at high altitudes. For instance, semi-volatile organochlorine compound deposition increased 10- to 100-fold in snowpack with altitude (770-3,100 meters above sea level) in the Canadian Rockies (Blais et al. 1998).

Atmospheric deposition of acids, nutrients, organochlorines, and metals affect all components of mountain ecosystems. The loss of acid-neutralizing capacity in soils caused by the deposition of sulfur and nitrogen compounds reduces soil fertility and biodiversity and acidifies water bodies, leading to alterations in aquatic species composition. Excess nitrogen is undesirable because it induces changes in plant species composition and nutrient cycling, and it affects the ability of plants to withstand stress. Nitrogen enrichment can also increase non-native species invasions in mountainous aquatic or wetland habitats. On the other hand, nitrogen's fertilizing action can be a benefit in areas where enhanced productivity is desired, such as in commercial mountain forests. Rare or endemic species, often found in oligotrophic habitats, are likely to become suppressed by more vigorous species of wider distribution.

A preliminary examination indicates a pattern of biological accumulation of POPs in animals and foliage at high altitudes (Schindler 1999). The occurrence of the insecticide toxaphene in fish increased by 1,000-fold over a 1,500-meter elevation range in the Canadian Rockies, and similar patterns have been observed in the Alps for polychlorinated biphenyl concentrations (Grimalt et al. 2001). Organochlorines and metals are harmful to fish health and reproductive ability, and bioaccumulation transfers poisons to waterfowl, wildlife, and humans.

Atmospheric deposition in conjunction with other disturbances (such as unsuitable land use practices and floods) can create many problems, such as losses of soil nutrients or the accumulation of xenobiotic substances. For example, water from glacial catchments was recently shown to be the dominant sources of POPs in the mountain rivers of Alberta, Canada (Blais et al.
2001). At the same time, however, processes such as $\mathrm{N}$ enrichment may increase species invasions in mountainous aquatic or wetland habitats. Glacial runoff in summer becomes channelized on the glacier surface, funneling POPs rapidly to alpine and subalpine waters. Glacial meltwater also showed evidence of the accumulation of tritium in glacial ice during atmospheric nuclear tests in the 1960s and 1970s (Blais et al. 2001). There is a high probability that under a scenario of increasing global temperatures, glacial melt will lead to unexpectedly high concentrations of POPs in montane waters.

\subsection{Carbon dioxide}

Globally, mountain ecosystems at temperate latitudes are among the largest biotic carbon reserves because these mountains tend to be forested, accounting for, for instance, $25-50 \%$ of the contribution to the total U.S. carbon stock and up to $75 \%$ of the western U.S. carbon stock (Schimel et al. 2002). The effects of elevated $\mathrm{CO}_{2}$ concentration on montane forests vary with nutrient availability and species. Haettenschwiler and Körner (1998) found no effect of elevated $\mathrm{CO}_{2}$ on the growth of montane Picea abies (Norway spruce), and no effect was found in Pinus uncinata (mountain pine) after three years of in situ free air $\mathrm{CO}_{2}$-enrichment (FACE) at the Swiss tree line. However, deciduous larch Larix decidua showed a continuous response, provided trees were not affected by larch bud moth. If this trend in differential growth continues over the long term, it would provide a clear example for $\mathrm{CO}_{2}-$ driven biodiversity effects (Handa et al. in press). Studies of ecosystem productivity in alpine grasslands in the Swiss Alps found no detectable increase after four years of double-ambient $\mathrm{CO}_{2}$ concentration. However, higher $\mathrm{CO}_{2}$ concentrations reduced forage quality, increased (compensatory) herbivory by grasshoppers during certain periods, and altered the plant community composition (Körner et al. 1997).

\subsubsection{Consequences of Atmospheric Changes}

Environmental conditions change rapidly with elevation because of the steep temperature and precipitation gradients. Thus, rapid changes in life zones occur over short vertical distances, and relatively small changes of the climate can induce large changes in the area available for a given life zone (cf. Theurillat and Guisan 
2001). Because topographic effects have a greater influence than elevation effects over conditions for life above the tree line, biota do not necessarily occur at higher altitudes, but may form new mosaics, with the distribution of snow often being far more influential than temperature (Gottfried et al. 1999).

Climatic change may enhance or reduce precipitation, depending on the region. A reduction of moisture in already dry mountain regions (such as the upper Erica belt on Kilimanjaro) will enhance fire frequency. Some mountain forelands will receive less water, with disastrous consequences for marginal semiarid lowlands. Enhanced activities such as El Niño may in turn expose other tropical and sub-tropical regions to excessive precipitation followed by floods and mudslides, as occurred recently in Peru, Ecuador, and Colombia. In many cases, mountains are the primary source of fresh water in these regions.

The reduction in glacier volumes is expected to have a strong impact on dry-season river flows in rivers fed largely by ice melt (Haeberli and Beniston 1998). This will very likely affect the provision of downstream water for drinking, hydropower, and irrigation. Over 65 countries use more than $75 \%$ of their available fresh water for agriculture. These include countries with large populations such as Egypt, India, and China, which rely heavily on mountain discharge (Viviroli et al. 2003). Unfortunately, mitigation efforts such as constructing dams and reservoirs are problematic in tectonically active regions where slope stability is further compromised by glacier recession and melting permafrost (Haeberli and Beniston 1998). Conversely, it is likely that some maritime mountain regions may experience increased precipitation under warmer conditions, which may lead to slope instability, mass movement, and accelerated erosion.

In the Himalayas of Nepal and Bhutan, glacier lake outburst floods are increasing in frequency due to the rapid recession of glaciers. It is anticipated that such events could reach rates of one significant glacier outburst flood each year by 2010 (Kaeaeb et al. 2005), which will impose a substantial risk to downstream communities and hydroelectric power schemes.

Winter tourism is particularly vulnerable to climatic change in areas near the lower winter snowline. For example, it is likely that a number of winter resorts in the European Alps situated below 1,500 meters above sea level will be forced to close in the near future, which in turn will increase demand on high-elevation resorts.

\subsubsection{Mountain Biota}

\subsubsection{Overview of Land Cover in Mountains}

Table 24.5 provides a summary of land cover in mountain areas, obtained by overlaying the global land cover data set for 2000 (Bartholome and Belward 2004) with the modified mountain map of Kapos et al. (2000). Based on this data set, $13.3 \%$ of the mountain area is cultivated, while the urban ("artificial") land area amounts to $0.05 \%$, or 15,400 square kilometer, making it nearly negligible at the global scale.

Overall, it is very likely that about half of the global mountain area is under some sort of human land use (we assume that unvegetated or bare land and wetlands and other water bodies, which together amount to $14 \%$ of the global mountain area, are mostly unaffected by humans). A considerable proportion of forests, including plantation forests, woodlands, and shrubland as well as herbaceous vegetation in mountains are under various human land uses, such as silvicultural interventions and grazing. Probably half of all temperate/boreal forests and two thirds of all tropical mountain forests are under some sort of management (from selective logging and shifting cultivation to plantation forest).
Wildlife - and free-roaming domestic animals — can have a dramatic impact on land cover. For instance, much of the initial fragmentation of montane forest on Mt. Kenya was a consequence of free elephant access. By contrast, deep canyons prevent elephant access to much of the montane cloud forest on Kilimanjaro, which has remained largely intact. Through wildlife management, including hunting and the extensive use of fire, wildlife influences have been modified and have often become less important than those of domestic animals.

\subsubsection{Mountain Forests}

Mountain forests account for $26.5 \%$ or $9.5 \times 10^{6}$ square kilometer (using the 300 meters low elevation threshold in the tropics) of the global closed forest area (Kapos et al. 2000). (See Table 24.6.) The upper forest limit lies at around 4,000 meters in the tropics; it gradually decreases toward the poles and ends near sea level at the polar forest limit. On a large scale, both the mountain and polar tree lines are set by temperature during the growing season (Ohsawa 1990; Körner and Paulsen 2004).

In the Southern Hemisphere, current forests often do not reach the potential climatic limit for tree growth that is predicted for the Northern Hemisphere. (In the Southern Hemisphere, introduced northern temperate trees can grow even above the indigenous species (Nothofagus)'s upper limit (cf. Wardle 1971).) So native species do not always reach their life-form limit. Since there is no land in the extreme south, deciduous and coniferous boreal forests are absent in the Southern Hemisphere, and evergreen temperate trees form the southern forest limit.

A continuous zonation of humid forests from the equator to the poleward forest limit can be observed in the mountain chains from humid, monsoon Southeast Asia to East Asia, and from the Northern to Southern Andes. In the other parts of the world, the forest area is interrupted by drylands between the equatorial and the temperate mountains.

The number of distinct elevational belts within the montane forest belt decreases toward higher latitudes (Holdrige 1967; Brown et al. 1991). Humid tropical montane forests are dominated by evergreen broad-leaved trees, from the foothills to the upper forest limit. (See Figure 24.11.) In temperate mountains, a marked altitudinal sequence of evergreen, deciduous, and coniferous forests can be found, but this varies from continent to continent. In North America and Europe, the evergreen broad leaf component is missing, while New Zealand has no conifer or deciduous belt. The presence or absence of conifers and deciduous trees in tropical versus temperate mountains suggests large differences in ecosystem functioning (seasonality, water, and nutrient relations).

\subsection{Natural, unmanaged forests}

Natural, unmanaged mountain forests are becoming rare. They are often isolated or fragmented but host a rich and original flora and fauna. What is commonly termed "natural" may still include some human activities, but these do not normally alter the abundance and composition of forest species. Many of these forests are relicts with varied protection status. Nearly $10 \%$ of the global mountain forests are under some sort of protection (UNEPWCMC 2002). Recent networks of protected areas in many parts of the world aim at establishing connections using ecological corridor systems (for example, Bhutan). These forests are essential to protect fragile mountain slopes from erosion and leaching processes and as reservoirs of species for resettlement of deforested, fragmented, or newly created habitats affected by anthropogenic or natural disturbances. 
Table 24.5. Land Cover in Mountains. The share of different land use types in each biogeographical zone is provided in parentheses.

(Bartholome and Belward 2004, UNEP-WCMC updated by Thonell using the formation categorization by Ohsawa (1995 modified)) The criteria for the humid life zones are as follows (WI is defined as the sum of monthly mean temperature above $5^{\circ}$ Celsius (Kira 1948), CMT is defined as the coldest monthly mean temperature (Ohsawa, unpublished)):

- Tropical life zone (latitude below $\left.20-30^{\circ} \mathrm{N} / \mathrm{S}\right)$ : WI $<15\left(\mathrm{CMT}>-1^{\circ} \mathrm{C}\right)=$ above limit of tropical forest; $15<\mathrm{Wl}<85\left(\mathrm{CMT}>6^{\circ} \mathrm{C}\right)=$ tropical upper montane zone; $85<\mathrm{WI}<240\left(\mathrm{CMT}>12^{\circ} \mathrm{C}\right)=$ tropical lower montane zone; WI $>240\left(\mathrm{CMT}>18^{\circ} \mathrm{C}\right)=$ tropical hill zone if elevation is above $300 \mathrm{~m}$, otherwise not mountainous.

- Sub-tropical/temperate life zone (latitude above ca. $30^{\circ} \mathrm{N} / \mathrm{S}$ ): $\mathrm{WI}<15=$ above limit of temperate forest; $\mathrm{CMT}<-7^{\circ} \mathrm{C}=$ temperate upper montane zone; $-1^{\circ} \mathrm{C}>\mathrm{CMT}>-7^{\circ} \mathrm{C}(\mathrm{WI}>15)=$ temperate lower montane zone; $6^{\circ} \mathrm{C}>\mathrm{CMT}>-1^{\circ} \mathrm{C}, 12^{\circ} \mathrm{C}>\mathrm{CMT}>-1^{\circ} \mathrm{C}$ and $\mathrm{WI}>85=$ temperate hill zone.

- For dry life zones, the Holdridge life zone classes (scrub, steppe, woodlands, dry tundra, and desert vegetation) have been used.

(Holdridge 1967)

\begin{tabular}{|c|c|c|c|c|c|c|c|c|c|}
\hline $\begin{array}{l}\text { Biogeographical } \\
\text { Zone }\end{array}$ & $\begin{array}{l}\text { Forest and } \\
\text { Woodland } \\
\text { Cover }\end{array}$ & $\begin{array}{l}\text { Shrub, } \\
\text { Herbaceous } \\
\text { Cover }\end{array}$ & Cultivated & $\begin{array}{l}\text { Wetlands } \\
\text { (mires, } \\
\text { swamps, } \\
\text { river } \\
\text { basins) }\end{array}$ & $\begin{array}{c}\text { Bare Areas } \\
\text { (rock, gravel, } \\
\text { etc.) }\end{array}$ & $\begin{array}{l}\text { Water Bodies } \\
\text { (including } \\
\text { snow and ice) }\end{array}$ & $\begin{array}{l}\text { Artificial } \\
\text { (urban, } \\
\text { industrial, } \\
\text { etc.) }\end{array}$ & $\begin{array}{l}\text { No } \\
\text { Data }\end{array}$ & Total \\
\hline & \multicolumn{9}{|c|}{ (square kilometers and percent of total area) } \\
\hline Humid tropical hill & $525,415(56)$ & $155,115(15)$ & $255,130(27)$ & $1,392(0)$ & $2,052(0)$ & $3,125(0)$ & $188(0)$ & $118(0)$ & 942,535 \\
\hline $\begin{array}{l}\text { Humid tropical upper } \\
\text { montane }\end{array}$ & $73,604(34)$ & $97,726(46)$ & $37,814(18)$ & $367(0)$ & $2,999(1)$ & $1,319(1)$ & $71(0)$ & - & 213,900 \\
\hline $\begin{array}{l}\text { Humid temperate hill and } \\
\text { lower montane }\end{array}$ & $2,001,526(51)$ & $1,120,418(29)$ & $638,096(17)$ & $4,428(0)$ & $68,035(2)$ & $36,152(1)$ & $4,701(0)$ & $114(0)$ & $3,918,620$ \\
\hline $\begin{array}{l}\text { Humid temperate lower/ } \\
\text { mid-montane }\end{array}$ & $964,836(60)$ & $342,793(21)$ & $227,184(14)$ & $12,998(1)$ & $13,687(1)$ & $41,466(3)$ & $2,480(0)$ & - & $1,605,558$ \\
\hline $\begin{array}{l}\text { Humid temperate } \\
\text { upper montane }\end{array}$ & $3,448,322(67)$ & $1,080,996(21)$ & $267,071(5)$ & $70,520(1)$ & $178,840(3)$ & $135,509(3)$ & $642(0)$ & $167(0)$ & $5,181,900$ \\
\hline Dry tropical hill & $42,093(9)$ & $170,368(36)$ & $88,317(19)$ & $559(0)$ & $164,465(35)$ & $1,927(0)$ & $170(0)$ & - & 467,899 \\
\hline Dry sub-tropical hill & $141,055(7)$ & $789,890(38)$ & $113,898(5)$ & $1,409(0)$ & $1,035,832(5)$ & $2,508(0)$ & $1,138(0)$ & - & $2,085,730$ \\
\hline $\begin{array}{l}\text { Dry warm temperate } \\
\text { lower montane }\end{array}$ & $146,996(11)$ & $743,592(54)$ & $117,200(9)$ & $380(0)$ & $353,788(26)$ & $5,521(0)$ & $650(0)$ & - & $1,368,127$ \\
\hline $\begin{array}{l}\text { Dry cool temperate } \\
\text { montane }\end{array}$ & $526,173(18)$ & $1,547,610(53)$ & $430,737(15)$ & $3,658(0)$ & $419,257(14)$ & $16,593(1)$ & $3,227(0)$ & - & $2,947,255$ \\
\hline Dry boreal/sub-alpine & $250,670(25)$ & 420,964 (42) & $92,869(9)$ & $4,821(0)$ & $207,577(21)$ & $34,253(3)$ & $279(0)$ & - & $1,011,533$ \\
\hline Dry subpolar/alpine & $115,462(36)$ & $121,795(38)$ & $938(0)$ & $1,634(1)$ & $59,846(19)$ & $22,798(7)$ & $114(0)$ & - & 322,587 \\
\hline Polar/nival & $458,843(8)$ & $2,952,626) 56)$ & $69,345(1)$ & $20,717(0)$ & $771,042(14)$ & $1,305,532(23)$ & $52(0)$ & - & $5,578,157$ \\
\hline Total area & $12,132,775(37)$ & $11,814,671(36)$ & $3,825,843(12)$ & $162,028(0)$ & $3,408,690(10)$ & $1,799,839(5)$ & $16,303(0)$ & - & $33,165,196$ \\
\hline
\end{tabular}

\subsection{Semi-natural forests}

Human use has turned most natural forests into semi-natural forests, a process often completed several centuries ago in Europe but still going on in other mountain areas of the world. Thus semi-natural forests have become part of ecosystems in many parts of the world and are essential for local people to obtain both timber and non-timber forest products.

Large-scale forest statistics (e.g., FAO 2001) do not differentiate between high and low human impacts on forests, however. Sustainably managed semi-natural forests provide many ecosystem services, including tradable products such as timber and various non-timber products, and at the same time retain high biodiversity (Peterken 1981). But heavily disturbed or damaged montane forests are often invaded by fast-growing, early successional tree or shrub species. These pioneers often endanger relic species of the Tertiary (e.g., the Dove tree Tetracentron in western China, cf.
Tang and Ohsawa 2002). On the other hand, such species may be crucial for the conservation of disturbed mountain ecosystems through their role of covering and stabilizing steep slopes and facilitating forest regeneration (cf. Bormann and Likens 1979).

The invasion of unpalatable herbs into overgrazed pastures and of small trees/shrubs into clearings is often regarded as noxious, but, again, these species may reduce nutrient loss, enhance the resilience of the ecosystem, and facilitate restoration (Callaway et al. 2000). In some cases alien species even invade pristine forests once established in disturbed areas (e.g., exotic Myrica faya invades undisturbed Metrosideros forests in Hawaii). Shifting agriculture systems in areas of low population density can maintain ecosystem integrity similar to coppiced forest systems, provided the replenishment of soil nutrients is achieved by allowing sufficient fallow periods. Exploitative farming systems with too short a fallow period (as is the case in systems where human population density is increasing) are not sustainable. 
Table 24.6. Areas of Different Forest Types Occurring in Each Mountain Class (UNEP-WCMC 2003; FAO 2003)

\begin{tabular}{|c|c|c|c|c|c|c|c|}
\hline Elevation Class & $\begin{array}{l}\text { Temperate and } \\
\text { Boreal Evergreen } \\
\text { Needleleaf } \\
\text { Forests }\end{array}$ & $\begin{array}{l}\text { Temperate and } \\
\text { Boreal Deciduous } \\
\text { Needleleaf } \\
\text { Forests }\end{array}$ & $\begin{array}{l}\text { Temperate and } \\
\text { Boreal Deciduous } \\
\text { Broadleaf and } \\
\text { Mixed Forests }\end{array}$ & $\begin{array}{l}\text { Tropical (and } \\
\text { Sub-tropical) } \\
\text { Dry Forests }\end{array}$ & $\begin{array}{l}\text { Tropical (and } \\
\text { Sub-tropical) } \\
\text { Moist Forests }\end{array}$ & Total & $\begin{array}{c}\text { Forest Area/ } \\
\text { Mountain } \\
\text { Area }\end{array}$ \\
\hline & \multicolumn{6}{|c|}{ (thousand square kilometers) } & (percent) \\
\hline Above 3,500 meters & 25.0 & & 1.7 & 0.2 & 19.4 & 23.3 & 1.3 \\
\hline $2,500-3,500$ meters & 151.8 & 1.2 & 122.9 & 35.3 & 138.8 & 450.8 & 6.5 \\
\hline $1,500-2,500$ meters & 548.0 & 76.2 & 476.9 & 50.6 & 277.0 & $1,551.3$ & 29.4 \\
\hline $1,000-1,500$ meters & 788.7 & 313.9 & 441.1 & 107.3 & 545.7 & $2,133.0$ & 34.6 \\
\hline $300-1,000$ meters & $1,377.1$ & 985.6 & $1,275.7$ & 343.4 & $1,173.0$ & $5,179.4$ & 39.9 \\
\hline Total & $2,890.5$ & $1,377.0$ & $\begin{array}{c}2,338.0 \\
\text { (percent) }\end{array}$ & 551.8 & $2,333.0$ & $9,479.2$ & 26.5 \\
\hline $\begin{array}{l}\text { Share of total mountain } \\
\text { forests }\end{array}$ & 30.4 & 14.5 & 24.7 & 5.8 & 24.6 & 100.0 & \\
\hline Location & $\begin{array}{l}\text { North America, } \\
\text { Europe, Central } \\
\text { Asia, Himalaya }\end{array}$ & $\begin{array}{l}\text { Central Asia, } \\
\text { Northeast Asia }\end{array}$ & $\begin{array}{c}\text { North America, } \\
\text { Southern Andes, } \\
\text { Europe, Himalaya, } \\
\text { Eastern Asia }\end{array}$ & $\begin{array}{l}\text { South Africa, } \\
\text { India }\end{array}$ & $\begin{array}{l}\text { Trop. Andes, } \\
\text { Central } \\
\text { America, } \\
\text { East Africa, } \\
\text { Madagascar, } \\
\text { Southeast Asia }\end{array}$ & & \\
\hline
\end{tabular}

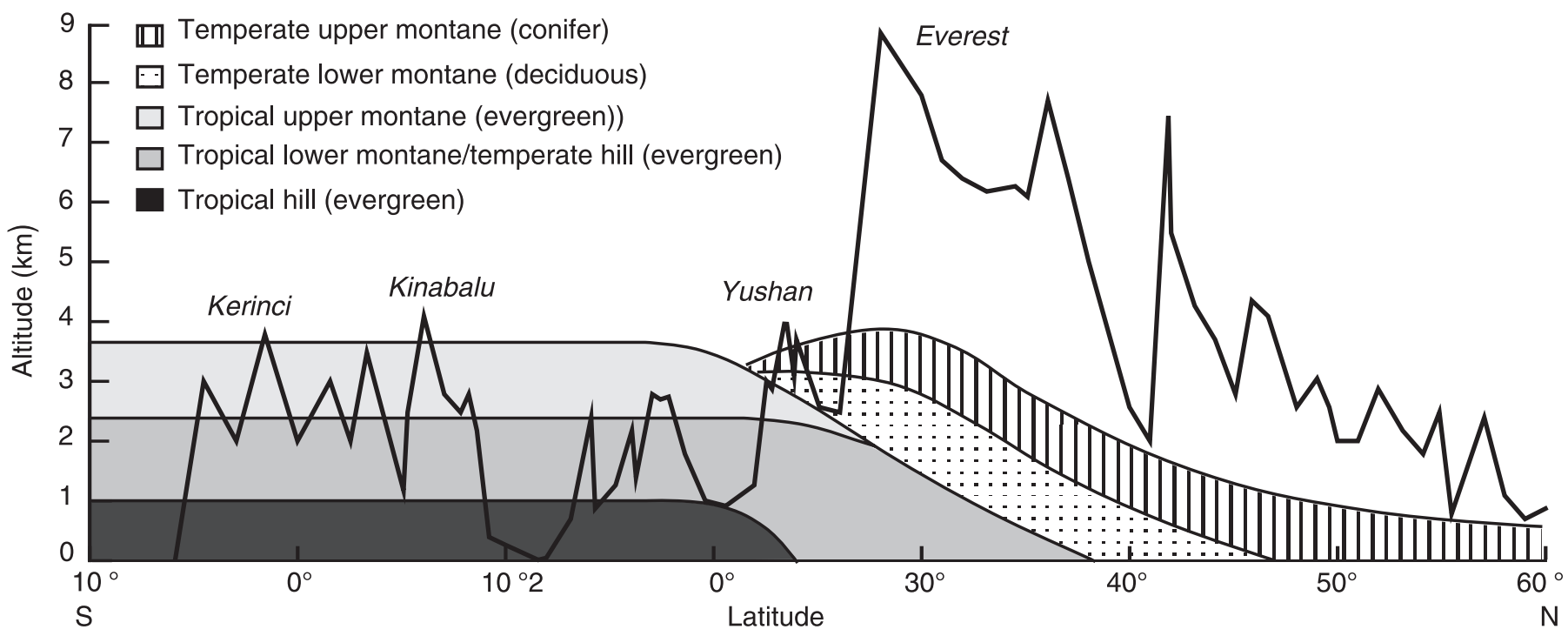

Figure 24.11. Potential Forest Life Zone Model Overlaid on Mountain Profile of Southeast to East Asia. (Ohsawa 1990, 1995) Note maximum of five sub-belts at $23^{\circ} \mathrm{N}$ and the latitudinal reduction of sub-belts to one at $>47^{\circ} \mathrm{N}$.

\subsection{Plantations}

Forest plantations occur mainly in temperate countries $(75 \%$ of the global area of plantation forest); the rest are found in tropical countries. In sub-tropical and tropical humid mountains, the slow-growing natural hardwood forests are often replaced by fastgrowing softwood species, and such plantations extract more water and reduce catchment yields, such as in South Africa, New Zealand, and some parts of the Andes (Hofstede et al. 2002; Morris 1997). In some cases, exotic plantations or ornamental trees introduce diseases and pests.

Large-scale monospecific plantations may exclude wild or domesticated herbivores and lead to a shift in their habitat selection toward the remaining natural or semi-natural forest fragments, thus causing excessive animal densities and deterioration in these more natural forests. When introduced species invade natural forests, they may suppress the regeneration of native species that protect soils from erosion and are important for biodiversity conservation. Recent trends in industrial countries suggest that productive exotic tree plantations can be converted back into less productive but lower risk systems dominated by native trees (FAO 2003). However, plantations can also have an important role in the process of restoring degraded land, as in Ethiopia (Yirdaw 2001), and act as catalysts for succession of native tree species at low population densities.

Recent changes in how forest services are valued, with a shift from simple timber production toward biodiversity, aesthetic, 
spiritual, and recreational aspects, may help change forest plantations to more natural forest in some cases.

\subsection{Trends in mountain forests}

Considerable changes are taking place in mountain forests as a result of overgrazing, pathogens, fire, and direct transformation of forest into other uses, such as plantations and agriculture. Development projects, such as dams, hydropower plants, roads, tourist infrastructure, and urbanization, also contribute to forest loss. In their global forest statistics, FAO (2003) distinguishes three types of new forest area: reforestation, afforestation, and natural expansion of forest. A comprehensive analysis of the change in forest area for the period 1990-2000 showed that natural forest area decreased by $6.8 \%$ in the tropics, while in temperate areas it expanded by $1.2 \%$, mainly due to increases in forest cover in the mountainous countries of Europe (FAO 2001). (See also Chapter 21.)

\subsubsection{Agricultural Systems}

According to a recent FAO estimate, 78\% of the world's mountain area is unsuitable or only marginally suitable for growing crops (Huddleston et al. 2003). Pastoralism and forestry are the predominant uses of mountain land in all regions. Nevertheless, agriculture remains important for a large number of people who will continue to depend on it as their main source of livelihood for the foreseeable future (see later sections on traditional use and vulnerability). Mountain livelihood systems are generally diverse within a variety of agricultural and nonagricultural activities. Typical mountain dwellers grow a wide range of crops and often multiple varieties of each crop. Small-scale livestock production, timber, hunting, fishing, and non-timber forest product collection complement food production. Nonagricultural activities frequently include seasonal migration of men to other areas and tourism, such as mountain guiding and nature conservation work.

In developing and transition countries, $7 \%$ of the total mountain area is currently classified as cropland; forest and grazing land cover about $25 \%$ each, and the rest is barren (33\%) or within protected areas (10\%) (Huddleston et al. 2003).

Above 2,500 meters, $88 \%$ of the total mountain area represents a mix of grazing land and sparsely vegetated or barren land. Sparsely vegetated high lands support about 5 million people; 29 million live off grazing land, interspersed with other land cover types; and 4 million live in protected areas. Forests above 2,500 meters provide home for another 2 million people. Mixed land use patterns - such as crop agriculture combined with exploitation of forest resources and herding of small livestock-are characteristic of some locations between 2,500 and 3,500 meters (mountain class 3) in Central and South America, in the East African and Ethiopian Highlands, and in Nepal. Although mountain people in these locations are increasingly vulnerable, their numbers are quite small. Two million people live in rural areas above 2,500 meters, which are mainly classified as cropland or mixed use. Cropland at higher elevations constitutes only $3 \%$ of the total mountain area.

Below 2,500 meters, grazing land interspersed with other land cover types accounts for $45 \%$ of the land, with a further $20 \%$ classified as mainly barren land. Around 300 million people, or two thirds of the rural mountain population below 2,500 meters, inhabit these areas and rely on livestock for income with some crop agriculture (Huddleston et al. 2003).

These findings confirm the importance of pastoralism for mountain people at all elevations. However, the loss of traditional trade routes and patterns of goods exchange, degradation of land resulting from population growth and increase in livestock numbers, and the impact of frequent, severe droughts in recent years have all greatly increased the vulnerability of this livelihood system, with mountaineering, tourism, or seasonal migration offering the only major alternatives for income generation. In the absence of men, women are forced back into crop agriculture, which is barely suited to the land.

FAO has identified 17 distinct farming systems that are significant in mountain areas at elevations above 1,000 meters. (See Table 24.7.) Together, these systems account for $67 \%$ of the total mountain area and include $82 \%$ of the total rural mountain population in developing and transition countries. The "intensive mixed highland farming system," a livestock-dependent system, is by far the most important. Stretching from northern Africa to Southeast Asia and beyond, this system has many variants that are specific to local cultures and conditions. In the Ethiopian Highlands (1,800-3,000 meters), Near East and North Africa (3002,000 meters), Hindu Kush-Himalaya (1,500-2,500 meters), and central Andes (1,500-3,000 meters), the main features of the system usually include cereals, legumes, potatoes, fodder trees and crops, ruminant livestock, coffee, and horticultural tree crops, with the sale of wool, meat, and tree fruits constituting the main sources of income. By contrast, in western China (500-1,500 meters) rice is important, and income is derived mainly from the sale of vegetables, fruits, pigs, and poultry.

\subsection{Mountain crops}

The major mountain crops grown at high elevation are potatoes and cereals (such as barley), in some tropical and sub-tropical regions grown up to 4,000 meters (and locally even higher). One cash crop of the high Andes is quinoa. At lower elevations, maize (corn), rice, beans, peas, and sweet potato as well as cabbage are important as staple foods globally. At the lowest tropical montane elevations, crops such as taro (Xanthosoma, Colocasia), yams (Dioscorea), cassava (Manihot), bananas, and papayas are grown. Various forms of millet and sorghum play a key role in African mountain agriculture.

Major plantation crops grown in the lower montane belt are tea and coffee: the latter at higher altitudes in Colombia and in montane regions of Brazil, Costa Rica, Guatemala, Viet Nam, and elsewhere, while tea is grown extensively in hill areas and the highlands of Africa and Asia. The presence of traditional crops, which can also be used to produce illegal crops (marijuana, coca, poppy) are a major socioeconomic and political problem in parts of the Andes, Atlas, Afghanistan, and Central and Southeast Asia. In some parts of the high Andes, industrial potato production is threatening the Parámo flora, which is rich in species and endemism.

\subsection{Mountain rangeland}

Mountain rangelands may be natural (vegetation above the tree line) or of anthropogenic origin (below the tree line). In the Alps, for example, a 60-kilometer North-South transect across the main divide revealed that $57 \%$ of the land is covered by meadows, pastures, and other types of palatable low-stature vegetation (Körner 1989). The vegetation of these rangelands is composed of species formerly found along rivers, in naturally disturbed areas and pockets grazed by wild herbivores. These species underwent selective pressure from human land use and assembled into highly adapted plant communities, which over millennia have formed closed and extensive ground cover on nonforested land. 
Table 24.7. Main Mountain Farming Systems in Developing and Transition Countries: Location, Characteristics, Area, and Rural Population. Population numbers refer to number of people living in these areas. (Huddleston et al. 2003; definition of farming systems, Dixon et al. 2001)

\begin{tabular}{|c|c|c|c|c|}
\hline $\begin{array}{l}\text { Mountain Farming } \\
\text { System Categories }\end{array}$ & Farming Systems & Area & $\begin{array}{c}\text { Rural } \\
\text { Population }\end{array}$ & Elevation and Geographical Location \\
\hline & & (mill. sq. km.) & (million) & \\
\hline Other & not specified & 7.4 & 88.2 & Below 1,000 meters-all regions \\
\hline Irrigated & irrigated rice & 1.0 & 38.6 & $\begin{array}{l}\text { 300-2,500 meters-Madagascar and some mountain riverbanks in } \\
\text { Africa; coastal areas of Chile, Ecuador, and Peru and of Caspian and } \\
\text { Aral Seas; terraced hills of Mexico, and South and Southeast Asia }\end{array}$ \\
\hline $\begin{array}{l}\text { Tree crop/sparse } \\
\text { forest }\end{array}$ & $\begin{array}{l}\text { maize mixed } \\
\text { maize-bean }\end{array}$ & 3.5 & 37.3 & $\begin{array}{l}300-1,500 \text { meters_-hilly areas of West African coastal countries from } \\
\text { Côte d'Ivoire to Angola; 500-3,000 meters—-highlands of Burundi, } \\
\text { Ethiopia, Rwanda, and Uganda; Indonesia, Malaysia, Mongolia, } \\
\text { Myanmar, Pacific Islands, northern Argentina and southern Chile, } \\
\text { western Chile }\end{array}$ \\
\hline $\begin{array}{l}\text { Small-scale } \\
\text { cereal-livestock }\end{array}$ & small-scale cereal livestock & 3.5 & 224.3 & $300-2,500$ meters-Turkey \\
\hline $\begin{array}{l}\text { Highland intensive } \\
\text { mixed }\end{array}$ & $\begin{array}{l}\text { highland temperate mixed } \\
\text { highland mixed } \\
\text { upland intensive mixed } \\
\text { intensive highland mixed }\end{array}$ & 2.0 & 50.7 & $\begin{array}{l}\text { 300-3,000 meters-Ethiopian Highlands and small pockets in Angola, } \\
\text { Cameroon, Eritrea, Lesotho, and Nigeria; Himalayan, South Asian, } \\
\text { Near Eastern and North African hills; Indonesia, northern Thailand, } \\
\text { Philippines, South China, and Viet Nam; Colombia, Ecuador, and } \\
\text { Venezuela }\end{array}$ \\
\hline $\begin{array}{l}\text { Highland extensive } \\
\text { mixed }\end{array}$ & $\begin{array}{l}\text { upland extensive mixed } \\
\text { high altitude mixed }\end{array}$ & 2.3 & 11.1 & $\begin{array}{l}\text { 800-4,500 meters and above-Cambodia, Indonesia, Laos, Myanmar, } \\
\text { northern Thailand, Philippines, southeastern China, Viet Nam; Bolivia, } \\
\text { northern Chile, northwestern Argentina, and Peru }\end{array}$ \\
\hline
\end{tabular}

Total

Present in the upper montane and alpine belt across the globe, these ecosystems reflect traditional, sustainable land use and represent biota of high ecological, conservation, and economic value. In many places they host unique and species rich assemblages of plants and wildlife and can often support 50 species or more of higher plants in a 100-square-meter area. The best examples of such rangeland assemblages are found in Europe, including the Caucasus, and across the Himalayas into western China. These high-altitude rangeland systems and their sustained productivity depend on appropriate land use (see vulnerability section later) and represent a cultural heritage that deserves protection. As with forests, increasingly intensive use is occurring over ever increasing areas in many parts of the world, causing loss of sustainability, land transformation with associated changes in ecosystem function, and, in extreme cases, a loss of ecosystem integrity and soils.

The general trends reflect the common economic, developmental, and demographic differences between industrial and developing countries. While abandonment of high-elevation rangelands is common in the former (in France, for instance), overexploitation has reached dramatic dimensions in many developing coun- tries (Ethiopia and Nepal, to name two), a result of unprecedented population pressure. The long-term consequences will very likely be similar to those seen today in part of the Mediterranean coastal mountains, where overutilization has often been followed by catastrophic erosion, complete loss of soils, and conversion of flora and fauna (van der Knaap and van Leeuwen 1995).

The key to sustainable management of high-elevation rangeland has proved to be strict control of grazing. Prevention of loss of soil (productivity) has high potential as a policy-making intervention. In the Kosciusko National Park and Biosphere Reserve in the Snowy Mountains of Australia, for example, phasing out inappropriate grazing helped protect vegetation in an upland catchment, increasing the value for hydroelectric generation. In the absence of urgent measures, it is very likely that developing countries risk large-scale environmental degradation from overgrazing of mountain rangeland, with stark consequences for a large fraction of their current and future populations.

Through the abandonment of traditional grazing lands, industrial countries also risk a decrease in the landscape value of their mountains and the loss of a resource for quality food production. 
In 30-50 years, abandoned pastures revert back, through scrub, to montane forest as long as seed sources are present. It is nearly impossible to reverse this process, because of both high costs and the loss of traditional knowledge. Abandonment of grazing management in mountain ecosystems that have a long history of grazing can also have adverse effects on the survival of some native plant species, many of which may be endemic. Traditional use is affordable only if all benefits are accounted for.

A remarkable secondary benefit of maintaining good quality grazing land is the benefit to hydro-schemes. The extra value in hydropower often exceeds the monetary value of the agricultural yield. In the Alps, and similarly for the Caucasus, the monetary value of an intact, high-elevation, short grass pasture in terms of hydroelectric yield was estimated to be about 150 Euro per hectare, higher than that of abandoned long grass turf or forest (Körner 1989).

\subsubsection{Alpine Biota}

The area of alpine land above the natural climatic tree line accounts for about 3\% of the planet's land surface. Depending on region, most arctic-alpine vegetation north of $65-70^{\circ}$ is probably better included in the term "arctic." The alpine belt alone supports about 10,000 plant species worldwide (Körner 1995), corresponding to $4 \%$ of the total number of known species of flowering plants. Local flora of individual mountains (except for isolated volcanic peaks) throughout the world consist of 200-300 species, a surprisingly constant number (Körner 1995). The compression of climatic zones, high fragmentation and topographically diverse habitats, geographic isolation, glaciation, and varied history of species migration or evolution have led to high degrees of taxonomic richness (including endemism) in alpine biota (Nagy et al. 2003; Körner 2004).

Treeless by definition, the alpine belt is in large part composed of dwarf shrub heath and grassland, a vegetation that dominates the headwaters of most major river systems. In the tropics and sub-tropics, but also in the oceanic Southern Hemisphere temperate and subpolar zone, tall tussock grasses represent the dominant life form. In most parts of the world the wild ungulate grazers of this life zone have been replaced by domestic species. Animal trampling of fragile soils on steep terrain and fire management of tussock grasses are the major threats to the biota. In fact, the overdominance of tussocks versus more palatable low-stature grass cover has been interpreted as a consequence of excessive land use (Hofstede 1995). Inter-tussock surface erosion is a major problem associated with insufficient or weakened inter-tussock vegetation.

Since soil development is very slow at these elevations, revegetation after the loss of substrate is nearly impossible. In many parts of the world, alpine vegetation extends to below the climatic tree limit because of forest destruction. Together with forest preservation, the sustained integrity of these highland ecosystems is key to the quality and quantity of catchment discharge. Indeed, the ecosystem engineering role of species-rich alpine biota has become a focal area of internationally coordinated research (Körner and Spehn 2002; Spehn et al. 2005).

With respect to ecosystem productivity, neither atmospheric $\mathrm{CO}_{2}$-enriched nor moderate climatic warming appear to exert significant effects on alpine systems. It seems that productivity is not limited by the availability of $\mathrm{CO}_{2}$, and thermal conditions in the low stature ground cover are much more controlled by radiative solar heating than is the case in trees and forests, which are aerodynamically well coupled to atmospheric circulation (Körner 2003). At high latitudes, temporal and spatial patterns of alpine snow pack exert strong influences on vegetation, with patterns of precipitation, particularly during the cold season, being potentially more significant than summer temperatures. In addition to changes in precipitation and snow pack, major global threats in the alpine belt are regional nitrogen deposition and land use. Warming can open higher elevation habitats for organisms from lower altitudes, provided the summits are high enough (Grabherr et al. 1994).

\subsubsection{Aquatic Biota}

Mountain lakes, ponds, and streams provide important ecosystem services - including drinking water, fish, recreation, and aesthetic values. The productivity and diversity of algae, invertebrates, and fish decline significantly with increasing altitude because of the more extreme environmental conditions, such as low temperatures, short season, and low nutrient concentrations, and the isolation (Vinebrooke and Leavitt 1999), causing such biota to be more sensitive to any change in environmental conditions (Donald et al. 2001).Consequently, the migratory responses of mountain aquatic biota are closely tied to changes in the environment (e.g., Donald et al. 2001). Human actions, such as widespread introduction of exotic fish, led to significant biological impoverishment of montane and alpine lakes and streams during the twentieth century, which may require decades to recover from (Donald et al. 2001; Schindler and Parker 2002).

Oligotrophic aquatic ecosystems in mountains rely heavily on external inputs of nutrients (Vinebrooke and Leavitt 1998), which make them highly sensitive to human land use practices and air pollution. For example, nitrogen deposition impacts have been documented from oligotrophic mountain lakes in the western United States (Baron et al. 2000) and from streams in the HinduKush Himalayas (Jenkins 2002). Cold climate aquatic biota also show pronounced accumulation of mercury and organochlorine compounds at higher elevations as a result of low temperature condensation of emissions originating from lower elevations and of release from melting glaciers in both North America (Blais et al. 2001) and Europe (Rognerud et al. 2002). However, the sensitivity of species-poor mountain aquatic ecosystems makes them excellent early indicators of environmental change.

Climate warming and drought have pronounced impacts on biota in non-glacial lakes and streams as they become clearer, warmer, less acidic, and more ephemeral because of reduced snowpack and increased mineralization rates (Sommaruga-Wögrath et al. 1997). Interactions between multiple environmental stressors, such as introduction of exotic species, air pollution, climate warming, and human land use, determine the cumulative impact of global change on aquatic mountain biota (Battarbee et al. 2002).

\subsubsection{Mountain Watersheds}

The relationship between vegetation, soil, and water is best expressed in the functioning of the hydrologic unit - the watershed. Watersheds integrate conditions and processes over large areas and determine the functionality of their ecosystems and the water yield for river systems, which provide essential fresh water for aquatic life (including fisheries), agriculture, hydropower generation, and industrial and domestic use for growing populations both in the mountains and in the lowlands. More than 3 billion people depend directly or indirectly on water from mountains.

\subsubsection{The Hydrological Importance of Mountains}

One of the most important services from mountain ecosystems is the provision of clean water. In 2000, the Second World Water Forum in The Hague declared that major challenges included: 
- protecting the ecosystems that supply water-that is, the mountains, the water towers;

- managing the risks that have an impact on water supply and distribution - that is, the drivers of change; and

- increasing the valuation and improving the governance of water resources and watersheds.

Mountain areas typically produce about twice the discharge that could be expected from the land area they cover (Viviroli et al. 2003). Mountains account for $20-50 \%$ of the total discharge in humid areas, rising to $50-90 \%$ in semiarid and arid areas mountain watersheds (with extremes over 95\% in the Nile, Colorado, Orange, Syr Darya, Amu Darya, and Rio Negro). (See also Box 24.2.) The drier the lowlands, the greater the importance of the linked and more humid mountain areas that supply them (Viviroli et al. 2003; Liniger et al. 1998). (See Figures 24.12 and 24.13.) Moreover, discharge from mountain areas greatly reduces the intra- and inter-annual variation in total discharge.

\subsubsection{Hydrology and Forests}

Natural forests are hydrologically the most effective land cover in mountain watersheds. They can reduce runoff peaks and local flooding, but this influence decreases with the increasing size of the watershed and distance from the headwaters (Hamilton with King 1983). On very shallow soil in mountains, however, runoff peaks may not be reduced. In monsoon climates, with very high amounts and intensity of precipitation, landslips and mass earth failures may occur even with full forest cover, although the incidence of landslips is greater with other types of land cover. Low-stature vegetation, such as lightly grazed grassland and wellconstructed and maintained terraced cropland, is also effective in maintaining a good and balanced runoff regime.

While removal of forests may increase total water yield, such removal and subsequent land use commonly has a host of undesir-

\section{BOX 24.2 \\ Overutilization of Water from Mountain Areas Leading to Desertification}

The Aral Sea Basin is an example of the importance of mountain water resources and ice and snow storage (Spreafico 1997). The basin includes parts of Afghanistan, Kazakhstan, Kyrgyzstan, Tadjikistan, Turkmenistan, and Uzbekistan and has an area of about 690,000 square kilometers with a population of 32 million.

Home to many civilizations since $6,000 \mathrm{BC}$, irrigation agriculture has been practiced for millennia (today, it covers over 8 million hectares). In the high mountains of the Tien Shan and Pamir, the annual precipitation ranges from 600 to over 2,000 millimeters, with $30 \%$ falling as snow and $60 \%$ of the total precipitation falling between December and May. The lowland deserts that cover most of the basin and are characterized by low rainfall (less than 100 millimeters a year) and high evaporation (potential evaporation as much as 1,500 millimeters a year).

In the summer, snow and glacial melt contribute to the flow of the two main rivers-the Amu Darya in the south and the Syr Darya in the north. The total annual runoff of the rivers in the basin is about 120 cubic kilometers, of which approximately 116 cubic kilometers originate in mountain areas (about 77 cubic kilometers contributed by the Amu Darya, and 39 by the Syr Darya). Thus the mountains provide more than $95 \%$ of the basin's fresh water. More than half a century of overutilization and high evaporative losses have resulted in a massive shrinking of the Aral Sea and in large-scale desertification. (See also in Chapter 20.) able consequences that offset the additional water gain, and forest removal is not usually viewed as a sustainable management option. Because of lower evapotranspiration losses, well-maintained grazing lands can yield more total water than forested land. However, sustainable grazing regimes and well-constructed and maintained terraces are rare. Moreover, erosion can become a serious problem with other land uses.

Under most conditions, continued forest cover in watersheds is essential for the maintenance of hydrological integrity, although caution is needed with plantations of exotic fast-growing species, which often use more water than native forests. Many of the world's biggest cities, including New York, Jakarta, Tokyo, Mumbai, Rio de Janeiro, Los Angeles, Barcelona, Nairobi, Melbourne, Bogota, La Paz, and Mexico City rely on protected forests in catchment areas for much of their drinking water (e.g., Velázquez 2003). In fact, 33 of the world's 105 largest cities get their drinking water directly from formally protected areas (Dudley and Stolten 2003).

Montane cloud forests capture fog or cloud water (horizontal precipitation), which can add substantial amounts of water to the hydrologic system, especially for dry climates with dependable clouds intersecting the mountains (Bruijnzeel and Proctor 1995). This process is mimicked in some dry coastal ranges (in Peru and Chile, for example) where trees or artificial nets have been established to capture this otherwise unused and unavailable water from fog.

\subsubsection{Erosion and Sediments}

Leaf litter, understory vegetation, and forest debris protect the soil from splash erosion-reducing surface, rill, and gully erosion. Moreover the shear strength provided to the soil by tree roots protects against slumping and landslips (O'Loughlin and Ziemer 1982). Soil compaction is less under forest than under other kinds of land cover. Grasslands provide an excellent cover too, but poorly controlled grazing can impair watershed quality. The quality of water delivered from a watershed may also be adversely affected by surface erosion from cropland and by the use of fertilizers and pesticides. Sediments from eroded watersheds impair water quality for many uses, affect aquatic life, and reduce reservoirs' capacity for storage, flood control (see Box 24.3), hydropower generation, and low flow augmentation.

Conservative grazing, horticulture, and cropping, using welltested soil conservation techniques such as terracing, can result in low surface erosion rates and reduced sediment production (Whiteman 1988). Agroforestry systems, fruit orchards, and coffee plantations can reduce shallow landslip incidence by increasing root shear strength. The impact of traditional shifting agriculture depends on the length of fallow periods (full forest recovery), the size of the areas cleared, and the pattern in the landscape (Hamilton with King 1983). Vegetated riparian buffer zones are especially important in mountain watersheds as they act as sediment/ nutrient traps, stream bank stabilizers, and a good habitat for many species of wildlife (Hamilton and Bruijnzeel 1997).

\subsubsection{Dams for Hydropower Production and Irrigation}

The number of reservoirs in upper watersheds and river basins, built largely for the benefit of lowland dwellers, is still increasing, although in industrial countries most of the best sites have already been exploited. Dams change the hydrology of rivers, sediment loads, riparian vegetation, patterns of stream bank erosion, migration of fish, and water temperature and have a multitude of socioeconomic impacts, often including the displacement of local inhabitants. Dams may reduce downstream flooding. 


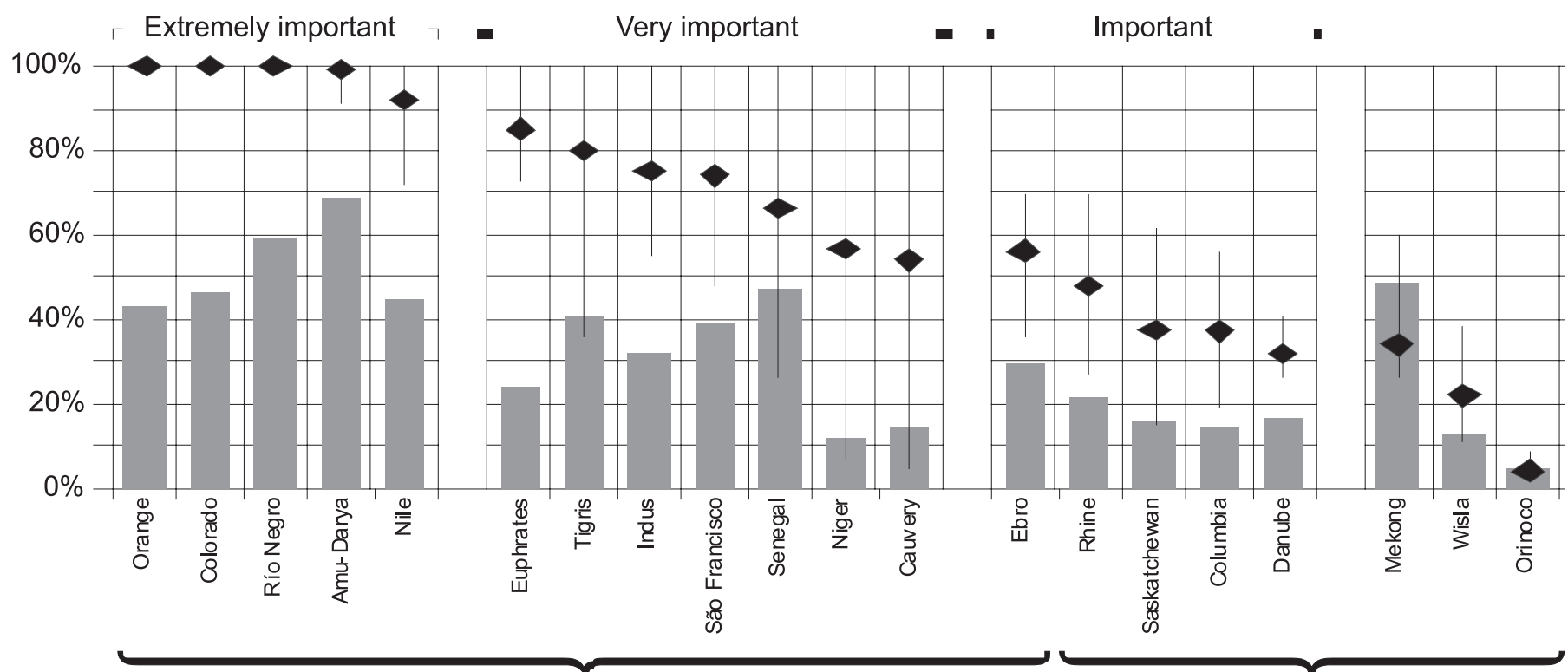

Arid and semiarid areas

Humid areas

Relative size of mountain area

Relative annual contribution of mountain discharge

Figure 24.12. Mean Contribution (Importance) in Percent of Mountain Catchments to the Total Discharge per River System. The vertical lines denote the minimum and maximum contribution. Grey bars illustrate the areal contribution in percent of mountain area to the total area of the river system. Aridity declines from left to right. (Viviroli et al. 2003) Reprinted with the Permission of Mountain Research and Development.

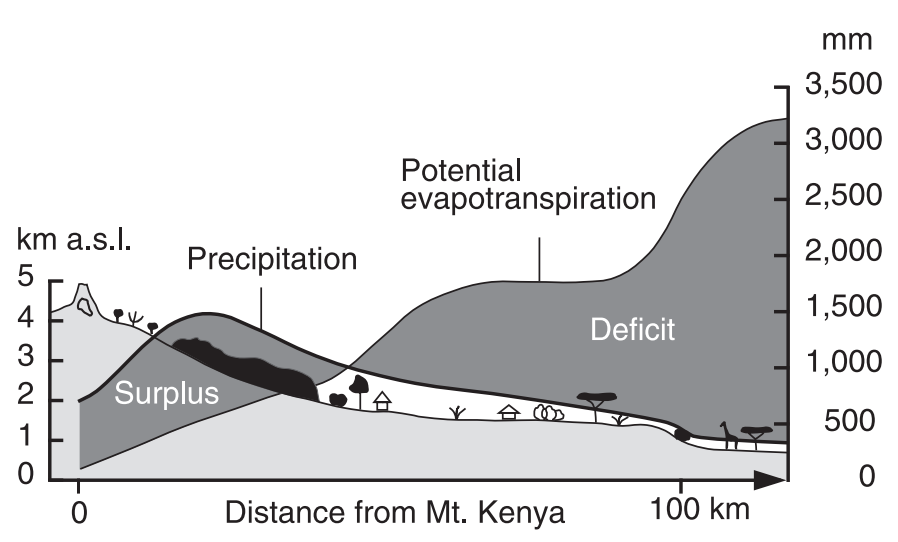

Figure 24.13. Example of the Ewaso Ng'iro River Catchment, Originating from the Slopes of Mount Kenya. Some $90 \%$ of the river flow comes from the upper montane zone (above 2,400 m) of Mount Kenya, supplying the semiarid plateau and the arid lowlands, where water resources are critically scarce during the dry season.

Often, the lifespan of a dam is shorter than calculated, and the cost performance (if one includes all indirect costs) is rather low due to siltation. Policies that provide compensation for environmental services provided by mountain communities (through tariffs on the sale of water or of hydropower, for example) have been shown to have high economic benefits. The water bodies created behind dams can also benefit tourism enterprises or support a reservoir fishery.

\subsubsection{Watershed Management}

Watersheds are fragile environments that depend on a careful balance among many different elements, including soil, water, and
BOX 24.3

Floods, Landslides, and Reservoirs

On 19-20 July 1993, an extraordinary flood, which it was estimated would happen only once in 50-100 years, took place in eastern and central Nepal-with catastrophic effects (DHITAL et al. 1993). Several districts were affected by floods and landslides, a number of dams and roads were damaged, many people died, and many more became homeless. The high sedimentation during the flood halved the life span of the Kulekhani-Reservoir, which is located to the south of Kathmandu in the Bagmati watershed, cutting it from 50 to about 25 years.

both wild and agricultural plant and animal species. Population growth, particularly in cities, is increasing the pressure on watershed areas to provide water and food. As a result, nearly half of the world's population is affected by the degradation of watershed areas, which results from changes in water quantity and quality, sedimentation in lakes and reservoirs, loss of biodiversity, and ecological imbalances. Land abandonment following damming leaves behind complex environmental problems. In the developing world, degraded watersheds are among the most serious constraints to sustainable development.

Emigration has also played a crucial role in determining current watershed condition in developing countries. Demographic changes introduced by migrations strongly affect economic activities and trigger land use change processes that are most severe at upper watershed slopes (Li and Sun 1997).

While recognizing that watershed boundaries do not coincide with political units, there are nonetheless compelling reasons for planning and managing resources with due attention to this hydrologic unit. Easter and Hufschmidt (1985) provided 
this summary of the rational for a watershed approach to rural development:

- The watershed is a functional region defined by physical properties and boundaries.

- The watershed approach allows for evaluation of the biophysical interactions between upland and lowland activities that are linked through the hydrological cycle.

- The watershed approach is holistic and considers multiple facets of resource use and adopts an ecosystem view.

- Land use and natural phenomena in the highlands often result in a chain of environmental reactions downstream that can be readily examined in the watershed context.

- The watershed approach has a strong economic logic. Many of the externalities involved with alternative land management practices on an individual farm are internalized when the watershed is managed as a unit.

- The watershed provides a framework for analyzing interactions between people and the environment. Environmental impacts due to human activity within a watershed feed back to the socioeconomic system.

- The watershed approach can be integrated with programs of forest management, soil conservation, rural and community development, and farming systems.

As catchment limits rarely coincide with political boundaries, transboundary collaboration is normally required for sound catchment management. Effective watershed management requires accounting for interrelationships between highland and lowland areas and needs to involve local populations, as indicated in Agenda 21 (UNCED 1992): "Promoting integrated watershed development programmes through effective participation of local people is a key to preventing further ecological imbalance. An integrated approach is needed for conserving, upgrading and using the natural resource base of land, water, plant, animal and human resources."

\subsubsection{Socioeconomy in Mountains}

\subsubsection{Population}

The global mountain population was estimated in 2000 to be 1.2 billion, or $20 \%$ of the total global population. (See Tables 24.8 and 24.9.) Nearly half (49\%) of these people live in the AsiaPacific region. About $30 \%$ of the mountain population occurs in each of two biogeographical zones-humid tropical lower montane and humid temperate hill and lower montane. Another $12 \%$ live in the dry cool temperate montane zone. (See Table 24.10.) Over $70 \%$ of the global mountain population lives below 1,500 meters, mainly in China. While just $8 \%$ live above 2,500 meters,

Table 24.8. Global Mountain Population Estimate and Share That Is Urban (CIESIN et al. 2004a, 2004b)

\begin{tabular}{lcc} 
Mountain Area Class & Population & Urban \\
\hline & (thousand) & (percent) \\
$\geq 4,500$ meters & 5,405 & 4.6 \\
$3,500-4,500$ meters & 20,541 & 18.8 \\
$2,500-3,500$ meters & 63,373 & 27.7 \\
$1,500-2,500$ meters & 22,700 & 26.8 \\
$1,000-1,500$ meters & 226,292 & 30.3 \\
$300-1,000$ meters & 574,797 & 31.4 \\
Total & $1,113,108$ & 29.7 \\
\hline
\end{tabular}

Table 24.9. Mountain Population by Region and Average Mountain Population Density (CIESIN et al. 2004a)

\begin{tabular}{|c|c|c|c|}
\hline Region & Population & $\begin{array}{c}\text { Share of } \\
\text { Total }\end{array}$ & Density \\
\hline & (thousand) & (percent) & (people/sq. km.) \\
\hline Asia & 597,714 & 49 & 65.2 \\
\hline Former Soviet Union & 34,851 & 3 & 6.4 \\
\hline Latin America & 173,549 & 14 & 37.7 \\
\hline Northern Africa & 141,113 & 12 & 52.3 \\
\hline OECD & 119,559 & 10 & 18.3 \\
\hline Sub-Saharan Africa & 152,613 & 13 & 43.1 \\
\hline World & $1,219,399$ & 100 & 38.2 \\
\hline
\end{tabular}

this still amounts to about 90 million people, almost all considered extremely vulnerable. (See Figures 24.14-24.17 for photographs of mountain dwellers in various parts of the world.)

Most mountain people are rural, particularly in the Asia-Pacific and sub-Saharan Africa regions. Globally, 30\% of mountain people are urban, and settlements in and adjacent to mountain areas are expanding. The urban proportion is particularly high in the humid tropical upper montane, dry cool temperate montane, dry sub-tropical hill, and humid temperate lower-mid montane zones (52\%, 43\%, 39\%, and 37\%, respectively). The populations of the two zones with the greatest numbers of people are more than one quarter urban.

Mountain population density generally decreases with altitude. The total population at 1,500-2,500 meters is only slightly lower than that at 1,000-1,500 meters, however, reflecting more moderate climates and healthier environments above 1,500 meters in tropical mountains. Outside of urban areas, the highest overall density in mountains occurs in the humid temperate hill and lower montane biogoegraphical zone (96 people per square kilometer), which is also the zone with the greatest population. High densities (57-74 people) are also found in other humid zones, both temperate and tropical. The next highest densities occur in the widespread dry cool temperate montane zone (49 people per square kilometer), while the lowest densities (under 9 people) are found in alpine and nival zones.

Population growth rates vary considerably between biogeographical zones, with an average global rate of 16\% from 1990 to 2000. The highest rates are generally in dry biogeographical zones (tropical hill, sub-tropical hill, warm temperate lower montane), which have population densities somewhat lower than the average of 38 people per square kilometer. Of the two zones with the highest populations, the growth rate in the humid tropical lower montane is above the average (22\%), while that in the humid temperate hill and lower montane-the most densely populated-is below it (11\%). Many of the zones with high population growth rates also have infant mortality rates above the global average for mountain populations (58 deaths per 1,000). Rates are also particularly high in the dry boreal subalpine and the humid tropical lower montane (respectively, 85 and 74 deaths per 1,000).

Migration has been characteristic for many mountain peoples since the earliest historical times. The numerous wars affecting mountain regions have led to massive movements of people. While comparison of data between censuses may show gross patterns of change, demographic flows are also often recorded within statistical reporting districts and within annual cycles. Consequently, although the spatial distribution of the population may 
Table 24.10. Global Mountain Population, Share That Is Urban, Population Density, Population Growth, and Infant Mortality Rate by Biogeographical Zone (CIESIN et al. 2004a, 2004b)

\begin{tabular}{lccccc} 
& \multicolumn{3}{c}{ Population } \\
Biogeographical Zone & Population & Urban & Density & $\begin{array}{c}\text { Growth Rate } \\
\text { 1990-2000 }\end{array}$ & $\begin{array}{c}\text { Infant Mortality } \\
\text { Rate }\end{array}$ \\
\hline Humid tropical hill & (thousand) & (percent) & (people/sq. km.) & (percent) & (deaths/1,000) \\
Humid tropical lower montane & 53,940 & 18.2 & 60.2 & 18.6 & 55.4 \\
Humid tropical upper montane & 345,082 & 28.5 & 61.4 & 22.0 & 73.5 \\
Humid temperate hill and lower montane & 12,130 & 52.0 & 74.4 & 22.2 & 35.1 \\
Humid temperate lower-mid montane & 349,308 & 26.4 & 95.9 & 11.2 & 42.8 \\
Humid temperate upper montane and pan-mixed & 79,949 & 37.1 & 57.3 & 5.4 & 29.8 \\
Humid temperate alpine nival & 49,947 & 22.2 & 10.4 & 7.7 & 39.1 \\
Humid tropical alpine nival & 4,426 & 4.7 & 2.8 & 17.4 & 51.1 \\
Dry tropical hill & 1,103 & 18.5 & 8.8 & 14.4 & 39.7 \\
Dry sub-tropical hill & 14,000 & 17.9 & 33.3 & 24.6 & 73.8 \\
Dry warm temperate lower montane & 45,071 & 38.7 & 22.5 & 31.5 & 58.3 \\
Dry cool temperate montane & 43,575 & 35.6 & 33.1 & 24.8 & 60.5 \\
Dry boreal subalpine & 139,405 & 42.8 & 49.3 & 18.1 & 54.2 \\
Dry subpolar alpine & 11,178 & 29.7 & 10.4 & 23.7 & 85.2 \\
Polar nival & 1,317 & 14.2 & 3.7 & 29.8 & 5.8 \\
Total & 10,588 & 13.0 & 2.5 & 19.0 & 48.1 \\
\hline
\end{tabular}

a Difference from Tables 24.8 and 24.9 due to rounding errors.

change considerably, the level of data aggregation often hides these movements. Trends show both increased land use pressure at high elevation as well as increasing trends of urbanization (and a decrease in rural population) (Preston 1996).

In developing countries, mountain populations are generally growing, and some of the highest global rural population densities are found in tropical mountain areas (in Central American and Ethiopian highlands, for instance). This endogenous growth, complemented by immigration, has led to conflicts over land and other resources and the introduction of inappropriate land management practices and invasive alien species. In some mountain areas, such as in Latin America, there is increasing urbanization, with the total number of people in rural areas decreasing over the last two decades.

In industrial countries, one factor that stabilizes populations in mountain regions, or that encourages growth, is tourism, which is increasingly linked to amenity migration (Moss 1994). This phenomenon is becoming evident in many mountain regions. But amenity migrants and other immigrants may not spend all, or even much, of their working time in mountain communities. Indeed, the number of mountain commuters is also growing as travel times to urban and industrial centers decrease. These trends are leading to a blurring of rural/urban populations as mountain areas, and their inhabitants, become more integrated into the mainstream economy in many areas.

\subsubsection{Economic Conditions}

Of the main economic resources of mountains, extractive resources are generally thought to have the highest economic value. National economic policies therefore generally favor extractive industries over other resources and services in mountain areas.

Economic cost-benefit analyses of extractive resources are deficient, however, because they fail to take account of indirect costs or the distribution of benefits that largely accrue to firms and agents located far from the area of extractive activity. Indeed, the opportunities for local people to generate sustainable livelihoods are often restricted. Timber and mining in West Virginia in the United States are notable examples of this (U.S. Census Bureau and Lewis 1998, in Pratt and Shilling 2002). The Grasberg mine of PT-Freeport in Indonesia is a particularly egregious example (Kennedy et al. 1998, in Pratt and Shilling 2002).

Distortions in the distribution of benefits are evident in national accounts data. Foreign investment in Peru, for example, focuses mainly on the mining industry, with projected foreign investment of $\$ 9$ billion for the period 1999-2007. This accounts for about $40-50 \%$ of exports, representing approximately $5.4 \%$ of the gross national product in 1998, and contributing $13 \%$ to government tax revenues (CONITE 1999). Little of this revenue, however, is redistributed to the mountain communities affected in the mining regions. Another example is Western New Guinea (Irian Jaya, Indonesia), a mountainous province rich in natural resources, particularly forests. On a provincial GDP basis, its per capita income is the highest in Indonesia, but its GNP per capita is the lowest. The nearly threefold difference between GDP and GNP clearly demonstrates the level of inequality between total production from the area and the proportion of goods and services that accrues to local residents.

These examples illustrate a general problem in assessing economic and social conditions in mountains: data collection is rarely undertaken on a spatial basis, and this represents a critical gap. Because mountain ecosystems and production systems are closely interrelated, geographically referenced data are essential to enable sound management. Most data linked solely to coordinates have proved to be insufficient for sound decision management. Natural entities, such as geomorphologic units as watersheds, are crucial to understanding processes in mountain regions and should form the basis for management decisions (Bocco et al. 2001). 

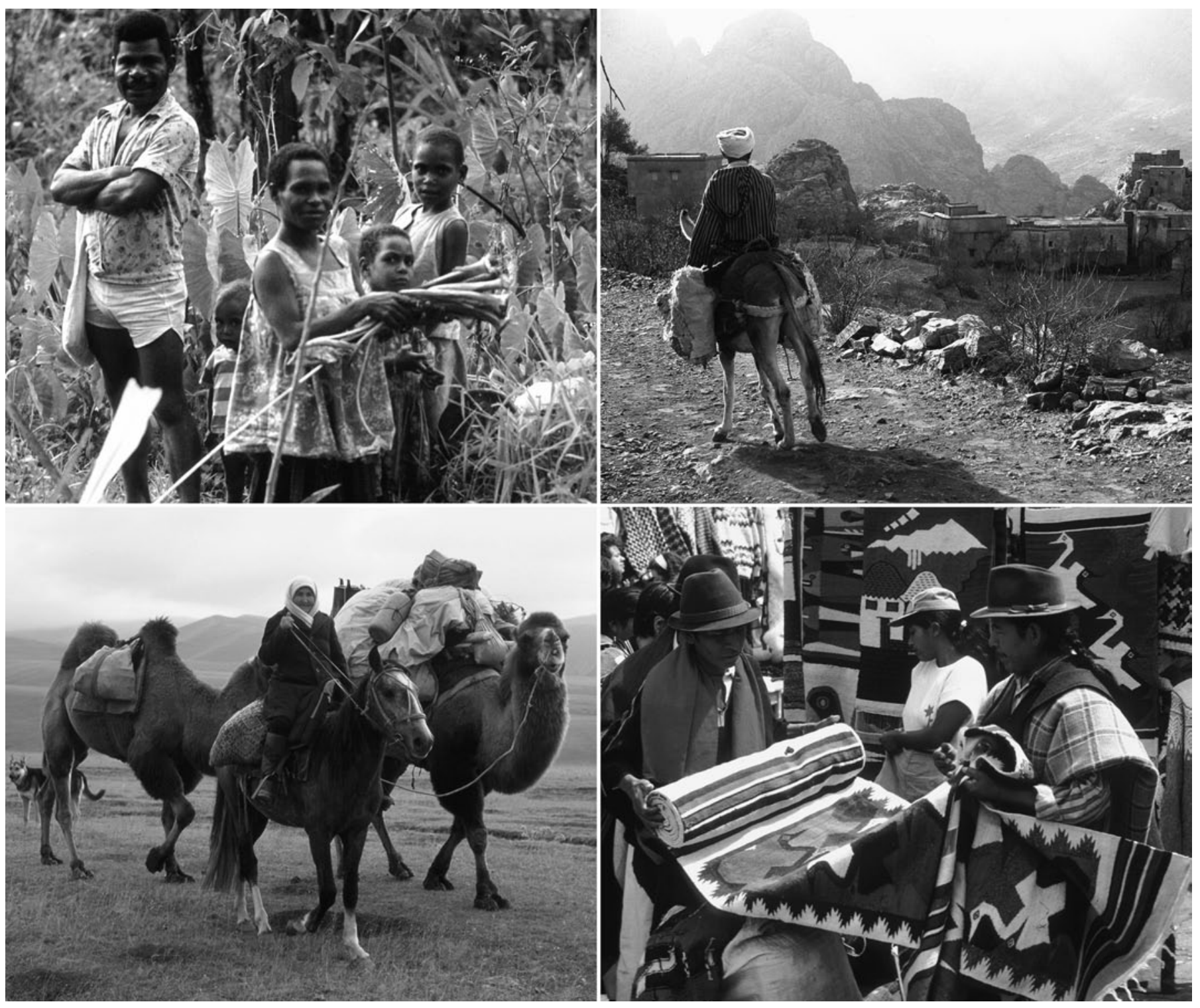

Figures 24.14-17. Mountain People. Top left: Shifting agriculture in montane tropical forests, Papua New Guinea, at 1,200 meters. Top right: Mountain village in the Atlas Mountains, Morocco, at 1,400 meters. Bottom left: Pastoralism in the Tien Shan Mountains, South Kazakhstan, at 2,550 meters. Bottom right: A local market in Otavalo, Ecuador, at 2,000 meters.

Mountain areas tend to have greater poverty and lower levels of development than lowland areas. Starr (2004) noted that, "Poverty has long been a feature of life in many high altitude communities. But the poverty that prevails in many mountain areas today is of a peculiarly modern sort, in that it arises from a growing dependence on lowland metropolitan centers rather than from age-old self-sufficiency in a harsh environment."

Using standard economic criteria, relative poverty in many mountain areas is high-from the Appalachians in the United States to the Amerindians in the Andes and the inhabitants of the Pamirs and Caucasuses in Eurasia. Initial work by the International Livestock Research Institute in Kenya has suggested that mountain areas tend to have relatively high poverty, though the use of relatively low-resolution data does not allow strong conclusions.

The Aga Khan Rural Support Programme and the U.N. Food and Agriculture Organization have each begun to assess mountain poverty (Rasmussen and Parvez 2002; Huddleston et al. 2003). AKRSP found that the status of people in mountain areas reflects the overall level of income of the country in which they live. The higher the national income, the higher the income of mountain people. Yet most available intra-country studies indicate that mountain people do economically less well than lowland populations. There are notable exceptions, however. The mountain areas of the European Alps underwent a rapid economic transformation following improved accessibility. Similarly, traders involved in long-distance trade across some mountain barriers, such as the Himalayas, are quite rich compared with local subsistence farming communities. Noncommercial values such as better access to water, better air quality, and fewer pests such as malarial mosquitoes also add to the benefits of life in the mountains.

Traditionally, dispersion and fragmentation of mountain communities is associated with language differences (for instance, more than 800 different languages in the mountain areas of Papua New Guinea), which further inhibits cooperation on larger-scale activities that could help the improve living standards of mountain people. Mountain roads are expensive to build and maintain, and they generally serve few people per kilometer. A comparison of 
mountain and non-mountain areas in several countries confirms that mountain populations are more isolated, as measured by distance from roads (Huddleston et al. 2003).

Settlement fragmentation in mountain areas makes it difficult to provide basic social services, medical care, or schooling. There is evidence that malnutrition, particularly micronutrient deficiencies, is higher among mountain inhabitants than in lowland populations (Huddleston et al. 2003). Migration provides important - though often socially negative-connections between upland and lowland areas, and remittances constitute an important source of income for mountain families.

Mountain and lowland economies are interdependent today. Lowland populations depend on environmental services provided by mountain ecosystems and people, including watershed protection and recreation. Mountain populations in turn are increasingly affected by global markets, particularly where commodities are concerned-whether these be agricultural products (coffee, tea, medicinal plants), minerals, or hydropower. There is a high level of consensus that the key to achieving sustainable and acceptable standards of living in mountains has been to transfer to local people more control over mountain assets and the means to negotiate more equitable allocations of benefits. In part, this requires improving access to education and health services. This, in turn, depends on building more equitable relations with lowland political institutions and assuring a better distribution of public services. Enlightened self-interest on the part of lowland institutions and well-coordinated actions on the part of mountain people are required to achieve progress in this area.

\subsection{Types of mountain economies}

Almost all adverse environmental and social impacts of economic activities in lowlands have their mountain equivalent. What is different about mountain regions is that the constellation of adverse ecosystem and social impacts is characteristic, rather than exceptional. Anthropogenic impacts often result in permanent, or at least very long-lasting, destruction of biodiversity and productive potential. Given that every mountain range is different in the specificity, complexity, and economic potential of its ecosystem resources and services, methods that help assess the impacts of alternative management choices will need to be developed.

Forest management professionals, mining engineers, policymakers, and environmentalists often face conflicts about how to manage mountain resources. Separating economic values and environmental service values can help management choices. (See Figure 24.18.) In all but one of the cases that follow, actions needed to balance conservation and development interests are quite specific, both in nature and in terms of which actors have primary responsibility.

- Low Export and Low In Situ Value. The Ethiopian highlands, Tibetan plateau, and Andean altiplano exemplify the case of low export and low in situ value, where subsistence farmers have no access to markets and have poor soil and other resources. In such cases, some economic improvement is possible with appropriate technologies, when combined with some restoration of ecosystem functions. Ecosystem restoration is critical, as lowland economies simply cannot absorb the mountain populations that would be forced to migrate in the absence of a viable environment. Downstream populations benefit economically when mountain ecosystems and ecosystem services remain intact. In some cases, if transportation access is provided a region can even shift to high export value if it can find markets for its minerals, timber, or agricultural produce. Even the most minimal transportation access can help communities gain access to local markets. In extreme cases, however, subsidies continue to be justified on humanitarian grounds.

- Low Export and High In Situ Value. In some of the world's most scenic ranges, such as the Cascades Park in North America and Makalu Barun National Park in Nepal, the biodiversity, watershed protection, and recreational values are clear. Low export values may result from inaccessibility to markets, making resource extraction prohibitive; but at the same time the inaccessibility enhances scenic and recreational value. Tourism is a major resource for such mountain economies, and studies in many regions have shown that protection of watersheds provides greater economic value than resource extraction (The Mountain Institute 1998). Conservation is often compatible with tourism, and generates revenue for government in addition to local employment and income. Bhutan and Rwanda, for example, have established high fees, generating substantial funds for conservation and sustainable development. And Nepal and Peru have begun using communitybased tourism to improve livelihoods of local people. However, conservation and the creation of parks and protected areas are not the only choice. Management for sustainable use in agro-forestry-grazing systems has been practiced in the Alps for at least eight centuries. Such systems, however, require strong links to downstream markets.

- High Export and Low In Situ Value. In areas with low biodiversity, where extractive potential is high (mineral resources or hydropower, for example, and managed timber), export of resources is appropriate, such as in the arid mountains of the Peruvian Andes. Adverse environmental impacts can be addressed in environmental impact assessments, provided that mitigating measures and social safeguards are implemented. In practice, however, indigenous communities receive an equitable share of revenues only in exceptional cases, either from corporations or through government programs funded by taxes from the extractive enterprise.

- High Export and High In Situ Value. Areas where extractive potential and environmental benefits are both high, such as in old-growth mountain forests, are classic examples of conflict, with mining in Papua New Guinea often singled out for particular attention. In such cases, decision-makers-corporate, governmental, and civil society-encounter expensive and extended negotiations with stakeholders and are faced with difficult trade-offs in the attempt to satisfy the needs and demands of all stakeholders.

\subsection{Economic contribution of ecosystem services}

Ecosystem services of mountains, often ignored, provide greater economic benefits than extractive resource use in most cases. Intact biodiversity protects watersheds and attracts tourism, as well as furnishing rich natural resources for key industries. When measured, watershed protection values have been found to significantly outweigh extractive resource use.

While mountain people play essential roles in maintaining cultural landscapes and traditions, they may not derive significant benefits from tourism, particularly when most investments come from outside and when revenues leave the area. Governments, nonprofit organizations, and private companies have the potential to ensure benefits to local communities through investments, subsidies, low-interest loans, or training to those involved in promoting tourism and maintaining cultural landscapes and traditions.

The concept of payment for ecosystem services has received much attention in various countries as an innovative tool for the 


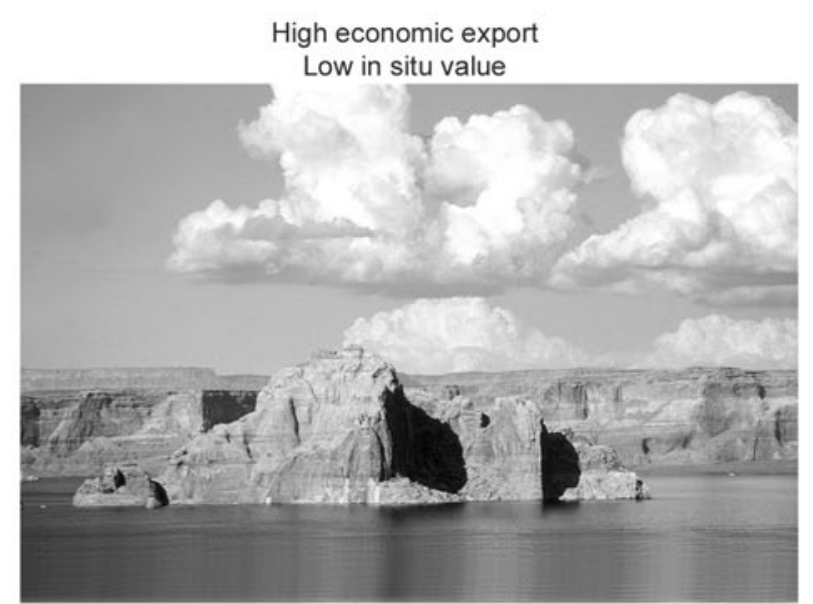

Low economic export

Low in situ value

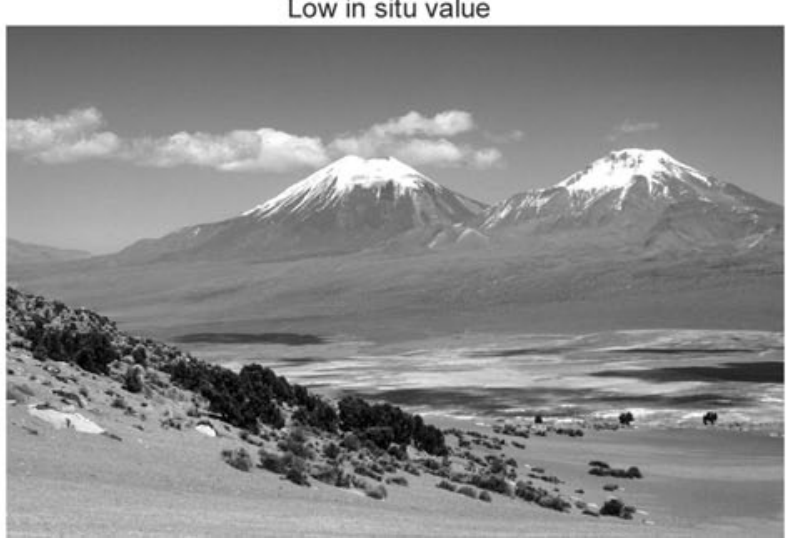

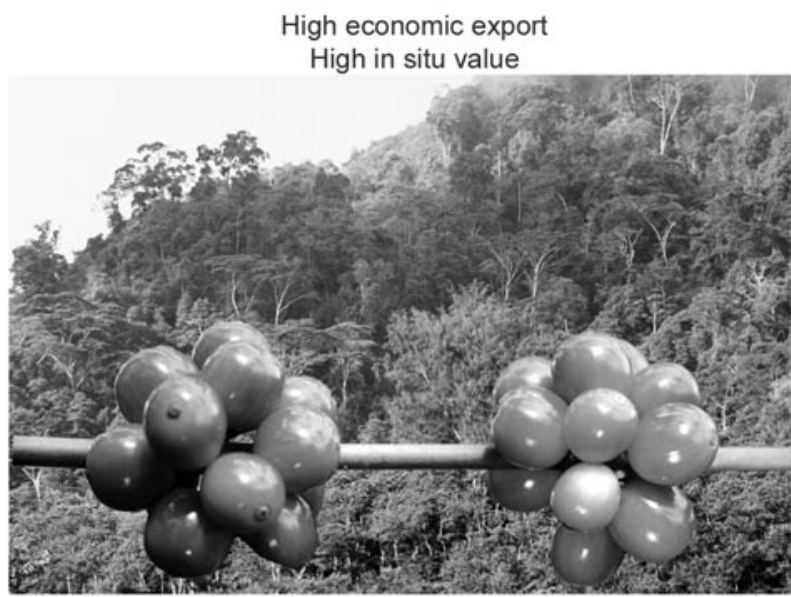

Low economic export

High in situ value

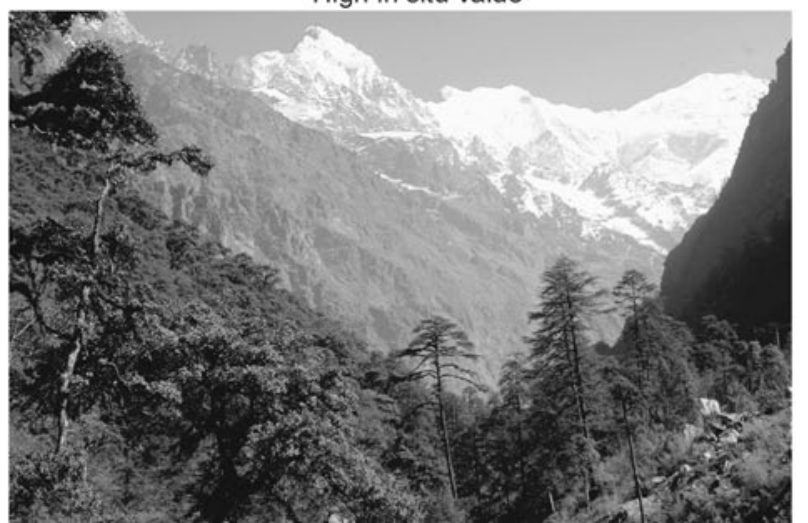

Figure 24.18. A Typology of Mountain Economies. In situ values are ecosystem services provided by the mountain environment in its natural state (such as flood mitigation, water purification, and carbon sequestration. The top left (Lake Powell Reservoir, Utah) represents an area where water existing at high altitudes could be tapped for hydropower or irrigation downstream, but where access problems make it all but impossible for humans to reap economic benefits in situ. The top right (a montane tropical forest in Wau, Papua New Guinea) indicated the main areas of conflict, as represented symbolically by a rich montane forest with shifting cultivation supplying all local needs coming in conflict with a major cash crop, coffee, and the need to clear the forest to grow it. The high, barren landscape in the bottom left (Bolivian Altiplano at 4,200 meters; no export of water, minerals, timber, etc., and marginal local pastoralism) shows that some mountain areas have few natural resources available to inhabitants, and fewer resources that could be profitably exported. A combination of high in situ value but low economic export (bottom right, Langtang valley, Nepal Himalaya; rich forest and gardens at lower montane altitudes, but little to no export) is generally found in areas where lack of access makes export of natural resources too difficult or expensive or where legal or regulatory restrictions have been established that prohibit export of resources, as in national parks.

financing of sustainable management of land and water resources in watersheds. PES schemes consist of a payment or direct compensation by the users to the providers of the service for the maintenance or provision of an environmental service. In watersheds, this usually relates to water supply, availability, or quality. Until now, PES systems in watersheds have been applied at very different stages of the process and for various reasons, from the microwatershed level_focusing on a very specific service-and usually managed by an NGO or local government to national programs controlled by the State.

Recent reviews of PES experiences in Latin America (FAO 2004; FAO/REDLACH 2004) show that such schemes can be sustainable in the long term if they are funded by local resources and if the service as well as the users and providers are well defined. They can contribute to conflict-solving processes by providing platforms for negotiations. Furthermore, they may transfer resources to socially and economically vulnerable sectors in upper watersheds, which offer environmental services. Important limita- tions to the application of the PES concept include the high transaction costs during design and implementation of the scheme (biophysical studies, for instance, and assessment and system installation) and the significant uncertainties regarding the causeeffect relationships between land use and the environmental services, particularly forest-water linkages (FAO 2002b).

Modern transportation gives tourists access to almost all mountain regions. Mountain tourism is very unevenly distributed, however. For example, in the Alps $40 \%$ of communities have no tourism and only $10 \%$ have major tourist infrastructure. Generally, the former are losing population, while the latter have stable or growing populations. Mountain tourism is highly diverse, involving many often seasonal activities, and is highly competitive and sensitive to political tensions. Thus its benefits are unevenly distributed and unpredictable. Flexibility and strategic perspectives are essential, and where income from tourism is reinvested it provides livelihoods for mountain people and helps maintain environmental quality. 
Finally, mountains help protect against hazards (erosion control, slope stability) and contribute to soil fertility (volcanic ashes, carbon fixation), as well as modulating climate through several mechanisms discussed earlier. The vertical upthrust of mountains captures precipitation, often creating rain shadows on one side of the range and wet areas on the other. Seasonal snowpack melting and mountain bog ecosystems are critical sources of water for agriculture as well as for drinking water.

The economic impact of these climate-modulating effects is taken for granted and implicitly factored into the costs and benefits of water use. Major changes in the ability of mountains to provide such environmental services, however, would create significant and potentially disastrous cost increases. For example, the retreat of glaciers caused by climate change is likely to cause shortterm increases in water availability, leading to increased investments in irrigation and enabling the growth of downstream cities. In the medium term, however, the water supply from meltwater is likely to be markedly reduced if glaciers continue to recede, negating the value of massive infrastructure investments.

\subsection{Extractive industries and public utilities}

Mountains provide the largest share of resources for mining, forestry, water for drinking and irrigation, and hydropower, and they generate an increasing amount of wind power as well.

Water is becoming a limiting constraint to development in many parts of the world, and in some cases to life itself. The critical importance of mountain ecosystems in regulating water quality and quantity cannot be overstated. In addition, the specific economic value of hydropower depends largely on mountain water, which in turn depends on conserving mountain watersheds.

Some $6 \%$ of the world's energy and $15 \%$ of its electricity is produced from hydropower. Aside from a few hydropower projects built on swiftly flowing rivers that require no dams, most hydro projects inundate large areas for reservoirs. In mountains, the massive weight of such holdings creates a risk of induced seismic events and dam failure, sometimes resulting in catastrophic flooding. The benefits of hydropower-in terms of access to electricity and profits - accrue mostly to the lowlands. Those in mountains often suffer losses from inundation, diversion of water flows, and disruption of traditional production.

Yet mountain communities and downstream beneficiaries share a common interest in protecting upstream watersheds to assure continued productivity of both hydropower sites and upland production systems. This has proved to be one avenue to joint stewardship arrangements. Properly managed, water supply and hydropower can be a sustainable use of mountain resources. But extra efforts are usually needed to ensure that mountain people get a fair share of benefits and, in the case of hydropower projects, a connection to the power grid.

Globally, forests are probably the second most important economic resource provided by mountains, although this varies across mountain regions. Since most logging is done in pristine forests, little or nothing is paid for production costs. However, standing timber also provides valuable services-stabilization of water flow, protection of biodiversity, carbon sequestration, provision of amenities, and many non-timber products. Several studies have calculated that the economic value for such services exceeds that of the timber extracted. Harvesting primary forests is therefore like mining a resource without compensatory reinvestment. And as with hydropower and mining, many of the economic benefits do not remain in the region that provides the resource.
The loss of trees significantly alters the ecosystems of mountain areas and leads to the loss of alternative sources of incomenon-timber forest products, biodiversity, tourism, and so on. Losses of ecosystem benefits are often hard to measure, however, as they are not priced or traded in markets. But some local studies have shown that such benefits often far outweigh the value of timber from logging. In Indonesia, for example, the value of alternative uses exceeds the value of logging by more than $50 \%$ (Conservation International 1999).

Communal forestry is a critical element in integrative participatory forest management in many regions. In large parts of mountainous areas in Latin America, Africa, and South and Southeast Asia, collective forest management has proved to be a successful alternative to government or commercial control. Policies that undermine these collective systems have promoted the abandonment of traditional farming systems, often with large, adverse environmental consequences.

Mineral extraction contributes a relatively small part of global GDP, but mineral revenues are often important in mountainous countries. Minerals account for $45 \%$ of Chile's exports, $49 \%$ of those from Peru, 64\% of Zambian exports, and 62\% of Papua New Guinea's. While some of the world's largest and most productive mines are found in low-lying areas, mines tend to cluster along mountain ranges. An exception is the Himalayan area, which is not yet cluttered with mines, where ruggedness and distance from markets-in addition to strong local oppositionmakes it harder to justify mining operations. Cases in the Supreme Courts of India and Nepal against mining in the fragile Himalayan watersheds drew attention to the risks of mining in these areas (Bandyopadhyay and Shiva 1985). China is nevertheless expanding exploration in some areas on the northern side of the Himalaya.

Mines are nearly always highly destructive to the local environment and displace people living in the immediate area (Pratt 2001). More threatening still are the pollution and toxic wastes produced or accidentally released by mine operations. Toxic pollution from mines has often been recorded leaching out and contaminating large areas downstream, especially in developing countries.

There is a high level of consensus that significant benefits are obtained from better stewardship of upland resources and the appropriate reinvestment of profits from extractive industries into resource management in a way that benefits local communities. For instance, the Sierra Nevada in California produces some $\$ 2.2$ billion per year in commodities and services. Water resources constitute $61 \%$ of the total, yet reinvestment in watershed management is basically zero, since water rights are not taxed as property, and commercial real estate assessments are low compared with revenues generated. In contrast, recreation and residential use provide $21 \%$, timber $14 \%$, and grazing $2 \%$ of total value, but reinvestment amounts to $\$ 10$ million, $\$ 23$ million, and $\$ 7$ million (in the latter case, as subsidies) (The Mountain Institute, Investing in Mountains, 1997).

Mountain farming systems involve multiple land use activities and diversified production systems that adapt/amend the natural resources (such as through water harvesting or terracing). This has resulted in diversified and context-specific farming systems characterized by positive social system-ecosystem links. In nearly all mountain regions, non-timber forest products are an important adjunct to traditional agriculture, often providing the sole or major source of medicine for local people, as well as supplying key nutritional supplements. With globalization, the production of nuts, fruits, off-season vegetables, flowers, and cosmetic and medicinal plants has opened new economic opportunities for 
mountain communities. However, the value added by mountain dwellers will likely remain proportionally small unless local processing replaces the export of raw produce (Jodha 2002).

With closer integration of mountain and lowland economies, enhanced administrative interventions, and population growth, the connection of mountain communities to natural resources has declined (Berkes and Folke 2002). Increased poverty, inequity, and dependence on external support in most areas is a major consequence. Interventions to address such problems have not proved effective because they lack a mountain perspective- that is, sensitivity to mountain-specific conditions that take into account the fragility, marginality, limited accessibility, and diversity of mountain systems. Based on studies in developing countries, the International Centre for Integrated Mountain Development has identified over 50 indicators of unsustainable mountain agriculture and resource use that are emerging in these areas (Jodha 2001). These range from reduced crop productivity to a decline in the range and quality of sustenance options (excluding areas with better access and infrastructure, and where inaccessibility encourages cultivation of illicit crops). These trends are likely to accelerate as market forces gain primacy.

The rise in global demand for mountain herbs and other organic and non-timber forest products is leading to over-extraction. Disregard of customary rights, collective risk sharing arrangements, and reduced social transfers (subsidies) have increased vulnerabilities. While some mountain areas have benefited from the process, others have to face the deleterious effects of globalization (Jodha 2000). In general, agricultural production systems in mountain areas are likely to be driven and controlled by market forces rather than people's sustenance needs and preferences.

\subsection{Relationships between drivers and changes in ecosystem condition}

All the impacts just described are exacerbated by the development of modern economic infrastructures, such as highways and communications towers that interrupt conservation corridors, reduce scenic values, and contribute to erosion and pollution from traffic. Although roads reduce remoteness and inaccessibility of highland communities, inappropriate siting, construction, and maintenance often have serious adverse impacts in steep upper watersheds (Cassells 1996; Hamilton and Bruijnzeel 1997). Location in landslip- or landslide-prone environments creates both on-site and downstream sediment problems. Roads run the risk of crossing groundwater aquifers, altering hydrologic stability and interfering with water supply for both upstream and downstream watershed residents. Sealed surfaces enhance runoff, increasing the risk of flash flooding. Cut-and-fill situations are particularly erosionprone. Soil erosion problems demand frequent and costly maintenance. To lessen hazards, the construction of underpasses and overpasses for road users and animals has proved effective. Construction or mining camps or towns for workers create environmental disturbances and also serve as a major vector for $\mathrm{HIV} /$ AIDS and other diseases.

\subsection{Implications for human well-being}

This assessment indicates that when full costs are taken into account, stewardship of upland resources generally yields greater and more sustainable economic returns both to the people living in the mountain areas and to the immediate downstream economies when compared with extractive activities, in cases where there is competition between the two. For mountain communities, protecting the ecosystem that they depend on requires interventions: regulatory protection has a high potential to ensure that full costs are included in project design and implementation, and promoting solid links between upstream and downstream markets creates economic opportunities that generate mutual benefits. In the long term, there is a consensus that upland and lowland ecosystems, and the economic resources and services they provide, depend on populations in both regions supporting stewardship of mountain environments. The challenge for investment and policy action has been to bridge short- and long-term interests.

The failure to protect and manage mountain resources sustainably has dire consequences that become visible only when it is already too late. Among the most important economic consequences are impacts on employment and sustainability. Conservation programs that protect environmental services have been shown to create employment for local people and, in the best cases, to strengthen cultural identity and security (for example, the UNESCO Biosphere Reserve concept). Mismanaged conservation programs can drive local people out by force or when competition for land and housing drives up prices. Those driven out tend to place burdens on nearby urban areas through unemployment and demands for public services. They are often considered "different" from local people, contributing to discrimination and ethnic violence.

Extractive industries are particularly problematic in mountains. Hydro projects frequently disrupt aquatic ecosystems but rarely offer long-term jobs for local people. Forestry provides greater local job opportunities, but mountain forests regenerate slowly or not at all, and employment disappears once the timber is gone. The loss of forest also eliminates traditional lifestyles that use hunting, fishing, and non-timber forest products to supplement farming. Mining has serious environmental consequences; but modern mining often provides scant local employment. Mining companies have shown increasing willingness to provide social services, but the benefits tend to last only until the mine is exhausted, while environmental damage is persistent.

Greater attention to conservation and to strengthening traditional production systems has the potential to generate greater economic value. Managing trade-offs among uses is often limited because most data on resource extraction and ecosystem production and services are not spatially referenced, masking the contributions of mountain regions, and leading to ecosystem degradation and economic inequities. The availability of spatially referenced data is thus a critical gap.

\subsubsection{Cultural Issues}

Many mountain communities are ethnically or culturally distinct from lowland populations, and local highland communities are often highly distinct from each other. The significance of mountains for human cultural diversity is demonstrated by the great ethnic and linguistic diversity of some mountain regions, such as the Caucasuses, the Himalaya, and the mountains of New Guinea (Association des populations des montagnes du monde 2003). Indigenous mountain populations often exhibit genotypic physiological adaptations to altitude (Beall 2002).

In mountain ranges throughout the world, traditional cultures and conservation have evolved together over the ages. Sustainable natural resource management is driven by the beliefs and behaviors of human communities, and local cultures are strengthened by their intimate connections to the natural environment that sustains them. Sacred and spiritual values are thus integral to mountain cultures; mountains are considered sacred by more than 1 billion people (Bernbaum 1998). (See also Chapter 17.)

The value of place-based mountain cultures today is in their continuing stewardship of watersheds and other mountain re- 
sources and in the wisdom they have to impart regarding the requirements for sustainability of mountain ecosystems (Pratt 1998). A major cultural element of life in the mountains is tied to animal husbandry, which also is by far the most influential form of land use (in terms of area). Quite often this involves the use of fire (Price 1999). The U.N. Commission on Sustainable Development has stated that "support is needed to recover and foster the cultural expression of mountain populations because mountain cultural diversity is a strong and valid basis for sustainable use and conservation of mountain resources" (Commission on Sustainable Development 1995). And the need to protect and support the cultural diversity of mountains has been emphasized in the declarations of numerous major international meetings (e.g., Association des populations des montagnes du monde 2003).

\subsection{Drivers of Change in Mountain Systems}

Environmental and economic change is a constant and familiar factor in mountains, but the magnitude and rate of change and its influence on social systems in recent times threatens to overwhelm mountain ecosystems - with serious consequences for the well-being of mountain communities as well as hundreds of millions of people downstream. Mountain systems are changing more rapidly than at any time in human history. The core issue is that more than half of humanity depends on mountains for water to drink, to grow food, to produce electricity, and to generate industry. In addition, mountain ranges represent important challenges for transportation, communications, and access.

Natural forces such as volcanic and seismic events, landslides, and flooding devastate large areas of mountainous ecosystems every year. Such changes, though vast and visible, are nevertheless dwarfed by deleterious anthropogenic changes, such as intensification of land use and overexploitation of natural resources (Messerli and Hurni 2000; FAO 2002a; Pratt and Shilling 2002).

\subsubsection{Direct Drivers}

Because mountains are formed by tectonic forces, it is not surprising that mountain regions are particularly susceptible to damage from earthquakes and volcanoes, which in many cases results in a significant loss of life and property. Climate change is another direct driver with special significance for mountains and serious implications for human well-being. Mountains are particularly susceptible to climate change because their biota are adapted to specific often narrow altitudinal zones, and diseases have proved to be able to move more quickly than plants and animals can adapt. Conversion of land in mountains, largely through pasture practices, the use of fire, and animal husbandry is another major driver.

Large-scale mining can massively overburden steep terrain, and often pollutes streams and damages aquatic and other wildlife. Construction of roads in mountain areas often leads to slope instability, land slides, and erosion. The large-scale building of vacation homes and resorts has had mixed impacts in mountains, while in many regions, out-migration of mountain farmers has led to reforestation and loss of alpine pastures. Elsewhere, forest is cleared for commercial timber. Such loss of vegetative coverregardless of the cause-can have a significant adverse impact on water quality and quantity both in mountain regions and below. Threats to human well-being from these drivers range from increased risk of avalanche to loss of income from tourism.

These drivers of change are not new-there are historical accounts of human impacts on mountain environments, with drought and famine, dating back millennia (such as the felling of mountain cedar forests in Palestine and Lebanon 5,000 years ago). Forest destruction continues, however. Major drivers of the direct anthropogenic impacts are the lack of public awareness and knowledge and indirect socioeconomic forces.

\subsubsection{Indirect Drivers}

Indirect drivers affecting mountains can be complex. In mountain areas from Jamaica to Nepal, mountain forests are destroyed as population increases in the lowlands, forcing poorer people into the mountains, where they cultivate marginal land for subsistence. Economic development often results in land use changes such as those just described, with consequent degradation of ecosystem services. More difficult to measure, but nonetheless important, economic development in mountains usually leads to a weakening of traditional cultures and religions that have provided the underpinnings for local sustainability.

Science and technology, on the other hand, have frequently had positive impacts in mountain areas and have the potential to provide solutions to a number of critical problems. Solar and wind energy, and especially small-scale hydropower, have brought enormous benefits in regions where they have been introduced and where extension of transmission lines is otherwise prohibitively expensive. Information technology is perhaps the single most promising technology for mountain communities, with potential to overcome access barriers that currently limit educational opportunities for tens of millions of mountain families.

The sectorally based organization of governments hampers the implementation of more holistic or ecosystem-based approaches to mountain ecosystem management (Rodgers 2002; Pratt and Shilling 2002). Overall, flawed institutional responses (lack of mandates, policies, and political will) are pervasive indirect drivers of change in mountains. The lack of structural mechanisms that can deal holistically with mountain areas has made it difficult or impossible to prevent or mitigate adverse impacts of key drivers. This can be seen in the lessons from decades of mountain water conservation initiatives that have generally failed due to sectoral fragmentation of institutional responsibilities, political interference, over-reliance on technocrats at the planning stage, too little involvement of landowners and local communities, an overemphasis on maximal instead of sustainable resource use, and a lack of knowledge on adequate farming systems (many introduced systems were originally developed for lower altitudes).

Other indirect drivers are the lack of public awareness, lack of real valuation of resources and services, and lack of knowledge transfer. Empowered and well informed local communities have proved to be key to managing changes imposed from outside; in the case of biodiversity, a functional network of protected areas is an essential starting point for genetic reservoirs and monitoring stations (Dhar 1997).

For many drivers, indicators and monitoring programs are in place, like the recent worldwide installation of monitoring sites in mountain summit regions - the Global Observation Research Initiative in Alpine Environments (Pauli et al. 2004, 2005). What is missing is the sociopolitical and economic understanding of how scientific insights can be applied and how local stakeholders can be involved on a continuing basis.

\subsubsection{Property Rights to Mountains}

In most mountains outside Western Europe and the United States, legal ownership of the land is retained by the state. Mountain lands are also covered with customary use rights for members of local communities (de facto ownership). Major challenges for resource governance in many parts of the world include encour- 
aging governments to recognize customary rights and finding ways of recording and enforcing such rights. (See Box 24.4.) Over a dozen countries have enacted specific legislation related to mountains (Lynch and Maggio 2000).

Property rights to mountains are often poorly defined because mountain areas for most of history have been seen to contain few resources. Now, however, market forces are reaching into remote mountain communities, and government interest in managing ecosystems and their services has increased. Indigenous (or noncapitalist) cultures have usually developed customary law similar to property rights for specific material resources. Property rights claimed by the state have led to discrimination against indigenous peoples in some parts of the world, making their customary rights harder to defend.

The early modern states tended to pursue a policy of bundling "ground," "remainder," and specific resources (see definitions in Box 24.5) into one owner unit in their legal systems. This "dominium plenum" position on ownership and its assumed beneficial economic consequences led to the processes of enclosure and land consolidation. Applied to mountains and other areas where local people were interested only in specific resources and socio-

\section{BOX 24.4 \\ An Institutional Definition of Property Rights}

Property rights provide legitimate allocation to particular owners, with material or immaterial objects supplying income or satisfaction to the owner. They comprise a detailed specification of rights and duties, liberties, and immunities citizens have to observe. These are defined partly by law and partly by cultural conventions, and they are different for owners and non-owners. Property rights are ultimately guaranteed by the legitimate use of power.

The dynamics and performance of economic systems are intimately linked to the kind of property rights a state is able to enforce.

\section{BOX 24.5}

\section{A Legal Definition of Resources (Black 1990)}

The technical details in the specifications of property rights are many and are important to the dynamic of the economy. They are changing through time and across space and are in general moving toward greater diversity and more detail. For management purposes, legal reasoning will divide resources into 3 types:

- the ground (sometimes called the soil), meaning the abstract bounded area;

- the specific material resources embedded in the ground, attached to the ground, or flowing over the ground (in general there are limits on how far into the ground and how far above the ground the rights reach); and

- the remainder, meaning the future interest in resources not yet discovered or not yet capable of being exploited.

These three types of resources are usually included in discussions of who owns what and are routinely recognized by mature legal institutions. Landlords are, at a minimum, owners of the ground and are then entitled to the ground rent. It must be emphasized that in principle there may be different owners to the ground, to every single wellspecified resource, and to the remainder. cultural symbols, this practice has tended to create conflicts, most notably for timber and other commercially valued resources.

Social and technological change creates new specific resources usually seen as belonging to the owner of the remainder (such as the generation of hydroelectric power), and this also leads to new regulation of ecosystem services. Such developments often conflict with customary use rights. Thus the potential for conflict is rising and is often precipitated by government interventions-for example, to protect mountain resources. Since states have made little or no effort to enforce their claims to property rights (except for timber, hydroelectric power, and mining rights), most customary uses have continued more or less uninterrupted. While the viability of local cultures depends on traditional resource use, it has often proved hard for mountain people to get recognition of their de facto and customary property rights. It should also be noted that customary systems of rights are vulnerable to the impact of market forces. For instance, the makers of local rules may respond too slowly to rapid changes in harvesting of local resources that have acquired market value.

Current trends in international law put greater emphasis on de facto rights as these are expressed in customary uses of an area (such as ILO Convention 169 concerning Indigenous and Tribal Peoples in Independent Countries). International conventions on human rights and indigenous peoples have sought to award property rights (by implication, probably in the dominium plenum tradition) to those who have, through traditional usages of an area, established use rights to specific resources.

Statistics on ownership of mountain resources do not yet exist for the world as a whole. Neither do available sub-regional figures conform to ecological boundaries or to social realities of mountain communities. Furthermore, publicly available statistics on property rights only report de jure rights. The plethora of de facto use rights is often found in separate records, if they are recorded at all.

Most land registers are based on the dominium plenum ownership concept and only register owners of the land itself (not its use). Even if approximate figures for de jure owners were collected (nations, local states, towns, collectives, or individuals), the lack of reliable information on de facto ownership of specific resources would make the presentation of de jure figures more misleading than helpful. Developments in international law, such as ILO convention 169, have tended to put emphasis on de facto possession rather on de jure claims. (See Box 24.6.) Theoretical developments in the management of complex resource systems tend to support the allocation of a high degree of autonomy to local user groups protected by property rules.

Starting with the Roman law assumption that all lands have a landlord, medieval states in Europe tried to gain control of nonarable lands. Unclaimed lands became crown lands. In many cases the early modern states (notably Sweden, Germany, and France) introduced state ownership of forestlands and strengthened the state control of the lands without owners. The result was often state ownership of mountains.

"New nations" (including the United States) have at least since 1776 routinely claimed state ownership of unimproved lands. "Improvement" (such as industrial activity or agricultural use of arable land) was needed to justify privatization. This "improvement" policy for awarding title to land has in most cases led to state property rights to mountains. Socialist states in 1917-89 routinely nationalized land. In the restitution period after 1989, many of these states either neglected to include mountain areas (outside settlements) in the process or expressly reserved these areas for state control. Likewise, many new nations created through decolonization since 1945 have nationalized land, or at 
BOX 24.6

\section{Emerging Collectively Owned Resources}

Environmental legislation is at the outset independent of ownership, but it is increasingly seen to change the meaning and content of ownership by defining and taking control over two additional types of resources that can be seen as emerging from the remainder:

- ecosystem services, such as water control, disaster mitigation, local climate control, biodiversity, and so on, and

- sociocultural symbols vested in a landscape (often attached to amenity and heritage sites).

Ecosystem services are usually managed through government regulations. Sociocultural symbols are created and sustained by the local culture but now increasingly taken over by national and international bureaucracies. (See Buck 1996 and Lowenthal 1985 for more about environmental management and sociocultural symbols.)

least unimproved lands. Mountains and less accessible land or lands assumed to be less valuable have tended to remain in state ownership even where other lands were privatized.

\subsubsection{Wars and Other Conflicts}

In 1999, 23 of the 27 major armed conflicts were in mountains (FAO 2002a). Due to their usual situation of relative inaccessibility and remoteness from centers of population and government, mountains are often used by those who wish to escape the established authority. In countries where there are guerrilla movements or rebels, it is the mountains that are often their sanctuary (as in Afghanistan, Chechnya, and Colombia), and many illegal drugs are produced from crops such as coca, poppy, and marijuana grown in highland regions.

For most of the past 500 years, the main source of conflict in mountainous countries was the effort of emerging states to extend their power over mountain peoples. Starr (2004) states "Any government that thinks it can bludgeon mountain people into submission is engaging in a most destructive form of self-deception. The sense of territoriality, independence and cohesive social (often clan) relationships formed in isolated upland valleys are perfectly suited to sustain conflicts over the long haul."

Mountain ranges are often borders between nations or other political jurisdictions. Tensions along borders are common, and in some cases the location of the border has been in dispute, such as in the Peru-Ecuador conflict of 1995 in the Cordillera del Condor (Peace Parks in this area are described in the next section). Many conflicts have also arisen over natural resources in mountains, often based on issues of property rights, such as over logging on customarily used lands. The Chipko forest conservation movement in the Himalayas is a good example of such a dispute (Bandyopadhyay 1997).

\subsubsection{Mountain Protected Areas}

\subsubsection{Global Network}

Biological diversity, water resources, soil, and geological, cultural, and spiritual values of mountains are all maintained best in some kind of protected area situation. Protected areas in this sense are those without unbridled exploitation, where some degree of restraint is required in human use in the interest of natural or metaphysical values. IUCN-the World Conservation Union defines protected areas as: "Areas of land and/or sea especially dedicated to the protection and maintenance of biological diversity, and of natural and associated cultural resources, and managed through legal or other effective means" (IUCN 2000). As of 2003, there are 102,000 of these sites, covering 18.8 million square kilometers, or roughly $11.5 \%$ of the world's terrestrial surface (Chape et al. 2003). They span many kinds of situations, with varying degrees of human intervention-from wilderness areas and national parks to multiple use areas and lived-in protected landscapes. The IUCN category system is shown in Table 24.11.

\subsubsection{The Mountain PA Situation}

Mountain PAs are well-represented in the global network, even though there is some ambiguity over what constitutes a "mountain" PA. The U.N. list for 2003 shows 9,345 mountain protected areas covering 1,735,828 square kilometers in the "mixed mountain systems" biome defined by Udvardy (1975); therefore about $16 \%$ of this biome is protected (Chape et al. 2003). Thorsell (1997) showed that the highest elevation Pas-based only on IUCN categories I-IV, minimum relative relief of 1,500 meters and minimum size of 10,000 hectares - had a good distribution throughout the biogeographic realms. (See Table 24.12.)

The Thorsell assessment covers "high mountains" and those with a minimum of human land use modification, though many of them do have quite intensive visitation by tourists, mountaineers, and hikers. They are most often in the ownership or under the control of some level of government.

The importance of the PAs in the remaining categories (V and VI, Table 24.11) must not be discounted. Grazing, forestry operations, and many kinds of agronomic use such as orchards, vineyards, and terraced annual crops can be conducted in nondestructive and non-resource-polluting ways. In addition, important cultural values are often maintained in mountainous protected landscapes. Agro-biodiversity, as well as much wild native biodiversity, can be conserved if sustainable land uses are in place.

Table 24.11. The Six IUCN Management Categories of Protected Areas (IUCN 2000)

\begin{tabular}{|c|c|c|}
\hline Category & Name & Description \\
\hline I a & Strict Nature Reserve & $\begin{array}{l}\text { protected area managed mainly for } \\
\text { science }\end{array}$ \\
\hline $\mathrm{lb}$ & Wilderness Area & $\begin{array}{l}\text { protected area managed mainly for } \\
\text { wilderness protection }\end{array}$ \\
\hline II & National Park & $\begin{array}{l}\text { protected area managed mainly } \\
\text { for ecosystem protection and } \\
\text { recreation }\end{array}$ \\
\hline III & Natural Monument & $\begin{array}{l}\text { protected area managed mainly for } \\
\text { conservation of specific natural } \\
\text { features }\end{array}$ \\
\hline IV & $\begin{array}{l}\text { Habitat/Species } \\
\text { Management Area }\end{array}$ & $\begin{array}{l}\text { protected area managed mainly for } \\
\text { conservation through manage- } \\
\text { ment intervention }\end{array}$ \\
\hline V & $\begin{array}{l}\text { Protected Landscape/ } \\
\text { Seascape }\end{array}$ & $\begin{array}{l}\text { protected area managed mainly for } \\
\text { landscape/seascape conservation } \\
\text { and recreation }\end{array}$ \\
\hline VI & $\begin{array}{l}\text { Managed Resource } \\
\text { Protected Area }\end{array}$ & $\begin{array}{l}\text { protected area managed mainly for } \\
\text { the sustainable use of natural } \\
\text { ecosystems }\end{array}$ \\
\hline
\end{tabular}


Table 24.12. Mountain Parks (High Mountains)

\begin{tabular}{lcc}
$\begin{array}{l}\text { Biogeographical Realm } \\
\text { (Udvardy classification) }\end{array}$ & Parks & Total Area \\
\hline & (number) & (mill. hectares) \\
Afrotropical & 42 & 20.4 \\
Antarctic & 15 & 3.2 \\
Australian & 3 & 2.6 \\
Indomalayan & 42 & 7.2 \\
Nearctic & 96 & 153.8 \\
Neotropical & 103 & 34.5 \\
Oceanian & 8 & 3.6 \\
Palearctic & 164 & 39.1 \\
Total & 473 & 264.5 \\
\hline
\end{tabular}

Water and soil resources can also be safeguarded by proper husbandry of forests and agricultural lands.

Most of this nature-friendly management will be carried out by private landowners or communities, often using traditional practices that have proved their sustainability over generations. Some are in national and state forest management areas or community forestry units. As wild areas, even in the mountains, succumb to development, much of the hope for maintaining biological and cultural diversity in mountain environments rests in proliferation of Category $\mathrm{V}$ and $\mathrm{Vl}$ areas of protection. And as secular forces erode ancient cultural belief systems, mountains once protected de facto by reverence, awe, or taboo need to come under formal secular protection in all kinds of PAs. Geological heritage is often protected in the Natural Monument Category, though "geoheritage" is under-represented in the world network.

\subsubsection{International Designations}

Many Protected Areas are also designated as UNESCO Biosphere Reserves, where core zones of more strict preservation are buffered by zones of conservation use, in which sustainable land uses are promoted. Scientific research on ecosystem functioning and human-environment interactions are carried out in these reserves. As of 2003, there were 436 Biosphere Reserves (Chape et al. 2003), at least 190 of which were in mountain areas (UNEPWCMC 2002).

Some mountain PAs are of such global significance that they have been placed on the World Heritage List of UNESCO. This designation is reserved for areas of universal value. There are 88 natural World Heritage Sites and 16 mixed (natural and cultural) ones in mountain areas (UNEP-WCMC 2002). For high mountains, Thorsell and Hamilton (2004) reported on 57 existing World Heritage Sites and identified 28 other potential sites to help fill the gaps in coverage.

\subsubsection{Weaknesses in Protected Area System}

A major weakness in the mountain PA global system is that most of the units are discrete, covering single mountains. Connectivity between these "sky-islands" is badly needed along the ranges or in biogeographic clusters. Linkages through a landscape of conservation corridors can effectively enlarge the PA, providing better protection of the full suite of biodiversity, including "umbrella" species such as large wide-ranging carnivores. Moreover, such connectivity would provide greater insurance for migration of species and genes in the face of climate change. A number of these corridor initiatives are now in place, such as the 3,200-kilometerlong Yellowstone-to-Yukon corridor in the U.S. and Canadian Rockies and the Condor Bioreserve constellation in Ecuador.

Unfortunately, many mountain PAs were established to protect the scenic high peaks of local or national value as cultural icons or for mountaineering and tourism. Biodiversity values were not considered, and the PAs often conserve mostly rock, ice, and snow or upper montane forests and alpine meadows. Many are too small to accommodate serious natural or human disturbance or to embrace much mountain biodiversity.

The challenge is to enlarge these areas, in particular to extend them to lower elevations to achieve species, genetic, and community conservation and provide functional landscapes for wideranging species. Expansion and connection from summits to lowlands is also a "must" for climate change response-for instance, the corridor from the Royal Manas Tiger Reserve in the tropical lowlands of India through a series of parks and conservation areas in Bhutan up to the crest of the Himalaya in Jigme Dorji National Park, Bhutan. There are at least 36 such initiatives around the world in mountains areas.

\subsubsection{Transborder Parks in Mountains}

Since many national or sub-national borders follow mountain ranges, many mountain protected areas abut such borders and each other. There are approximately 169 complexes of internationally adjacent protected areas (Zbicz 2001). About 42 of these are in mountains. These offer good opportunities to carry out cooperative transborder planning and management to better conserve shared biodiversity and water resources and to fight fires, pests, and non-native species-none of which recognize political boundaries (Hamilton et al.1996). As indicated earlier, these offer opportunities to reduce tension and conflict between neighboring countries, as Peace Parks.

\subsubsection{Effective Management and Monitoring of Protected Areas}

The World Commission on Protected Areas of IUCN has an active Task Force on Management Effectiveness, and it has developed criteria and standards for more effective management of protected areas. Baseline data and monitoring are sorely needed as a basis for adaptive management. Far too many protected areas are "paper parks" without effective protection and little management. The IUCN World Commission on Protected Areas has recently produced a set of "Guidelines for Planning and Managing Mountain Protected Areas" (Hamilton and McMillan 2004) to help rectify this situation.

\subsection{Trade-offs, Synergies, and Management Interventions in Mountain Systems}

\subsubsection{Highland-Lowland Interactions and Their Trade-offs}

Until recently, the economic importance of mountains was generally ignored (with the exception of supplies of some minerals, timber, and water), and little attention was paid to local environmental, socioeconomic, and cultural issues. With the U.N. Conference on the Environment in 1972, changes in mountain landscapes - including deforestation, accelerating slope instability, earthquakes, landslides, and floods_-began to be highlighted, but the focus was mainly on the potential destructive impacts on lowlands originating from the mountains. 
These early and simplistic perceived linkages between highlands and lowlands fell into two categories: physical processes under the influence of gravity and the exploitation of mountain resources to satisfy the needs of lowland residents.

Highlands and lowlands have widely different resources and production opportunities. This forms a natural basis for complementary economic links between them. In practice, however, the relationship has been more often characterized by inequitable power relationships, although highland communities can have significant effects on the power structure and way of life of far distant lowlands.

There are often competitive demands on mountain resources-increased resource extraction reduces the extent and value of environmental services that ecosystems can provide. Conversely, preserving ecosystem services may reduce incomes for particular interest groups. Furthermore, the relative value placed on mountain resources depends on technological developments and shifts in the world economy. In developing countries, this often creates a bias for exports, and in most mountain regions it creates a bias for extraction rather than conservation of resources.

Several factors affect the highland-lowland links:

- limited accessibility, isolation, semi-closed situation created by slope, terrain conditions, and permanent underinvestment in addressing the problem, all of which adds to the cost of logistics and other support systems to harness production opportunities and their competitiveness and equitable trade, although in some cases limited accessibility can be tied to tourist attractions (in the Everest region, for example);

- fragility - a product of slope, soil factors, and so on - which not only prevents intensification of land resources use for high productivity but obstructs infrastructure development to improve accessibility to facilitate mobility and trade at lower or competitive costs;

- marginality of production-resource limitations caused by the factors just described and socioeconomic and geopolitical marginalization of mountain habitats;

- high levels of biological, cultural, climatic, and other diversity characteristic of mountains, which creates many special economic opportunities if properly harnessed and traded; and

- major known niche resources (hydropower, timber, NTFPs, minerals, eco-tourism, and so on) with comparative advantage to highlands.

The factors just outlined also help explain the persistence of poverty in many highland areas. Lowlands invest to harness highland opportunities largely for their own benefit. This has been helped by the unequal balance between highland and lowland people as trading partners and has resulted in generally unfavorable terms of trade for the highlands. Indeed, many export flows (both traded and non-traded) from mountains are neither appropriately priced nor fully compensated (Banskota and Sharma 1999).

The Earth Summit of 1992 in Rio de Janeiro signaled a new recognition of the critical importance of highland-lowland linkages and of the need for poverty and equity to be integrated in environmental management. The underpinnings of this increased awareness stem from four concerns regarding highland-lowland linkages: water shortages, together with growing demands for hydroelectricity in various parts of the world; warfare, which is disproportionately concentrated in mountain regions (Libiszewski and Bächler 1997); catastrophic events resulting from mismanagement of mountain resources (flash floods, massive flooding, and landslides); and climate change effects, including glacier retreat and loss of snowpack (Beniston 2000; Beniston et al. 1996).
Economic disparities between highland and lowland regions are closely related, either as cause or effect, to other key changes in mountain environments (described more fully in other sections), including migration, warfare, production of illegal drugs, risks and disasters, and climate change. These are noted here briefly, but only as related to the issue of linkages.

The problems of mountain-lowland population change are exemplified by trends in the Alps, where jobs and population are concentrating into a few favorable locations (transportation corridors and nodes). At the same time, the real alpine zone, with a few notable exceptions, is losing its productive potential (Bätzing et al. 1996) due to the loss of expert knowledge to manage landscapes in a traditional way. In terms of absolute numbers, however, out-migration is more than offset by amenity migration. This is causing problems in the mountains, where new migrants have different and often inappropriate land use practices, while migrants from mountains who settle in lowlands also face problems of adjustment and assimilation (Moss 1994; Price et al. 1997).

Armed conflict, guerrilla warfare, and extreme political unrest disproportionately affect mountain regions, both in terms of total surface area and in terms of populations. There is also widespread expression of political discontent among mountain (minority) peoples. Much of this conflict is attributed - either directly or indirectly - to the growing struggle for control of water (Libiszewski and Bächler 1997). Hewitt (1997) indicates that more than $70 \%$ of the almost 8 million war deaths in mountain lands since the end of World War II have been unarmed civilians. More recently, Starr (2004) supports this overall assessment, underscoring deeper linkages to poverty and inequity in mountains.

Mountain regions worldwide are frequently the source of illegal (and legal) narcotics: marijuana production in British Columbia in Canada; opium from the sizable remnant of the Golden Triangle, including Myanmar; hashish and heroin from Afghanistan; and cocaine from the central and northern Andean countries. These are effective cash crops for cultivators, and especially for the traders in the middle, because of the high market value and low weight. Some of the most dangerous places in the world for outsiders to visit are the drug-producing areas of the northern and central Andes. The level of hostile encounters there amounts to full-scale warfare; herbicide defoliation by military aircraft adds to the scale of environmental and human loss. The effects of downstream transfer of the toxic overflow are unknown. Certainly, the movement of the products takes on the guise of a singular highland-lowland interaction.

Mountain lands include regions of exceptional risk for human activities as well as some unique dangers. Earthquakes and volcanic eruptions are central to the processes of mountain building. Hewitt (1997) has argued that mountain peoples have experienced a pronounced disproportionate share of these disasters, whether this is calculated in terms of land area or population numbers. Mountain people also are deeply implicated in responsibility for some disasters as a result of their own management practices and are the disproportionate victims of inappropriate practices introduced by outsiders. Moreover, mountain regions lack access to emergency relief compared with lowland areas.

Climatological changes in mountain ranges are likely to have much more readily apparent impacts than in the surrounding lowlands. Winter recreation, availability of water, hydroelectricity, irrigation, and the sudden release of glacier lakes as glaciers continue to thin and retreat are all potential components.

Maximizing highland-lowland complementarities is crucial for both upstream and downstream communities. Healthy mountain communities require linkages to lowland markets, and lowland populations need mountain people to serve as stewards for 
upland resources and watersheds. Investments that favor such positive interactions are properly treated as transfer payments, not subsidies, and have a high potential to improve sustainability.

\subsubsection{Management and Interventions}

Chapter 13 of Agenda 21, adopted by governments in 1992, draws the attention of political authorities to the special issues facing mountain regions. Government structures to deal with mountain issues were called for, but as yet there are no government departments specifically for mountains, as there are for forestry or wildlife. Land, water, forest, environment, and development policies do not generally consider the challenges facing mountain regions, and organizational divisions make it particularly difficult to deal with the integrated, systems approaches needed. Nevertheless, with significant exceptions that are described here, existing management approaches have the potential to deal with most environmental problems specific to mountains.

Where biodiversity and scenic values are high and economically valuable commercial resources are inaccessible or limited (the "high biodiversity and low extractive value" situation described earlier), conservation interventions have proved valuable. Parks and protected areas help conserve water resources while providing scenic, aesthetic, and recreational value with considerable economic returns from tourism, as well as protection of investments in water supply for downstream populations. In some cases where formal conservation mechanisms are inappropriate (for example, due to high concentrations of upland settlements), interventions have nevertheless been designed to protect watersheds. Economic incentives for stewardship have potential for effective management, with transfer payments given in exchange for maintaining environmental services.

Where biotic resources are few, as in arid regions, and where commercial resources such as mineral ores are abundant (the "low biodiversity, high extractive value" case), regulatory approaches such as environmental impact assessments have been effective. However, successful interventions have been characterized by careful attention to implementing measures that avoid or mitigate adverse impacts and by social safety nets and revenue-sharing mechanisms designed and approved with active participation of local communities.

In a few regions, natural resources are so poor or degraded, and linkages to markets are so weak or nonexistent, that adequate management options have proved elusive. In these cases, downstream inhabitants receive few environmental services, but the size and cultural distinctness of mountain communities is such that it would be difficult to absorb any massive out-migrations. Here, governments have often justified welfare payments out of humanitarian concern, and such interventions have proved successful in achieving the limited goal of alleviating at least the extremes of hardship. More rarely, environmental restoration of such degraded lands has been attempted, albeit with varying results.

Management approaches have proved generally inadequate in two areas. The most important example is in mountain regions where both biological resources and commercially valuable extractive resources are significant and important. Standard management approaches, such as regulatory protections, have proved wholly inadequate, leaving almost all stakeholders frustrated. While environmental assessments are necessary, they are insufficient to deal with the complicated trade-offs involved, which require long time frames and mechanisms that permit continuing participation of all stakeholders. Such mechanisms and processes take more time than corporations and governments are generally comfortable with. And it has proved difficult to create "level playing fields" where local communities can negotiate on an equitable footing with national governments and private corporations. Nonetheless, providing the time and resources needed to address these highly complex situations is an urgent priority, as failure in such cases produces a disproportionate share of environmental damage in mountain regions.

A second area where interventions are lacking has to do with information for policy formulation and decision-making. In general, data are not currently collected on a spatial basis, making it difficult to "see" what needs to be done.

\subsection{Mountain Systems and Human Well-being}

\subsubsection{Sustainability}

This section is in part based on a background paper prepared for the World Development Report 2002/2003 (Pratt and Shilling 2002), but see also the recent Ambio Special Report (Sonesson and Messerli 2002).

Sustainable development has been defined as "development that meets the needs of the present without compromising the ability of future generations to meet their own needs" (WCED 1987). The fragility of mountain ecosystems represents a considerable challenge to sustainable development due to the fact that the impacts of unsustainable development are more rapid, heavier, and more difficult to correct than in other ecosystems. Arriving at a comprehensive definition of sustainability in mountains, particularly one that is universally accepted, is itself a mountainous task-and not likely to be a productive effort. More useful is to identify areas that merit protection and the characteristics and attributes that contribute to the sustainable use of mountain resources for human needs, broadly defined, for the alleviation of poverty, and for a more equitable allocation of resources and power.

Human activity in mountains that is not in balance with the environment can have serious consequences, resulting, for example, in soil erosion, pollution of natural waters, disruption of water and energy balances, elimination of both animal and plant species, loss of soil productivity, increasing food deficits, malnutrition and poor standards of living. Some of these consequences can be irreversible, such as the extinction of species and the loss of soil and cultural diversity.

In looking at sustainability, it is important to recognize that there are several time spans to consider. Short-term impacts would occur over the coming 20 years, medium-term impacts over 20-50 years, and long-term impacts over a longer horizon, extending to centuries or geological time spans. Our concerns should extend over both short and long time spans: while fires, landslides, and erosion can wipe out large areas of forest and other ecosystems in a very short period of time, it takes 50-100 years for a forest to regrow in mountainous areas, if it does so at all. Roads, mines, and other constructions last $20-50$ years and their impacts even longer, so decisions to undertake such activities have long-term implications.

Sustainability does not mean cessation of all change. Mountains are subject to continual natural change. They were created by massive geological forces and they are being torn down by natural forces of erosion and landslides. New species have evolved in mountains, and others have become extinct. The objective of promoting sustainability is therefore not to stop change in mountains but to manage resources in them in ways that provide livelihoods for people living there as well as the services valued in 
lowland areas - and to do so in ways that protect the long-term capacity of mountains to continue to provide such services.

In order to ensure sustainability in mountain areas it is necessary to reduce poverty, inequality, and marginality, to prevent deterioration of mountain natural resources and environments, and to improve the capabilities of institutions and organizations to promote conservation and sustainable mountain development. The goals are to:

- assure that people living in the mountains receive full benefit from their mountain resources so that poverty and inequity can be substantially reduced;

- preserve and enhance the long-term value of resources in mountains;

- eliminate or minimize disruptive, damaging, and polluting aspects of human interventions; and, most important,

- manage human-introduced change so that it generates benefits for current and future mountain inhabitants and for those living downstream.

Achieving environmental and human sustainability in mountains means finding ways to manage mountain resources and systems so that they can provide critical services indefinitely. While we cannot predict exactly what the future will look like or which services will be in demand, it is clear that mountains provide many essential services that will be valued for a long time and others that may increase in value (such as biological and cultural diversity, high-value forest products, and scenic beauty). Nearly all these values are tied to soil conservation - the alpha and omega of mountain integrity.

\subsubsection{Vulnerability}

This chapter has described how the vulnerability of mountain people has a variety of aspects and many different causes: availabil- ity of land; ownership of land; environmental constraints (climate, soils, slope, natural hazards); food insecurity; lack of access to markets, education, and health care; dependence on one single economic factor (such as only forests, livestock, or tourism); inappropriate governmental or industrial interventions; high specialization and interdependency of mountain social and land use systems; and globalization. Many elements of vulnerability are not well documented (but see Shrestha 2001 and Munir and Adhikari 2003), and there are few studies or statistics that quantify the number of mountain people vulnerable to these different elements. This discussion is based on a recent FAO study (Huddleston et al. 2003) and focuses on food insecurity, accessibility, and nutrient deficiencies.

Around $40 \%$ of mountain populations in developing and transition countries, or 271 million people, are estimated to be vulnerable to food insecurity, and of these, around half are likely to be chronically hungry. Most are rural people, with only 26 million of the vulnerable people living in mountain cities. An agriculturebased livelihoods approach has been used to locate and enumerate vulnerable people in rural mountain areas. Rural people living in areas where annual cereal production is less than 200 kilograms per capita and cattle numbers are small are considered vulnerable, as well as those living in closed forests. Work currently under way will extend the approach to cover other income sources in future vulnerability assessments. For instance, people living in protected areas can compensate through income from tourism if these monies are not channeled away to governmental agencies and operators, as is currently the case in most "trekking" destinations. However, they still remain very vulnerable in terms of food security, because tourism is unpredictable and may collapse over night.

Of the 245 million vulnerable mountain people living in rural areas, $87 \%$ live below 2,500 meters above sea level (classes 4, 5,

Table 24.13. Vulnerable Rural Mountain People in Developing and Transition Countries by Mountain Area Class. ${ }^{a}$ Based on LandScan 2000 Global Population Database. (Huddleston et al. 2003; mountain area classes, see Box 24.1)

\begin{tabular}{|c|c|c|c|c|c|c|c|}
\hline Region & $\begin{array}{l}300-1,000 \text { Meters } \\
\text { and Local } \\
\text { Elevation Range } \\
>300 \text { meters }\end{array}$ & $\begin{array}{l}1,000-1,500 \\
\text { Meters and Slope } \\
>5^{\circ} \text { or Local } \\
\text { Elevation Range } \\
>300 \text { Meters }\end{array}$ & $\begin{array}{c}1,500-2,500 \\
\text { Meters and } \\
\text { Slope }>2^{\circ}\end{array}$ & $\begin{array}{l}2,500-3,500 \\
\text { Meters }\end{array}$ & $\begin{array}{l}3,500-3500 \\
\text { Meters }\end{array}$ & $\begin{array}{l}>4,500 \\
\text { Meters }\end{array}$ & $\begin{array}{l}\text { Total for } \\
\text { Mountain }\end{array}$ \\
\hline & \multicolumn{7}{|c|}{ (million population) } \\
\hline Asia and the Pacific & 77.5 & 28.8 & 19.8 & 6.5 & 4.3 & 3.1 & 140.0 \\
\hline Latin America and Caribbean & 9.9 & 5.0 & 8.9 & 4.9 & 4.0 & 0.2 & 32.9 \\
\hline Near East and North Africa & 10.7 & 7.1 & 7.5 & 4.1 & 0.3 & 0.03 & 29.7 \\
\hline Sub-Saharan Africa & 10.6 & 10.6 & 7.3 & 2.2 & 0.09 & 0 & 30.9 \\
\hline Countries in transition & 7.7 & 1.9 & 1.0 & 0.4 & 0.2 & 0.02 & 11.2 \\
\hline $\begin{array}{l}\text { Total vulnerable in developing and } \\
\text { transition countries }\end{array}$ & 116.4 & 53.5 & 44.6 & 18.1 & 8.8 & 3.4 & 244.7 \\
\hline $\begin{array}{l}\text { Total rural mountain population in } \\
\text { developing and transition countries }\end{array}$ & 241.6 & 98 & $\begin{array}{l}104.8 \\
\text { (percent) }\end{array}$ & 31.6 & 10.1 & 4.1 & 490.3 \\
\hline $\begin{array}{l}\text { Vulnerable in class as share of rural } \\
\text { mountain population in class }\end{array}$ & 48 & 55 & 43 & 57 & 87 & 82 & \\
\hline $\begin{array}{l}\text { Vulnerable in class as share of total } \\
\text { vulnerable }\end{array}$ & 48 & 22 & 18 & 7 & 4 & 1 & 100 \\
\hline
\end{tabular}


and 6), where they represent less than half of the mountain population at lower altitudes. (See Table 24.13.) With more than three quarters of mountain populations in developing and transition countries still classified as rural, the performance of agriculture is a crucial factor in determining the degree of their vulnerability to food insecurity. As described earlier in this chapter, pastoral systems are very important for mountain people at all elevations in developing and transition countries. At the present time, these systems are becoming increasingly vulnerable as populations grow, livestock numbers increase, the quality of pasture and browse declines, and the incidence of drought becomes more frequent and its impacts more severe.

In high mountain areas, the absolute number of vulnerable rural people is small, but they represent almost $70 \%$ of the population living above 2,500 meters, and many live in extreme poverty. The higher prevalence of vulnerability at higher elevations and the importance of these areas for the overall sustainability of mountain ecosystems warrant particular attention.

It is generally accepted that mountain people live in remote, isolated areas that are poorly served by physical infrastructure and social services. In Ethiopia, for instance, about half of the mountain population and $40 \%$ of the non-mountain population live more than 5 kilometers from roads. In Afghanistan and China, the figure for mountain people is around one third and for nonmountain people, about $20 \%$. In Peru, however, just $20 \%$ of mountain people and $13 \%$ of non-mountain people live more than 5 kilometers from a road (Huddleston et al. 2003).

In 33 of the 40 mountainous developing countries covered by the FAO report (Huddleston et al. 2003), there has been an increase in malnutrition as the proportion of mountain people has increased, measured by the prevalence of vitamin $\mathrm{A}$, iron, and iodine deficiencies (globally the most significant micronutrient deficiencies in children). There are also significant differences in the distribution of micronutrient deficiencies across regions. Vitamin A deficiency is particularly common in mountainous countries of eastern and southern Africa, where consumption of fruits and vegetables that are rich in vitamin $A$ is low; iodine deficiency is particularly prevalent in the Himalaya, where the soils have been leached of their iodine-carrying salts; and iron deficiency is common across all regions, though with somewhat greater incidence in sub-Saharan Africa.

\section{References}

Association des populations des montagnes du mond., 2003: Quito Declaration-Charter for World Mountain People. 20 September 2002, Quito, Ecuador. Available at http://www.mtnforum.org/resources/library/ dcwmp03a.htm.

Bandyopadhyay, J., 1997: Chipko-a unique movement of mountain people for sustainability. In: Mountains of the World-A Global Priority, B. Messerli and J.D. Ives (eds.). Parthenon Publishing Group, New York, London, pp. 127-128.

Bandyopadhyay, J. and V. Shiva, 1985: Conflict over limestone quarrying in Doon Valley, Himalaya. Environmental Conservation, 12(2): 1319.

Baron, J.S., H.M. Rueth, A.M. Wolfe, K.R. Nydick, E.J. Allstott, et al. 2000: Ecosystem responses to nitrogen deposition in the Colorado Front Range. Ecosystems 3: 352-368.

Barry, R.G., 1992: Mountain Weather and Climate. 2nd ed, Routledge, London.

Bartholome, E. M. and A. S. Belward, 2004 (in press): GLC2000, a new approach to global land cover mapping from earth observation data. International Journal of Remote Sensing.

Banskota, K. and B. Sharma, 1999: Traded Resource Flows from Highland to Lowland: Understanding Economic Linkages. ICIMOD, Kathmandu, 99 pp.

Battarbee, R.W., J.A. Grytnes, R. Thompson, P.G. Appleby, J. Catalan, et al. 2002: Comparing paleolimnological and instrumental evidence of climate change for remote mountain lakes over the last 200 years. Journal of Paleolimnology, 28: 161-179.
Bätzing, W., M. Perlik, and M. Dekleva, 1996: Urbanization and depopulation in the Alps. Mountain Research and Development, 16: 335-350.

Beall, C.M., 2002: Human dimensions of global mountain biodiversity. In: Mountain Biodiversity. A global assessment. C. Körner, and E.M. Spehn (eds.), Parthenon Publishing Group, London, New York, 199-210 pp.

Beniston, M., D.G. Fox, S. Adhikary, R. Andressen, A. Guisan, et al. 1996: The impacts of climate change on mountain region. Second assessment report of the Intergovernmental Panel on Climate Change (IPCC), Chapter 5. Cambridge University Press, pp. 191-213.

Beniston, M., 2000: Environmental Change in Mountains and Uplands. Oxford University Press, London, 172 pp.

Beniston, M. and M. Rebetez, 1996: Regional behaviour of minimum temperatures in Switzerland for the period 1979-1993. Theor. Appl. Climatol., 53, 231-243.

Beniston, M., F. Keller, and S. Goyette, 2003: Snow pack in the Swiss Alps under changing climatic conditions: an empirical approach for climate impact studies. Theor. Appl. Climatol., 74, 19-31.

Berkes, F. and Folke, C., 2002: Back to the Future: Ecosystem dynamics and local knowledge, In: Panarchy: Understanding Transformations in Human and Natural Systems. Gunderson, L.H. and Holling, C.S. (eds.), Island Press, Washington: 121-146.

Bernbaum, E., 1998: Sacred Mountains of the World. University of California Press, Berkeley, Los Angeles, London, 291 pp.

Black, H.C., 1990: Black's Law Dictionary. Sixth Edition, West Publishing, St.Paul, Minn.

Blais, J.M., D.W. Schindler, D.C.G. Muir, D.B. Donald, and B. Rosenberg, 1998: Accumulation of persistent organochlorines in mountains of western Canada. Nature 395: 585-588.

Blais, J.M., D.W. Schindler, D.C.G. Muir, M. Sharp, D. Donald, et al. 2001: Glaciers are a dominant source of persistent organochlorines to a subalpine lake in Banff National Park, Canada. Ambio 30: 410-415.

Bocco, G., M. Mendoza and A. Velázquez, 2001: Remote sensing and GISbased regional geomorphologic mapping - A tool for land use planning in developing countries. Geomorphology, 39, 211-219.

Bormann, F.H. and Likens, G.E. 1979: Pattern and Process in a Forested Ecosystem. Disturbance, Development and the Steady State Based on the Hubbard Brook Ecosystem Study. Springer, Berlin, New York, 253 pp.

Brown, S., A.J.R. Gillespie, and A.E. Lugo, 1991: Biomass of tropical forests of South and Southeast Asia. Canadian Journal of Forest Research, 21, 111-117.

Bruijnzeel, L. A. and J. Proctor. 1995: Hydrology and biochemistry of tropical montane cloud forests: What do we really know? In: Tropical Montane Cloud Forests. Hamilton, L. S., J. O. Juvik and F. N. Scatena (eds.). Springer Verlag, New York, Berlin pp. 38-78.

Buck, S., 1996: Understanding Environmental Administration and Law. Island Press, Washington DC.

Callaway, R.M., Kikvidze, Z., and Kikodze, D. 2000: Facilitation by unpalatable weeds may conserve plant diversity in overgrazed meadows in the Caucasus Mountains. Oikos 89, 275-282.

Cassells, D. 1996: Review of the Watershed Management Component of the Natural Resources Management Project, Colombia. Internal Document. The World Bank, Washington, DC.

CIESIN (Center for International Earth Science Information Network), Columbia University, and Centro Internacional de Agricultura Tropical, 2004a: Gridded population of the world (GPW), version 3. CIESIN, Columbia University, Palisades, NY. Available at http://sedac.ciesin.columbia.edu/gpw.

CIESIN, Columbia University, International Food Policy Research Institute, World Bank, and Centro Internacional de Agricultura Tropical, 2004b: Global rural-urban mapping project (GRUMP), version 1 alpha: gridded population of the world (GPW), version 3, with urban reallocation. CIESIN, Columbia University, Palisades, NY. Available at http://sedac.ciesin.columbia.edu/gpw.

Chape, S., S. Blyth, L. Fish, P. Fox, and M. Spalding, 2003: 2003 United Nations List of Protected Areas. IUCN/UNEP-WCMC, Cambridge, $27 \mathrm{pp}$.

Commission on Sustainable Development, 1995: Economic and Social Council Official Records, Supplement No. 12 in the CSD report on the third session, 11-28 April 1995. United Nations, New York.

Conservation International, 1999: Valuation of Mt. Gede-Pangrango National Park, Natural Resource Management Program. Conservation International (Indonesia), Jakarta.

CONITE (Comisión Nacional para la Inversión y Technología Extranjera), 1999: Boletín Estadístico. Lima, Perú.

Cuatrecasas, J. 1986: Speciation and radiation of the Espeletiinae in the Andes. In: High Altitude Tropical Biogeography, Vuilleumier, F. and Monasterio, M. (eds.), Oxford Univ. Press, New York, pp. 267-303. 
Daniggelis, E., 1997: Hidden Wealth. The Survival Strategy of Foraging Farmers in the Upper Arun Valley, Eastern Nepal. Mandala Book Point \& The Mountain Institute, $261 \mathrm{pp}$.

Dhar, U. (ed.), 1997: Himalayan Biodiversity - An Action Plan. The G.B. Pant Institute of Himalayan Environment and Development, Almora, India, 136 pp.

Diaz, H.F. and N.E. Graham, 1996: Recent changes of tropical freezing heights and the role of sea surface temperature. Nature 383, 152-155.

Diaz, H.F and R.S. Bradley, 1997: Temperature variations during the last century at high elevation sites. Climatic Change, 36(3-4), 253-279.

Dixon, J., A. Gulliver, and D. Gibbon, 2001: Farming Systems and Poverty, Improving Farmer's Livelihoods in a Changing World. FAO and World Bank, $420 \mathrm{pp}$.

Donald, D.B., Vinebrooke R.D., R.S. Anderson, J. Syrgiannis, M.D. Graham, 2001: Recovery of zooplankton asssemblages in mountain lakes from the effects of introduced sport fish. Canadian Journal of Fisheries and Aquatic Sciences, 58, 1822-1830.

Dorji, K., 2000: Biodiversity Assessment and Conservation Planning Bhutan. WWF Bhutan Program.

Dudley, N. and S. Stolton, 2003: Running Pure: The Importance of Forest Protected Areas to Drinking Water. World Bank/WWF Alliance for Forest Conservation and Sustainable Use, Washington, D.C., 114 pp.

Easter, K.W. and M.M. Hufschmidt, 1985: Integrated Watershed Management Research for Developing Countries. East West Center Workshop Report. Honolulu.

FAO (Food and Agriculture Organization of the United Nations), 2001: Global Forest Resources Assessment 2000. FAO Forestry Paper 140, Rome, 512 pp.

FAO, 2002a: International Year of the Mountains. Food and Agriculture Organisation of the United Nations, Rome.

FAO, 2002b: Land-water linkages in rural watersheds. Land and Water Bulletin 9. Food and Agriculture Organisation of the United Nations, Rome, $88 \mathrm{pp}$.

FAO, 2003: State of the World's Forests 2003. Food and Agriculture Organisation of the United Nations, Rome, $168 \mathrm{pp}$.

FAO, 2004: Payment schemes for environmental services in watersheds. Land and Water Discussion Paper 3. Food and Agriculture Organisation of the United Nations, Rome.

FAO/REDLACH, 2004: Foro electrónico sobre Sistemas de Pago por Servicios Ambientales en Cuencas. Informe final. Available at http://www.rlc.fao.org/foro/ psa/

Gentry, A.H., 1988: Changes in plant community diversity and floristic composititon on environmental and geographical gradients. Ann. Missouri Bot. Gard., 75, 1-34.

Gorbunov, A.P., S.S. Marchenko, and E.V. Seversky, 2000: Permafrost and seasonally frozen ground response to climate changes in the northern Tien Shan. Krisfera Zemli, 4, 11-17.

Gottfried, M., H. Pauli, K. Reiter, and G. Grabherr, 1999: A fine-scaled predictive model for changes in species distributions patterns of high mountain plants induced by climate warming, Diversity and Distributions, 5: 241-251.

Grabherr, G., M. Gottfried, and H. Pauli, 1994: Climate effects on mountain plants. Nature 369: 448.

Grimalt, J.O., Fernandez, P., Berdie, L., Vilanova, R.M., Catalan, et al. 2001: Selective trapping of organochlorine compounds in mountain lakes of temperate areas. Environ. Sci. Technol., 35: 2690-2697.

Gurtz, J., M. Zappa, K. Jasper, H. Lang, M. Verbunt, A. Badoux and T. Vitvar, 2003: A comparative study in modelling runoff and its components in two mountainous catchments. Hydrol. Process, 17(2), 297-311.

Haeberli, W. and M. Beniston, 1998: Climate change and its impacts on glaciers and permafrost in the Alps. AMBIO, 27(4): 258-265.

Hamilton, L. S. (with P.A. King), 1983: Tropical Forested Watersheds; Hydrologic and Soils Response to Major Uses or Conversions. Westview Press, Boulder, Colorado.

Hamilton, L.S. and L.A. Bruinjzeel, 1997: Mountain watersheds integrating water, soils, gravity, vegetation, and people. In: Mountains of the World-A Global Priority. B. Messerli and J.D. Ives (eds.). Parthenon Publishing Group, New York, London, 337-370.

Hamilton, L.S. and L. McMillan (eds.), 2004: Guidelines for Planning and Managing Mountain Protected Areas. IUCN, Gland, Switzerland and Cambridge, UK

Hamilton, L.S., J.C. Mackay, G.L. Worboys, R.A. Jones, and G.B. Manson, 1996: Transborder Protected Area Cooperation. IUCN/Australian Alps National Parks, Canberra.

Handa, T., C. Körner, and S. Haettenschwiler, in press: Atmospheric $\mathrm{CO}_{2}$ enrichment and defoliation: manipulating the carbon balance of alpine conifers at treeline. Ecology.
Hewitt, K., 1997: Risk and disasters in mountain lands. In: Mountains of the World - A Global Priority. B. Messerli and J.D. Ives (eds.). Parthenon Publishing Group, New York, London, pp. 371-408.

Hofstede, R.G.M., M.X. Mondragón Castillo, and C.M. Rocha Osorio, 1995: Biomass of grazed, burned and undisturbed Páramo grasslands, Colombia. I. Aboveground vegetation. Arctic Alpine Research, 27, 1-12.

Hofstede, R.G.M., J.P. Groenendijk, R. Coppus, J. Fehse, and J. Sevink, 2002: Impact of pine plantations on soils and vegetation in the Ecuadorian high Andes. Mountain Research and Development, 22(2): 159-167.

Huddleston, B., E. Ataman, and L. Fe d'Ostiani, 2003: Towards a GIS-based analysis of mountain environments and populations. Environment and Natural Resources Working Paper, No. 10. Food and Agriculture Organisation of the United Nations, Rome.

IUCN (World Conservation Union), 2000: Guidelines for Protected Area Management Categories: interpretation and application of the protected area management categories in Europe. 2nd edition. IUCN, EUROPARC Federation, IUCN World Commission on Protected Areas, WCMC, Grafenau: EUROPARC, $46 \mathrm{pp}$.

Jenkins, A. 2002: The sensitivity of headwater streams in the Hindu Kush Himalayas to acidification. Water, Air, and Soil Pollution: Focus 2,181-189.

Jodha, N.S. 2000: Globalisation and Fragile Mountain Environments-Policy Challenges and Choices. Mountain Research and Development, 20(4): 296-299.

Jodha, N.S., 2001: Sustainable agriculture in fragile resource zones: technological imperatives. In: Life on the Edge: Sustaining Agriculture and Community Resources in Fragile Environments, N.S. Jodha (ed.), Oxford University Press, New Delhi.

Jodha, N.S., 2002: Rapid Globalisation and Fragile Mountains: Sustainability and Livelyhood Security Implications in Himalayas. Final narrative report of the research planning project submitted to the MacArthur Foundation, ICIMOD, Kathmandu, Nepal.

Kaeaeb, A., Reynolds, J.M. and Haeberli, W. 2005: Glacier and permafrost hazards in high mountains. In: Global change in mountain regions: a state of knowledge overview, Huber, U., Reasoner M. and Bugmann, H. (eds.), Springer, Dordrecht, pp. 225-234.

Kapos, V., J. Rhind, M. Edwards, M.F. Price and C. Ravilious, 2000: Developing a map of the world's mountain forests. In: Forests in Sustainable Mountain Development: A State-of-Knowledge Report for 2000, M.F. Price and N. Butt (eds.), CAB International, Wallingford: 4-9.

Körner, C., 1989: Der Flächenanteil unterschiedlicher Vegetationseinheiten in den Hohen Tauern: Eine quantitative Analyse grossmassstäblicher Vegetationskartierungen in den Ostalpen. In: Struktur und Funktion von Graslandökosystemen im Nationalpark Hohe Tauern, Cernusca, A. (ed), Wagner, Innsbruck, Veröffentl Oesterr MaB-Programm, 13: 33-47.

Körner, C., 1995: Alpine plant diversity: a global survey and functional interpretations. In: Arctic and Alpine Biodiversity: Patterns, Causes and Ecosystem Consequences, F.S. Chapin III, and C. Körner (eds.), Ecological Studies 113, Springer, Berlin, pp. 45-62.

Körner, C., M. Diemer, B. Schappi, P.A. Niklaus, and J. Arnone, 1997: The responses of alpine grassland to four seasons of $\mathrm{CO}_{2}$ enrichment: a synthesis. Acta Oecologia International Journal of Ecology, 18: 165-175.

Körner, C., 2000: Why are there global gradients in species richness? Mountains might hold the answer. Trends in Ecology and Evolution. 15: 513-514

Körner, C. and E.M. Spehn (eds.), 2002: Mountain Biodiversity. A Global Assessment. Parthenon Publishing Group, London, New York.

Körner C, 2003: Alpine Plant Life. Springer, Berlin. 2nd edition.

Körner, C. and J. Paulsen, 2004: A world-wide study of high altitude treeline temperatures. Journal of Biogeography, 31, 713-732.

Körner, C., 2004: Mountain biodiversity, its causes and function. Ambio, 33, in press.

Li, X., and L. Sun, 1997: Driving forces of arable land conversion in China. International Institute for Applied Systems Analysis (IIASA). Available at http:// www.iiasa.ac.at/cgi-bin/pubsrch?IR 97076.

Libiszewski, S. and G. Bächler, 1997: Conflicts in mountain areas—a predicament for sustainable development. In: Mountains of the World-A Global Priority. B. Messerli and J.D. Ives (eds.). Parthenon Publishing Group, New York, London, pp. 103-130.

Liniger, H.P., R. Weingartner, M. Grosjean, C. Kull, L. MacMillan, et al., 1998: Mountains of the World, Water Towers for the 21st Century-A Contribution to Global Freshwater Management. Mountain Agenda, Paul Haupt, Bern, 28 pp.

Lowenthal, D., 1985: The Past is a Foreign Country. Cambridge University Press, Cambridge.

Lynch, O.J. and G.F. Maggio, 2000: Mountain Laws and Peoples: Moving towards sustainable development and recognition of community-based property rights. The 
Mountain Insititue and Center for International Environmental Law. Washington, D.C.

Messerli, B. and H. Hurni, 2000: African Mountains and Highlands: Problems and Perspectives. African Mountains Association, Walsworth Press, Missouri.

Morris, A., 1997: Afforestation projects in highland Ecuador: patterns of success and failure. Mountain Research and Development, 17(1): 31-42.

Moss, L.A.G.. 1994: Beyond tourism: the amenity migrants. In: Chaos in our Uncommon Futures, Mannermaa, M., Inayatullah, S. and Slaughter, R. (eds.), University of Economics, Turku, 121-128.

Munir, S. and K. Adhikari, 2003: Globalisation and Mountain Farmers: Tapping opportunities and mitigating threats. Synthesis Report, $v+41$, South Asia Watch on Trade, Economics \& Environment (SAWTEE), Kathmandu, 47 pp.

Nagy, L., G. Grabherr, C. Körner, D.B.A. Thompson (eds.), 2003: Alpine Biodiversity in Europe. Ecological Studies 167, Springer, Berlin, Heidelberg, New York.

O'Loughlin, D. L. and R. R. Ziemer, 1982: The importance of root strength and deterioration rates upon edaphic stability in steepland forests. In: Carbon Uptake and Allocation: A Key to Management of Subalpine Ecosystems, R. H. Waring (ed.), Oregon State University, Corvallis, Oregon, pp. 70-78.

Olson, D.M., E. Dinerstein, E.D. Wikramanayake, N.D. Burgess, G.V.N. Powell, et al., 2001: Terrestrial ecoregions of the world: a new map of life on earth. BioScience, 51(11), 933-938.

Ohsawa, M., 1990: An interpretation of latitudinal patterns of forest limits in South and East Asian mountains. Journal of Ecology, 78: 326-339.

Ohsawa, M., 1995: Latitudinal comparison of altitudinal changes in forest structure, leaf type, and species richness in humid monsoon Asia. Vegetatio, 121: 3-10.

Pauli, H., M. Gottfried, D. Hohenwallner, K. Reiter, R. Casale, and G. Grabherr (eds.), 2004: The GLORIA (Global Observation Research Initiative in Alpine Environments) Field Manual-Multi-Summit Approach. European Commission, Directorate-General for Research, EUR 21213, Office for Official Publications of the European Communities, Luxembourg.

Pauli, H., M. Gottfried, D. Hohenwallner, K. Reiter, and G. Grabherr, 2005 (in press): Ecological climate impact research in high mountain environments: GLORIA (Global Observation Research Initiative in Alpine Environments) - its roots, its purpose and the long-term perspectives. In: Global change in mountain regions: a state of knowledge overview, Huber, U., Reasoner M. and Bugmann, H. (eds.), Springer, Dordrecht, pp. 377-386.

Pepin, N. 2000: Twentieth-century change in the climate record for the Front Range, Colorado, USA. Arct. Antarct. Alp. Res. 32(2), 135-146.

Peterken, G.F. 1981: Woodland Conservation and Management. Chapman \& Hall.

Peterson, A.T., V.O.A. Flores, P.L.S. Leon, B.J.E. Llorente, M.M.A. Luis, S.A.G. Navarro, C.M.G. Torres, and F.I. Vargas, 1993: Conservation priorities in Northern Middle America: Moving up in the world. Biodiversity Letters 1: $33-38$.

Pratt, D. J. (ed.), 1998: Sacred Mountains and Environmental Conservation, A Practitioner's Workshop. The Mountain Institute, West Virginia.

Pratt, D. J., 2001: Corporations, Communities, and Conservation. California Management Review, Vol. 43, No. 3, Haas School of Business, University of California Press, Berkeley.

Pratt, D. J. and J. Shilling, 2002: High Time for Mountains. Background paper prepared for the World Development Report 2002/2003. World Bank, Washington DC

Preston, D., 1996: Latin America Development: Geographical Perspectives. Longman Scientific \& Technical, Harlow, England, 165-187.

Price, M.F., L.A.G. Moss, and P.W. Williams, 1997: Tourism and amenity migration. In: Mountains of the World-A Global Priority, B. Messerli and J.D. Ives (eds.). Parthenon Publishing Group, New York, London, pp. 249-280.

Price, M., 1999: Global Change in the Mountains. Parthenon, New York, 217 pp.

Ramankutty, N., and J.A. Foley, 1999: Estimating historical changes in global land cover: croplands from 1700 to 1992. Global Biogeochemical Cycles, 13(4), 997-1027.

Rasmussen, S.F. and S. Parvez, 2004: Sustaining mountain economies: sustainable livelihoods and poverty alleviation. In: Key issues for Mountain Areas, M.F Price, L. Jansky, and A.A. Iatsenia (eds.), United Nations University Press, Tokyo.

Rodgers, W.A., 2002: Development Contradictions. In: Kilimanjaro: The Story of A Mountain. National Geographic Press, Washington. DC, pp 230-231.

Rognerud, S., J.O. Grimalt, B.O. Rosseland, P. Fernandez, R. Hofer, et al., 2002: Mercury and organochlorine contamination in brown trout (Salmo trutta) and arctic charr (Salvelinus alpinus) from high mountain lakes in Europe and the Svalbard archipelago. Water, Air, and Soil Pollution: Focus 2: 209-232.
Schimel, D., Kittel T.G.F., Running S., Monson R., Turnipseed A. and D.Anderson, 2002: Carbon sequestration studied in Western US Mountains. EOS, 83: $445-449$

Schindler, D.W. 1999: From acid rain to toxic snow. Ambio 28(4): 350-355.

Schindler, D.W. and B.R. Parker, 2002: Biological pollutants: aline fishes in mountain lakes. Water, Air, and Soil Pollution: Focus 2: 379-397.

Shrestha, A.B., C.P. Wake, P.A. Mayewski and J.E. Dibb, 1999: Maximum temperature trends in the Himalayas and its vicinity: An analysis based on temperature records from Nepal for the period 1971-1994. Journal of Climate, 12, 2775-2786.

Shrestha, K.L., 2001: Global change and the Himalayan mountain ecosystem. In: Global Change and Himalayan Mountains, K.L. Shrestha (ed.), Proceedings of a Scoping Workshop, Kathmandu, Nepal, 2-5 October 2001, Institute for Development and Innovation, Lalitpur, Nepal.

Sommaruga-Wögrath, S., K.A. Koinig, R. Schmidt, R. Sommaruga, R. Tessadri, and R. Psenner, 1997: Temperature effects on the acidity of remote alpine lakes. Nature 387:64-67.

Sonesson, M. and B. Messerli (eds.), 2002: The Abisko Agenda: Research for mountain area development. Rethinking Agenda 21, Chapter 13: Managing fragile ecosystems. A contribution to the United Nations Year of Mountains 2002. Ambio Special Report, 11, 1-105.

Spreafico, M., 1997: Without mountains there is no life in the Aral basin. In: Mountains of the World, B. Messerli and J.D. Ives (eds.), Parthenon, London, 145.

Spehn, E.M., M. Libermann, and C. Körner (eds.), 2005 (in press): Land use change and mountain biodiversity. CRC Press, Boca Raton.

Starr, S.F., 2004: Conflict and peace in mountain societies. In: Key Issues for Mountain Areas, M.F Price, L. Jansky, and A.A. Iatsenia (eds.), United Nations University Press, Tokyo, 169-180.

Tang, C.Q. and M. Ohsawa, 2002: Tertiary relic deciduous forests on a humid subtropical mountain, Mt. Emei, Sichuan, China. Folia Geobotanica, 37, 93106.

The Mountain Institute, 1998: Community Based Mountain Tourism, Practices for Linking Conservation with Enterprise. Synthesis of a Mountain Forum Electronic Conference in Support of the Mountain Agenda. Washington, DC.

Theurillat, J.-P., and A. Guisan, 2001: Potential impact of climate change on vegetation in the European Alps: A review. Climatic Change, 50, 77-109.

Thompson, L.G., E. Mosley-Thompson, M. Davis,P.N. Lin, T. Yao, M. Dyurgerov, and J. Dai, 1993: Recent warming: Ice core evidence from tropical ice cores with emphasis on central Asia. Global Planet. Change, 7, 145-56.

Thorsell, J., 1997: Protection of nature in mountain regions. In: Mountains of the World-A Global Priority. B. Messerli and J.D. Ives (eds.). Parthenon Publishing Group, New York, London, pp 237-248.

Thorsell, J. and L. S. Hamilton, in press: A global overview of mountain protected areas on the world Heritage list. In: Managing Mountain Protected Areas in the 21st Century, D. Harmon and G. Worboys (eds.). Andromeda Editrice, Colledara, Italy.

Udvardy, M.D.F., 1975: A classification of the biogeographical provinces of the world. Occasional Paper No. 18., IUCN, Morges, Switzerland.

UNEP (United Nations Environment Programme), 2002: Global Environment Outlook 3. Past, present and future perspectives. GEO-3. Earthscan, London.

UNEP-WCMC (World Conservation Monitoring Centre), 2002: Mountain Watch: environmental change $\mathcal{E}$ sustainable development in mountains. Cambridge, UK.

UNEP-WCMC, 2003: Mountains derived from U.S. Geological Survey National Mapping Division, EROS Data Center (EDC), 1996: Global 30 Arc Second Elevation Data (GTOPO 30), and Forests derived from UNEPWCMC's global forest cover dataset, an update of Iremonger, S. Ravilious, C. and Quinton, T. (eds.), 1997: A global overview of forest conservation. Available at: <http://www.unep-wcmc.org/habitats/mountains/statistics.htm.>

UNCED (United Nations Conference on Environment and Development), 1992: Agenda 21. The United Nations Programme of Action from Rio. The final text of agreements negotiated by governments 3-14 June 1992, Rio de Janeiro, Brazil. 294 pp.

van der Knaap, W.O. and J.F.N van Leeuwen, 1995: Holocene vegetation succession and degradation as responses to climatic change and human activity in the Serra da Estrela, Portugal. Review of Palaeobotany and Palynology, 89, 153-211.

Velázquez, A., G. Bocco, F.J. Romero, and A.P. Vega, 2003: A landscape perspective on biodiversity conservation. Mountain Research and Development, 23(3), 240-246.

Vinebrooke, R.D. and P.R. Leavitt, 1998: Direct and interactive effects of allochthonous dissolved organic matter, inorganic nutrients, and ultraviolet 
radiation on an alpine littoral food web. Limnology and Oceanography, 43,1065-1081.

Vinebrooke, R.D. and P.R. Leavitt, 1999: Phytobenthos and phytoplankton as bioindicators of climate change in mountain lakes and ponds: an HPLCbased approach. Journal of the North American Benthological Society, 18,14-32.

Viviroli, D., R. Weingartner, and B. Messerli, 2003: Assessing the hydrological significance of the world's mountains. Mountain Research and Development, 23(1), 32-40.

Vonder Mühll, D.S., T. Stucki, and W. Haeberli, 1998: Borehole temperatures in alpine permafrost: a ten-year series. In: Proceedings, The 7th International Permafrost Conference, A.G. Lewcowitz and M. Allard (eds.), University of Laval, Quebec, pp. 1089-95.

Vuille, M. and R.S. Bradley, 2000: Mean annual temperature trends and their vertical structure in the tropical Andes. Geophysical Research Letters, 27(23), 3885-3888.

Wardle, P., 1971: An explanation for alpine timberline. New Zealand Journal of Botany, 9, 371-402.
WCED (World Commission on Environment and Development), 1987: Our Common Future. Oxford University Press, Oxford.

Whiteman, P.T.S., 1998: Mountain agronomy in Ethiopia, Nepal and Pakistan. In: Human Impacts on Mountains. N.J. R. Allan, G.W. Knapp and C. Stadel (eds.), Rowman and Littlefield, Totowa, New Jersey,pp. 57-82.

Yirdaw, E., 2001: Restoration of biodiversity on degraded lands in Ethiopia through the use of forest plantations. In: World forests, markets and policies. World Forests, Society and Environment III, M. Palo, J. Uusivuori and G. Mery (eds.), Kluwer Academic Publishers, The Netherlands, pp. 337-338.

Yoshino, M., 1975: Climate in a small area. Tokyo, University of Tokyo Press. Yoshino, M., 2002: Global warming and mountain environment. Paper presented at the Symposium on International Year of Mountains held at the United Nations University on 1 Feb., 2002.

Zbicz, D., 2001: Global list of complexes of internationally adjoining protected areas. Appendix 1. In: Transboundary Protected Areas for Peace and Co-operation, Sandwith, T., C. Shine, L. Hamilton and D. Sheppard (eds.), WCPA/IUCN with Cardiff University: Gland and Cambridge, pp. 55-75. 